In cooperation with the Ohio Environmental Protection Agency

\title{
Simulation of Streamflow and Water Quality to Determine Fecal Coliform and Nitrate Concentrations and Loads in the Mad River Basin, Ohio
}

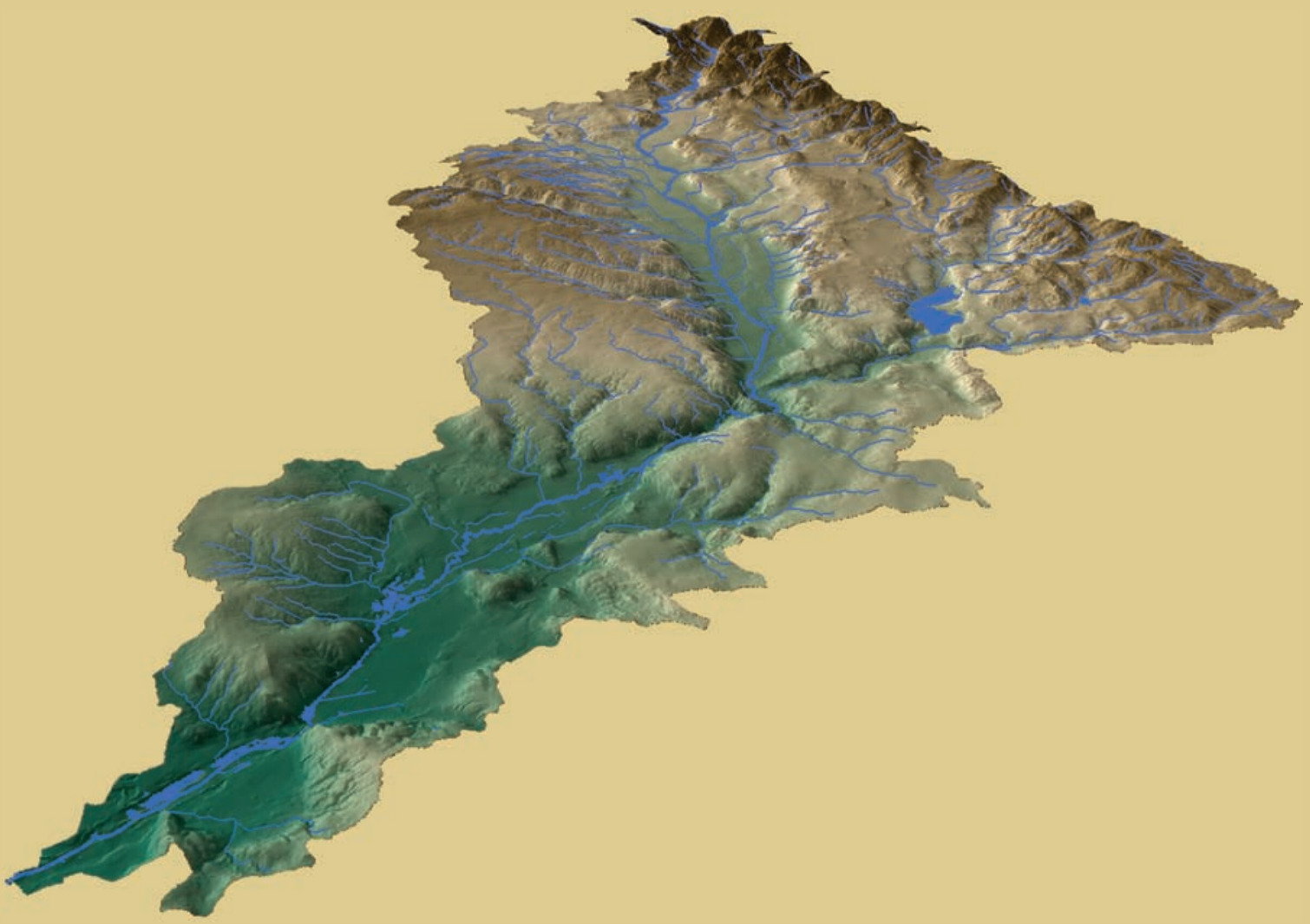

Scientific Investigations Report 2006-5160 
COVER IMAGE: Computer-generated three-dimentional perspective view of the Mad River Basin looking northward. Prepared by Barry M. Puskas, U.S. Geological Survey. 


\section{Simulation of Streamflow and Water Quality to Determine Fecal Coliform and Nitrate Concentrations and Loads in the Mad River Basin, Ohio}

By David C. Reutter, Barry M. Puskas, and Martha L. Jagucki

In cooperation with the Ohio Environmental Protection Agency

Scientific Investigations Report 2006-5160 


\section{U.S. Department of the Interior DIRK KEMPTHORNE, Secretary \\ U.S. Geological Survey \\ P. Patrick Leahy, Acting Director}

\section{U.S. Geological Survey, Reston, Virginia: 2006}

For product and ordering information:

World Wide Web: http://www.usgs.gov/pubprod

Telephone: 1-888-ASK-USGS

For more information on the USGS — the Federal source for science about the Earth, its natural and living resources, natural hazards, and the environment:

World Wide Web: http://www.usgs.gov

Telephone: 1-888-ASK-USGS

Any use of trade, product, or firm names in this publication is for descriptive purposes only and does not imply endorsement by the U.S. Government.

Although this report is in the public domain, permission must be secured from the individual copyright owners to reproduce any copyrighted materials contained within this report.

Suggested citation:

Reutter, D.C., Puskas, B.M., and Jagucki, M.L., 2006, Simulation of streamflow and water quality to determine fecal coliform and nitrate concentrations and loads in the Mad River Basin, Ohio: U.S. Geological Survey Scientific Investigations Report 2006-5183, 93 p. 


\section{Contents}

Abstract

Introduction

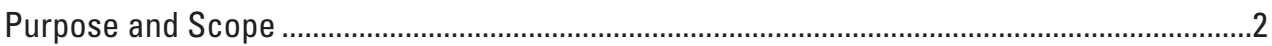

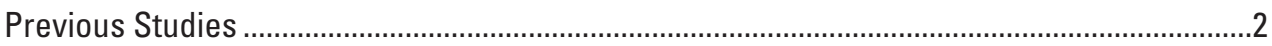

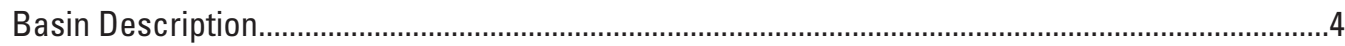

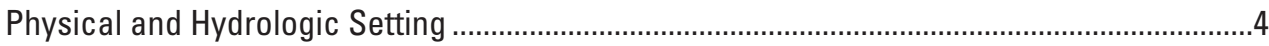

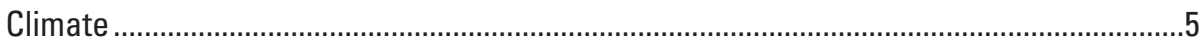

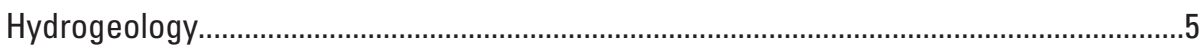

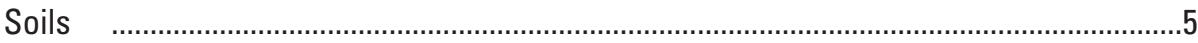

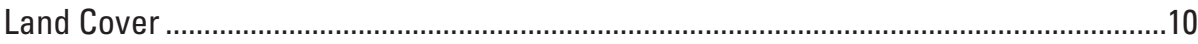

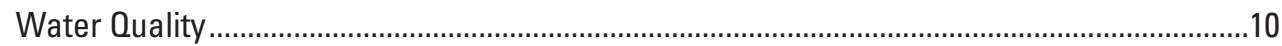

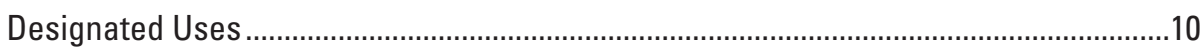

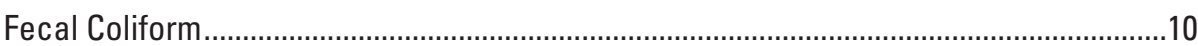

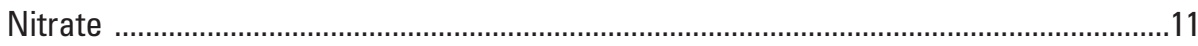

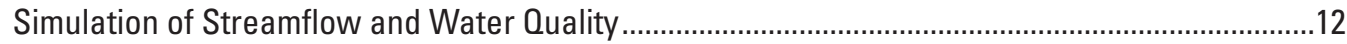

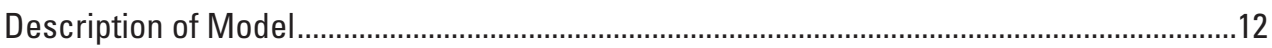

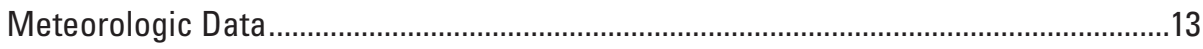

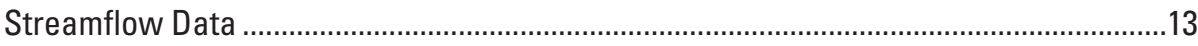

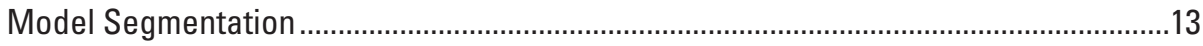

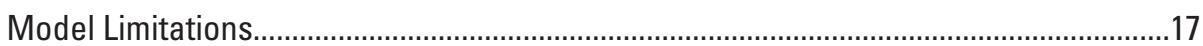

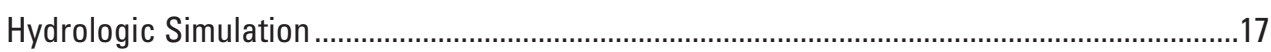

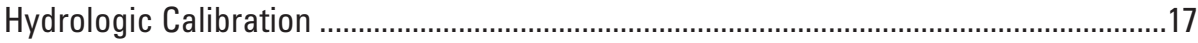

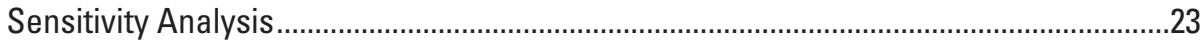

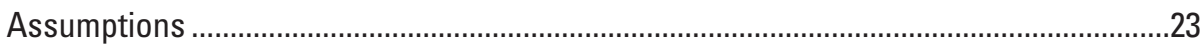

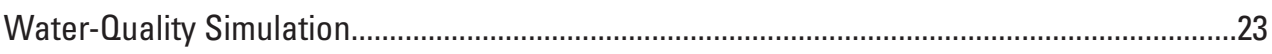

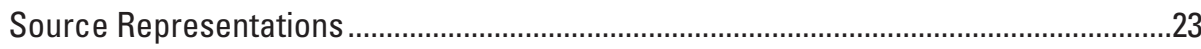

Wastewater-Treatment Plants................................................................................24

City of Springfield Combined Sewer Overflows (CSOs) .......................................24

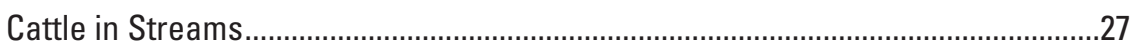

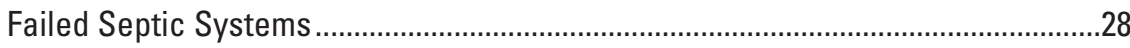

Commercial-Fertilizer and Manure Applications …………….................................28

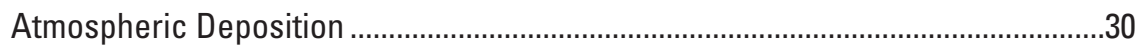

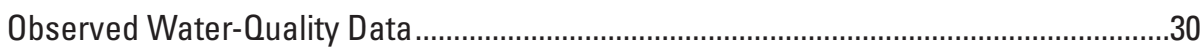

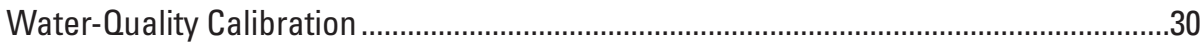

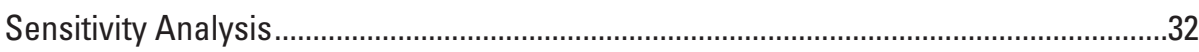

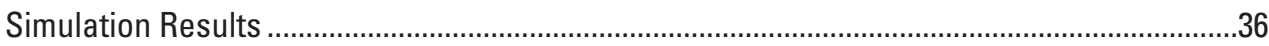

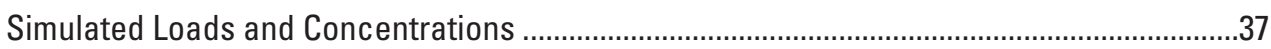

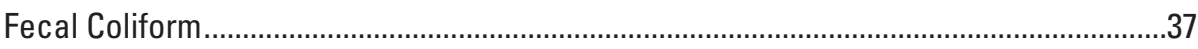

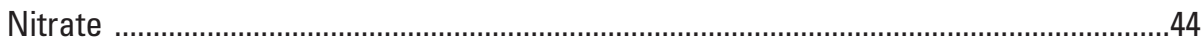

Result of Load-Reduction Simulations …….......................................................................

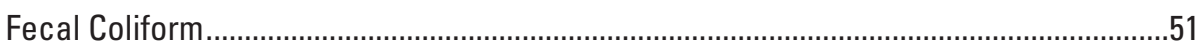

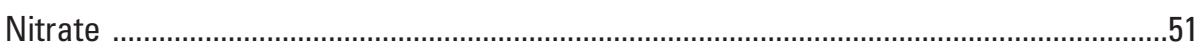

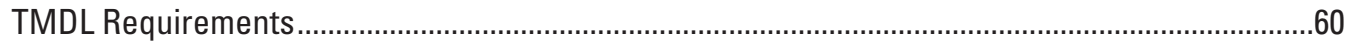


Seasonal and Streamflow Variability ...................................................................................6

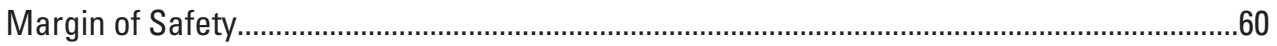

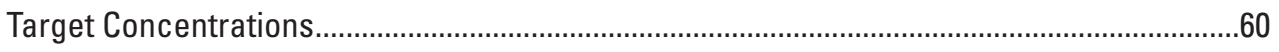

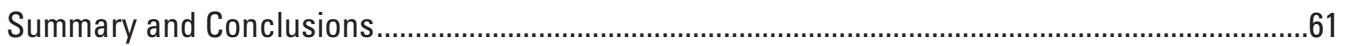

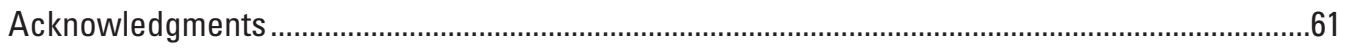

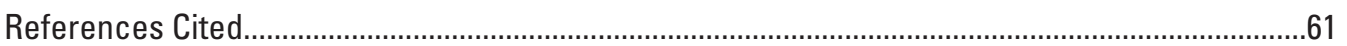

Appendix 1. Percentage of each 14 digit unit with a given land-cover classification...................68

Appendix 2. Values of selected parameters used in calibrated model to simulate

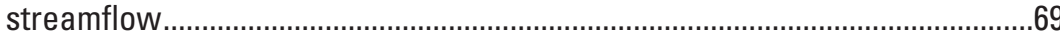

Appendix 3. Parameter values used in calibrated model to simulate fecal coliform concentrations.............................................................................................

Appendix 4. Parameter values used in calibrated model to simulate nitrate concentrations.

\section{Figures}

1-7. Maps showing -

1. Mad River Basin, Ohio ……........................................................................................

2. Generalized surficial geology in the Mad River Basin ...................................................6

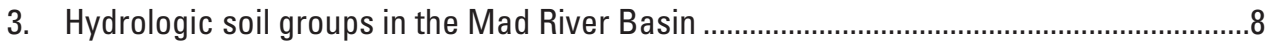

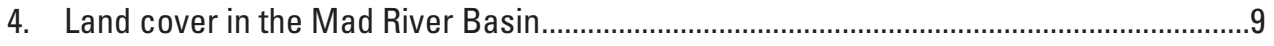

5. Location of streamflow gages and precipitation stations used for construction of the hydrologic model of Mad River Basin.......................................14

6. Location of 14-digit hydrologic units in Mad River Basin ..

7. Location of 52 modeled subbasins and 9 meteorologic zones in the Mad River Basin

8a. Graph showing relation of simulated daily mean streamflow to observed daily streamflow for Mad River at West Liberty (03266560) and Mad River at St. Paris Pike (03267900), January 1, 1999, through December 31, 2003

8b. Graph showing relation of simulated daily mean streamflow to observed daily streamflow for Mad River at Springfield (03269500) and Mad River at Huffman Dam (03270000), January 1, 1999, through December 31, 2003

9. Graph showing flow-duration curves of simulated and observed streamflows for Mad River at West Liberty (03266560), Mad River at St. Paris Pike (03267900), Mad River near Springfield (03269500), and Mad River at Huffman Dam (03270000), 1999-2003

10. Map showing locations of water-quality stations used for calibration of the water-quality model and locations of wastewater-treatment plants and combined-sewer overflows in the Mad River Basin

11-12. Graphs Showing -

11a. Simulated daily mean streamflow, simulated daily mean concentrations of nitrate and fecal coliform, and observed instantaneous concentrations, Mad River at St. Paris Pike, January 1, 1999, through June 30, 2001 
11b. Simulated daily mean streamflow, simulated daily mean concentrations of nitrate and fecal coliform, and observed instantaneous concentrations, Mad River at St. Paris Pike, July 1, 2001, through December 31, 2003.

12. Simulated daily mean streamflow, simulated daily mean concentrations of nitrate and fecal coliform, and observed instantaneous concentrations, Mad River at Huffman Dam July 15, 2003 through Septmber 30, 2003

13-14. Maps showing -

13. Simulated maximum 30-day geometric mean concentrations of fecal coliform from calibrated model and source-reduction model, Mad River Basin, 1999-2003

14. Simulated mean concentrations of nitrate from calibrated model and source-reduction model, Mad River Basin, 1999-2003

\section{Tables}

1. Selected previous studies including all or part of the Mad River Basin ............................4

2. Hydrologic soil groups in the Mad River Basin ...........................................................

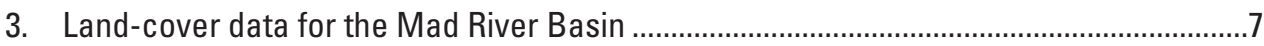

4. Annual and total precipitation at meteorological stations near the Mad River Basin, 1999-2003 ...............................................................................13

5. Calibration criteria, simulation error, and validation results at four streamflow gages in the Mad River Basin .................................................................

6. Comparison of simulated and estimated median annual base flow, 1999-2002 ..............22

7. Sensitivity of modeled runoff characteristics at gaging station 03270000 to variations in selected hydrologic model parameters for the period 1999-2003.

8. Point-source dischargers included in the Hydrological Simulation Program-Fortran model of the Mad River Basin .

9. Equations relating precipitation and next-day daily mean streamflow to combined-sewer-overflow (CSO) discharge volume for each subbasin with a CSO

10. Fraction of commercial fertilizer applied by month, by crop type ...................................29

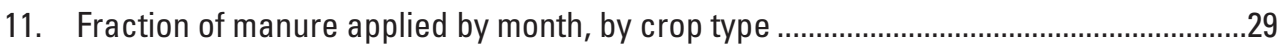

12. Wet and dry deposition of nitrate, by season, at three national atmospheric deposition program/national trends network stations in Ohio, 1999-2003 ...............29

13. Water-quality data from surface-water sites used to calibrate the model of the Mad River Basin

14. Comparison of observed and simulated nitrate and fecal coliform concentrations at sites in the Mad River Basin, 1999-2003.

15. Sensitivity analyses of modeled water-quality characteristics to variations in selected water-quality model parameters for the mouth of the Mad River during calibration period 1999-2003..

16. Mean fecal coliform loads per recreation season from nonpoint sources simulated from calibrated model and sourcereduction model, 1999-2003.

17. Mean fecal coliform load per recreation season from selected sources and totals from nonpoint sources simulated from calibrated model and source-reduction model, 1999-2003.

18. Fecal coliform and nitrate loads at outlet of each 14-digit hydrologic unit and loads contributed by each hydrologic unit, 1999-2003. 
19. Fecal coliform concentrations simulated from calibrated model, 1999-2003

20. Mean annual nitrate loads from nonpoint sources simulated from calibrated model and source-reduction model, 1999-2003.

21. Mean annual nitrate load from selected sources and totals from nonpoint sources simulated from calibrated model and source-reduction model, 1999-2003

22. Nitrate concentrations simulated from calibrated model, 1999-2003

23. Nitrate and fecal coliform loads at outlet of each 14-digit hydrologic unit simulated from source-reduction model, 1999-2003

24. Fecal coliform and nitrate concentrations by 14-digit hydrologic unit simulated from source-reduction model, 1999-2003

\section{Conversion Factors, Datums, and Abbreviations}

\begin{tabular}{|c|c|c|}
\hline Multiply & By & To obtain \\
\hline \multicolumn{3}{|c|}{ Length } \\
\hline inch (in.) & 2.54 & centimeter $(\mathrm{cm})$ \\
\hline foot $(\mathrm{ft})$ & 0.3048 & meter $(\mathrm{m})$ \\
\hline meter $(\mathrm{m})$ & 3.281 & foot $(\mathrm{ft})$ \\
\hline mile (mi) & 1.609 & kilometer $(\mathrm{km})$ \\
\hline \multicolumn{3}{|c|}{ Area } \\
\hline acre & 0.004047 & square kilometer $\left(\mathrm{km}^{2}\right)$ \\
\hline square mile $\left(\mathrm{mi}^{2}\right)$ & 2.590 & square kilometer $\left(\mathrm{km}^{2}\right)$ \\
\hline \multicolumn{3}{|c|}{ Volume } \\
\hline milliliter $(\mathrm{mL})$ & 0.06102 & cubic inch $\left(\mathrm{in}^{3}\right)$ \\
\hline liter (L) & 0.03531 & cubic foot $\left(\mathrm{ft}^{3}\right)$ \\
\hline gallon (gal) & 3.785 & liter (L) \\
\hline$\underline{\text { million gallons (Mgal) }}$ & 3,785 & cubic meter $\left(\mathrm{m}^{3}\right)$ \\
\hline \multicolumn{3}{|c|}{ Flow rate } \\
\hline gallon per day (gal/d) & 0.003785 & cubic meter per day $\left(\mathrm{m}^{3} / \mathrm{d}\right)$ \\
\hline million gallons per day (Mgal/d) & 0.04381 & cubic meter per second $\left(\mathrm{m}^{3} / \mathrm{s}\right)$ \\
\hline
\end{tabular}

Temperature in degrees Fahrenheit $\left({ }^{\circ} \mathrm{F}\right)$ may be converted to degrees Celsius $\left({ }^{\circ} \mathrm{C}\right)$ as follows:

${ }^{\circ} \mathrm{C}=\left({ }^{\circ} \mathrm{F}-32\right) / 1.8$

Vertical coordinate information is referenced to the North American Vertical Datum of 1988 (NAVD 88).

Horizontal coordinate information is referenced to the North American Datum of 1983 (NAD 83).

Altitude, as used in this report, refers to distance above the vertical datum.

Concentrations of chemical constituents in water are given in milligrams per liter ( $\mathrm{mg} / \mathrm{L})$.

Concentrations of bacteria are given in colonies per 100 milliliters (col/100 mL). 


\title{
Simulation of Streamflow and Water Quality to Determine Fecal Coliform and Nitrate Concentrations and Loads in the Mad River Basin, Ohio
}

\author{
By David C. Reutter, Barry M. Puskas, and Martha L. Jagucki
}

\section{Abstract}

The Hydrological Simulation Program-Fortran (HSPF) was used to simulate the concentrations and loads of fecal coliform and nitrate for streams in the Mad River Basin in west-central Ohio during the period 1999 through 2003. The Mad River Basin was divided into subbasins that were defined either by the 14-digit Hydrologic Unit (HU) boundaries or by streamflow-gaging-station locations used in the model. Model calibration and simulation processes required the formation of nine meteorologic zones to input meteorologic time-series data and water-quality data.

Sources of fecal coliform and nitrate from wastewatertreatment discharges and combined sewer overflow discharges (CSOs) within the City of Springfield were point sources simulated in the model. Failing septic systems and cattle with direct access to streams were nonpoint sources included in the study but treated in the model as point sources. Other nonpoint sources were addressed by adjusting interflow and groundwater concentrations in the subsurface and maximum storage capacities and accumulation rates of the simulated constituents on the land surface for each meteorologic zone. Simulation results from the calibrated model show that several HUs exceeded the water-quality standard of 1,000 colony-forming units per $100 \mathrm{~mL}$ for fecal coliform based on the maximum 30-day geometric mean. Most HUs with high fecal coliform counts were within or downstream from the City of Springfield. No water-quality standard has been set for instream nitrate concentrations; however, the Ohio Environmental Protection Agency (Ohio EPA) considered a concentration of $5 \mathrm{mg} / \mathrm{L}$ or greater to be of concern. Simulation results indicate that several HUs in the agricultural areas of the basin exceeded this level.

The calibrated model was modified to create scenarios that simulated loads of fecal coliform and nitrate that were either reduced or eliminated from selected sources. The revised models included the elimination of failing septic systems, elimination of direct access of cattle to streams, decrease in fecal coliform loads from the CSOs and selected wastewater-treatment facilities, and decrease in nitrate loads from land surfaces. The fecal coliform source-reduction model decreased the fecal coliform concentrations below a target concentration of 1,000 colonies per 100 milliliters for all HU outlets and decreased the load at the mouth of the Mad River by 73 percent. The nitrate source-reduction model decreased some HU mean concentrations to 5 milligrams per liter or less and decreased the load at the mouth of the Mad River by 52 percent. Other reduction scenarios may be run by Ohio EPA with the intent of identifying a management strategy that will attain a target concentration for the Mad River Basin.

\section{Introduction}

Stream waters of the Mad River Basin (fig. 1) are used for recreation, agricultural and industrial water supply, and support of aquatic life. Long-term availability of water for some of these uses is threatened, however, because several segments of the Mad River Basin are listed under Section 303(d) of the Federal Clean Water Act as not being in compliance with Ohio Water Quality Standards (WQS). An extensive evaluation of the Mad River Basin by Ohio Environmental Protection Agency (Ohio EPA) (2005a) found that, throughout the basin, ambient-water-quality standards for fecal coliform bacteria are exceeded (geometric mean of five or more samples within a 30-day period exceeds $1,000 \mathrm{col} / 100 \mathrm{~mL}$ and (or) more than 10 percent of samples within the 30-day period exceed 2,000 col/100 mL). Other causes of impairment to specific stream segments include nutrient and organic enrichment resulting from agricultural activities, urban runoff, or wastewater-treatment plants (Ohio Environmental Protection Agency, 1998, 2005a). Habitat alteration due to channelization also has degraded several stream segments in the watershed (Ohio Environmental Protection Agency, 1998, 2004, and 2005a).

To bring all streams in the basin into compliance with Ohio WQS will require quantification of contamination loads contributed by various sources, information regarding the effects of different land covers and other land-surface characteristics on water quality, and documentation of the response 
of contaminant loads to precipitation events and various flow conditions. Such information will serve as a basis for waterresource-management decisions in the basin.

To quantify loads and concentrations of nitrate and fecal coliform in the Mad River Basin and to estimate these concentrations over a range of hydrologic conditions, the U.S. Geological Survey (USGS), in cooperation with the Ohio EPA, used a watershed model called Hydrological Simulation Program-Fortran (HSPF). HSPF simulates transport and storage of water and associated water-quality constituents, as well as instream chemical reactions (Bicknell and others, 1997). HSPF is included as part of the U.S. Environmental Protection Agency (USEPA) Better Assessment Science Integrating point and Nonpoint Sources (BASINS) program. HSPF is also one of several principal models currently recommended by the USEPA Office of Water for determining the Total Maximum Daily Load (TMDL) of a pollutant that a stream can receive from point, nonpoint, and background sources and still meet state water-quality standards with an adequate margin of safety. The process of developing a TMDL for a pollutant helps the Ohio EPA identify the amount by which both point and nonpoint sources in impaired stream segments must be reduced. Subsequently, scientifically based restoration solutions can be implemented with the ultimate goal of reaching full attainment of biological and chemical WQS within each stream segment and, thereafter, removal of the waterbody or waterbodies from the 303(d) "impaired" list.

\section{Purpose and Scope}

This report describes the development and calibration of an HSPF model to simulate streamflow and the transport of fecal coliform bacteria and nitrates. The model was developed under the USEPA 319 grant program in support of a TMDL that will be prepared by the Ohio EPA. The model simulation period is January 1999 through December 2003, based on availability of both streamflow and water-quality data. Current water-quality conditions in the Mad River Basin are described. Locations of point sources and their fecal coliform and nitrate loads are presented, as well as estimates of fecal coliform and nitrate loads from nonpoint sources, including groundwater discharge to streams. The calibrated model is used to calculate the loads of fecal coliform bacteria and nitrate in the Mad River Basin and to evaluate where these loads exceed the targets established by Ohio EPA. Load-reduction scenarios prescribed by Ohio EPA are simulated, and the resulting loads are presented. Loads are converted to mean annual nitrate and 30-day geometric mean fecal coliform concentrations to assess whether the source-reduction scenarios will achieve Ohio EPA target concentrations.

Several topics are beyond the scope of this report, and will be addressed instead in the Ohio EPA TMDL report for the Mad River Basin. For example, stream impairment caused by habitat alteration is not addressed in this report. Designation of specific load-reduction scenarios as the TMDLs for fecal coliform and nitrate in the Mad River Basin will be addressed by Ohio EPA. Similarly, an implementation plan for achieving TMDL targets is excluded from this report but will be addressed by Ohio EPA in their TMDL report to USEPA.

\section{Previous Studies}

The information base for the Mad River Basin is relatively rich. Several studies on a variety of water-resources topics have focused on all or part of the Mad River Basin (table 1). Because it has long been documented that the Mad River has an unusually large base-flow component (Leverett, 1902), the interaction of ground water and surface water has been of special interest in the area.

One reason for the abundance of information in the area is the presence of the Miami Conservancy District (MCD). The MCD was established in 1915 to provide flood protection for citizens in the Great Miami River Basin (which includes the Mad River Basin) (Miami Conservancy District, 2005c). With this goal in mind, the USGS and MCD currently operate streamflow-gaging stations ("streamflow gages" hereafter) at four locations on the Mad River. In addition, a crest-stage gage (which is used to determine peak streamflow) is operated on the Mad River near Urbana. Since its founding, MCD has assumed the additional responsibilities of preserving surfaceand ground-water resources and enhancing river corridors. In support of these expanded responsibilities, a surface-waterquality monitoring station was operated for 3 years at one of the four active streamflow gages (the Mad River near Eagle City, in Clark County), ground-water quality and quantity have been regularly monitored since 1997 , and precipitation amounts have been recorded at precipitation gages across the basin (Miami Conservancy District, 2000, 2002, 2003, 2004, 2005b).

Another source of information in the Mad River Basin is the National Water-Quality Assessment (NAWQA) Program. This USGS program was established to describe current waterquality conditions in major river basins and aquifer systems across the Nation, assess how water quality is changing over time, and investigate factors that affect water-quality conditions. Intensive water-quality analysis of the Mad River at St. Paris Pike was done from October 1998 through 2004 as part of the NAWQA program (Shindel and others, 2000, 2001, 2002, 2003, 2004; and 2005, p. 134-138).

Water quality in the Mad River Basin has also been studied by Ohio EPA, Ohio Department of Natural Resources, and other agencies and researchers. Results of these studies are detailed in the "Water-Quality Characterization" section of this report. 


\section{EXPLANATION}

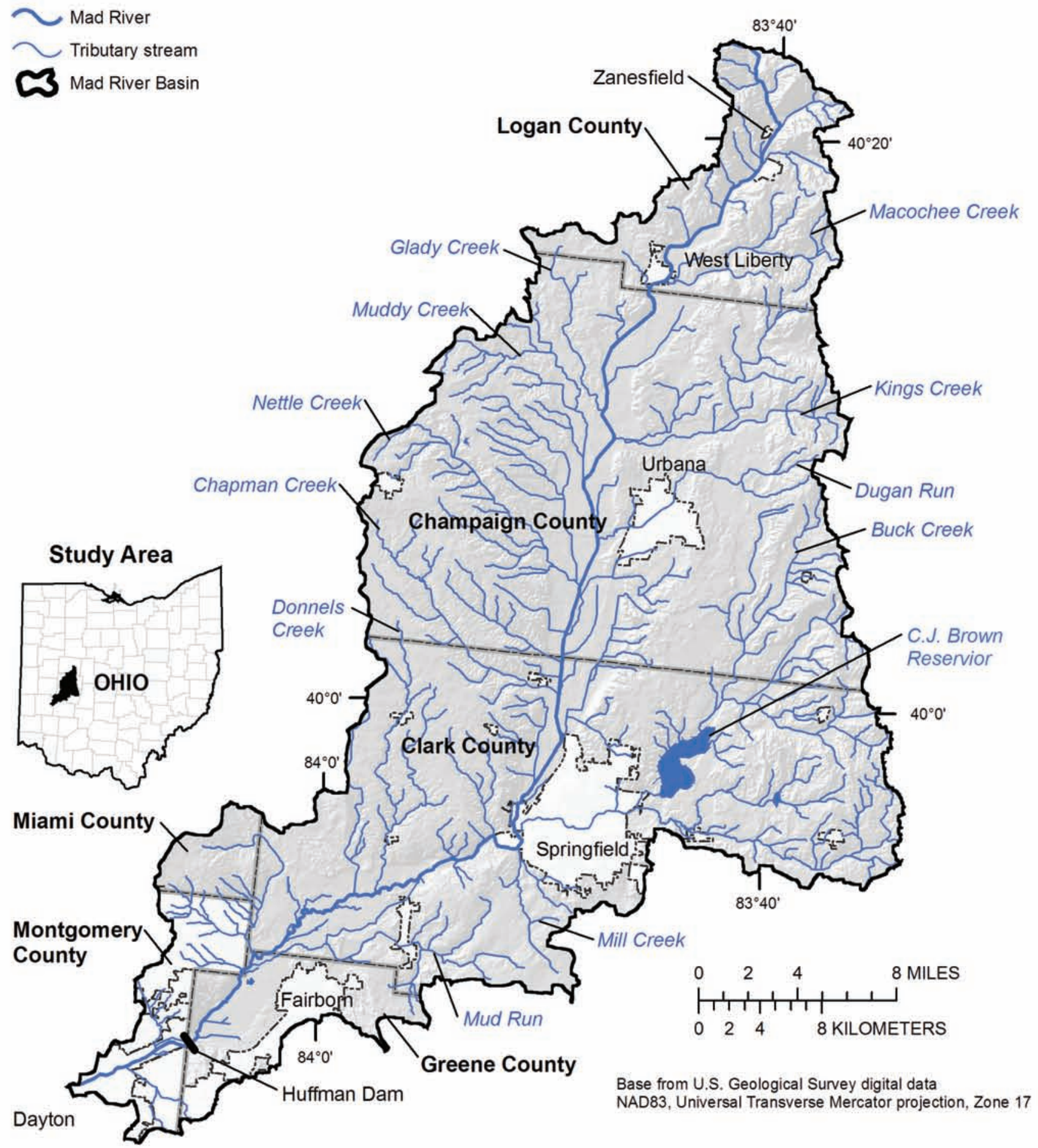

Figure 1. Mad River Basin, Ohio. (Only major streams are labeled; small streams and watersheds are identified in fig. 7.) 
Table 1. Selected previous studies including all or part of the Mad River Basin.

[Full citations for each reference are included in the "References Cited" section of this report]

\begin{tabular}{|c|c|}
\hline Topic & Reference \\
\hline $\begin{array}{l}\text { Water resources of all or part of Mad } \\
\text { River Basin }\end{array}$ & $\begin{array}{l}\text { Leverett (1897, p. 457); Fuller and Clapp (1912), Harker and Bernha- } \\
\text { gen (1943), Norris and others (1948, 1952, 1956), Feulner (1960), and } \\
\text { Schmidt }(1982,1985,1991)\end{array}$ \\
\hline Geology & Orton (1874), Hill (1878), Forsyth (1956), and Quinn and Goldthwait (1979) \\
\hline Delineation of the Teays River Valley & Norris and Spicer (1958) \\
\hline $\begin{array}{l}\text { Ancestral drainage paths of the Mad } \\
\text { River near Dayton }\end{array}$ & Richard and others (1979) \\
\hline Geohydrology & Speiker and Durrell (1961) and Smindak (1992) \\
\hline $\begin{array}{l}\text { Interaction of ground water and surface } \\
\text { water }\end{array}$ & $\begin{array}{l}\text { Cross and Feulner (1964), Norris and Eagon (1971), Sheets and Yost (1994), } \\
\text { Koltun (1995), Yost (1995), Jones and others (1996), and Dumouchelle } \\
\text { (2001) }\end{array}$ \\
\hline $\begin{array}{l}\text { Transport of hypothetical contami- } \\
\text { nants in the hydraulically connected } \\
\text { stream-aquifer system }\end{array}$ & Hussein and Schwartz (2003) \\
\hline Water (resource/quality) monitoring & $\begin{array}{l}\text { Miami Conservancy District }(2002,2003,2004,2005 b) \text {, Debrewer and oth- } \\
\text { ers (2000), Jones and others (1996), Rankin and others (1997), Reutter } \\
\text { (2003), Rowe and others (2004), U.S. Geological Survey }(2000,2005 \mathrm{c}) \text {, } \\
\text { and Ohio Environmental Protection Agency }(1986,1994,2005 \mathrm{a})\end{array}$ \\
\hline Temporal water-quality trends & Pennino (1984) \\
\hline Effects of urban stormwater runoff & Burton and others (2001) \\
\hline $\begin{array}{l}\text { Assessments of biota, fish tissue, and } \\
\text { stream sediment }\end{array}$ & $\begin{array}{l}\text { Janosy (2003), and Ohio Environmental Protection Agency }(1986,1994, \\
\text { 2005a) }\end{array}$ \\
\hline $\begin{array}{l}\text { Effects of Wright-Patterson Air Force } \\
\text { Base on the biology, sediment, and } \\
\text { water quality of the Mad River }\end{array}$ & Ohio Environmental Protection Agency (1994) \\
\hline
\end{tabular}

\section{Basin Description}

The Mad River is in west-central Ohio and drains approximately $657 \mathrm{mi}^{2}$. From its headwaters in Logan County, the Mad River flows south and west through Champaign, Clark, and Greene Counties to its confluence with the Great Miami River in Montgomery County (fig.1). Tributaries to the Mad River with drainage areas greater than $20 \mathrm{mi}^{2}$ are Buck Creek, Chapman Creek, Donnels Creek, Dugan Run, Kings Creek, Muddy Creek, and Nettle Creek. The urban areas of Dayton, Fairborn, Springfield, Urbana, and West Liberty are partly or wholly contained within the Mad River Basin. C.J. Brown Reservoir, constructed on Buck Creek in Clark County in 1972 (Koltun, 1995), is a deep-water lake that covers 2,120 acres and is the sole large reservoir in the study area (U.S. Army Corps of Engineers, 2005; Dayton Audubon Society, 2005). For temporary storage of floodwaters, Huffman Dam was built across the Mad River near Fairborn in northwestern Greene County; however, Huffman Dam has no permanent pool. Under normal flow conditions, waters of the Mad River pass through conduits at the base of the dam; only in times of excess flow do waters back up behind the dam (Miami Conservancy District, 2005a).

\section{Physical and Hydrologic Setting}

Topography at the northern end of the Mad River Basin (fig. 1) consists of gently rolling hills dissected by steepwalled river valleys. The highest point in the study area (and in Ohio) is in Logan County, with an altitude of 1,539 ft near the headwaters of the basin. Further south in Champaign and Clark Counties, the land is relatively flat and consists of some of the richest farmland in Ohio (Mad River Steering Committee, 2003b); however, very steep valley walls can be found 
along the major drainageways. The lowest altitude $(712 \mathrm{ft})$ is near the mouth of the Mad River in Montgomery County.

The natural flow of the Mad River was altered at the beginning of the 20th century with the advent of flood control. Levees were constructed, and reaches of the Mad River and its tributaries were channelized. Besides altering streamflow, flood-control measures allowed for agricultural development of many additional acres, bringing about degradation of surface- and ground-water quality and subsequent alteration of the native fish population (Mad River Steering Committee, 2003b). Dredging in the Mad River in the period 1955-80 created further change in fish communities. Straightening of channels and the elimination of pools and riffles altered stream habitats (Harrington, 1999). Deepening of the channels from Buck Creek to the headwaters has caused greater influx of ground water to the streams, resulting in cooler stream-water temperatures (Ohio Environmental Protection Agency, 2005a).

\section{Climate}

Average annual air temperatures in the Mad River Basin range from about 51 to $53^{\circ} \mathrm{F}$ (Harstine, 1991). Average annual precipitation ranges from 36.7 to 39.6 in. Long-term precipitation averages are based on the entire period of record (in many cases greater than 80 years) at nine stations, as recorded by MCD observers (Miami Conservancy District, 2000). March through August tend to be the wettest months, with peak precipitation occurring in May and June, whereas February is the driest month (Miami Conservancy District, 2000). Debrewer and others (2000), when examining precipitation data in the Great and Little Miami Watersheds over a 30-year period (1961-90), found that precipitation events in spring and summer have usually been associated with thunderstorms that tend to be short and intense. In contrast, precipitation events in the fall and winter have usually been longer and of mild intensity.

\section{Hydrogeology}

The Mad River occupies an area that was affected by Pleistocene glaciation. Most of its course lies between what were historically the Miami and Scioto lobes of the Wisconsinan glacier (Cross and Hedges, 1959). As the lobes advanced or as stagnant ice melted, a blanket of till (an unsorted mixture of clay, silt, sand, and gravel) was deposited over the area (fig 2). Later, large volumes of glacial meltwater filled erosional valleys carved in the till and bedrock with coarse-grained, stratified sediments called outwash. Outwash terraces and extensive outwash deposits up to 3 mi wide characterize much of the Mad River Basin (Cross and Feulner, 1964). The finegrained stratified sediments between Dugan Run and Buck Creek were deposited in a lacustrine setting, perhaps in a basin or valley dammed by glacial ice (Debrewer and others, 2000).

Outwash deposits are highly permeable and readily transmit ground water. Ground water is the primary source of drinking water for residents in the upper part of the basin; the aquifer system has been designated as a Sole-Source Aquifer for the region and named the "Mad River Buried Valley Aquifer" (Mad River Steering Committee, 2003b). Ground water also discharges to the Mad River in amounts that are uncommonly large compared to other rivers in Ohio (Leverett, 1902; Koltun, 1995). Koltun (1995) reports that the median percentage of annual total streamflow contributed by base flow from ground water ranges from 61.8 (at Zanesfield) to 76.1 percent (near Urbana). Because the permeable glacial deposits are not uniformly distributed, contribution of ground water to the tributaries within the Mad River Basin is variable. Jones and others (1996) measured instantaneous discharge of the Mad River and various tributaries during low-flow conditions. Gains in flow between upstream and downstream reaches were computed for the tributaries and were attributed to ground-water discharge to the stream. The highest base flows per square mile of surface drainage area were found in the subbasins of Kings Creek, Macochee Ditch, and Mad River north of West Liberty. Base flows are lowest in Glady Creek and Muddy Creek. Jones and others (1996) also note large base-flow gains on the Mad River between West Liberty and Urbana and attribute the gains to high rates of ground-water recharge along the low terraces bordering the river in this area. In contrast, poorly permeable strata line reaches of the Mad River near Springfield and also at Huffman Dam, near the boundary between Greene and Montgomery Counties (Cross and Feulner, 1964). In these locations, valley fill is constricted by bedrock gorges. The gorge through which the stream passes at Springfield is approximately $1 / 8 \mathrm{mi}$ wide (Cross and Feulner, 1964) and is cut into Silurian limestone, whereas the gorge at Huffman Dam cuts through Ordovician limestone and shale.

Because of the high amount of ground-water contribution to streamflow in areas where permeable glacial deposits are present, the upper part of the Mad River and selected tributaries have been designated as cold-water habitat (Ohio Environmental Protection Agency, 2005a). Cold-water habitat describes those waters capable of supporting native populations of cold-water fish, plants, and other organisms on an annual basis or waters that support trout stocking and management (Ohio Environmental Protection Agency, 2002).

\section{Soils}

Soils in the Mad River Basin have been classified into hydrologic groups by the National Resources Conservation Service (NRCS) (U.S. Department of Agriculture, 1991a). When storm and cover conditions are similar, soils within a single hydrologic group have similar runoff potential. Runoff potential refers to the likelihood that precipitation and snowmelt will flow over the land surface rather than infiltrate into the ground, and it is based on surface slope and saturated hydraulic conductivity of the upper 1 meter of soil or bedrock material. Runoff potential is estimated for bare, thoroughly wetted, and unfrozen soils. Runoff potential is influenced by "depth to a seasonally high water table, saturated hydraulic conductivity after prolonged wetting, and depth to a layer 


\section{EXPLANATION}

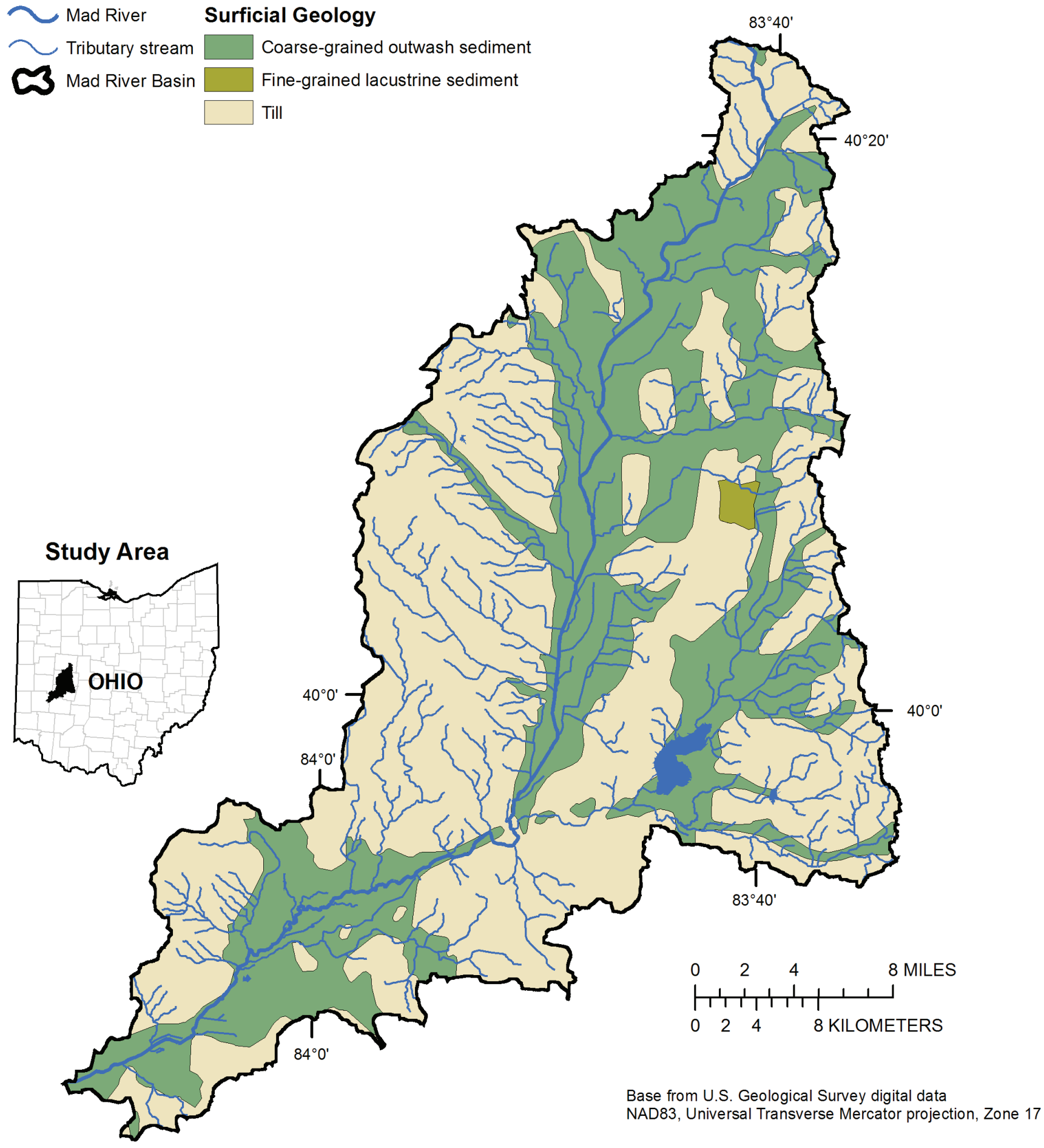

Figure 2. Generalized surficial geology in the Mad River Basin. (Data from Soller, 1993, 1998 as reported by Debrewer and others, 2000.) 
with a very slow water transmission rate" (U.S. Department of Agriculture, 2005). Soils with a low runoff potential have a high infiltration rate; those with a high runoff potential have a low infiltraton rate. Distribution of soils by hydrologic group (table 2) are shown in figure 3 and were obtained from the State Soil Geographic (STATSGO) database created by the NRCS (U.S. Department of Agriculture, 1991a). This database, designed for regional and river-basin-level planning and monitoring, was created by generalizing more detailed soil-survey maps. The STATSGO database was the most recent dataset available for all counties in the Mad River Basin when the study began. Of the hydrologic soil groups found in the Mad River Basin, group B soils generally have the lowest runoff potential. These soils are found along much of the main stem of the Mad River and in the vicinity of some tributaries, including Buck Creek and Kings Creek, and generally coincide with the presence of outwash in the basin (fig. 2). Group C soils cover much of the basin and are generally associated with till deposits. Group D soils (which cover a very small area at the north end of the basin, as well as areas in the Mill Creek and Mud Run Subbasins) have the greatest runoff potential.

Table 2. Hydrologic soil groups in the Mad River Basin.

\begin{tabular}{|c|c|}
\hline $\begin{array}{l}\text { Hydrologic } \\
\text { group }\end{array}$ & Definition \\
\hline B & $\begin{array}{l}\text { Silt loam or loam. Moderate infiltration rate when thoroughly wetted. Moderately deep to deep, mod- } \\
\text { erately well drained to well drained soils that have moderately fine to moderately coarse texture. } \\
\text { Moderate rate of water transmission. }\end{array}$ \\
\hline $\mathrm{C}$ & $\begin{array}{l}\text { Sandy clay loam. Slow infiltration rates when thoroughly wetted. Soils chiefly have a layer that } \\
\text { impedes downward movement of water or have moderately fine to fine texture. Slow rate of water } \\
\text { transmission. }\end{array}$ \\
\hline D & $\begin{array}{l}\text { Clay loam, silty clay loam, sandy clay, silty clay, or clay. Very slow infiltration rates when thoroughly } \\
\text { wetted. Soils chiefly have a high swelling potential, have a permanent high water table, have a clay- } \\
\text { pan or clay layer at or near the surface, or are shallow soils over nearly impervious material. Very } \\
\text { slow rate of water transmission. }\end{array}$ \\
\hline
\end{tabular}

Table 3. Land-cover data for the Mad River Basin.

[Land-cover data obtained from U.S. Geological Survey, 1992. Some categories were reclassified for the model, as indicated below. NLCD, National Land Cover Dataset 1992; HSFP, Hydrological Simulation Program-Fortran]

\begin{tabular}{|c|c|c|c|c|}
\hline NLCD classification & Percent & HSPF model aggregate classification & Percent & Percent impervious \\
\hline Open water & 0.91 & Water & 0.91 & 0 \\
\hline Low-intensity residential & 5.20 & Low-intensity residential & 5.20 & 5 \\
\hline High-intensity residential & 1.29 & High-intensity residential & 1.29 & 15 \\
\hline Commercial/industrial/transportation & 2.67 & Commercial/industrial/transportation & 2.67 & 60 \\
\hline Quarries/strip mines/gravel pits & 0.00 & & & \\
\hline Transitional & 0.04 & Urban or built-up land & 2.24 & 10 \\
\hline Urban/recreational grasses & 2.20 & & & \\
\hline Deciduous forest & 12.42 & & & \\
\hline Evergreen forest & 0.15 & & & \\
\hline Mixed forest & 0.02 & Forest land & 12.93 & 0 \\
\hline Woody wetlands & 0.24 & & & \\
\hline Emergent herbaceous wetlands & 0.10 & & & \\
\hline Pasture/hay & 17.74 & Pasture & 17.74 & 0 \\
\hline Row crops & 57.01 & Agricultural land & 57.01 & 0 \\
\hline
\end{tabular}




\section{EXPLANATION}

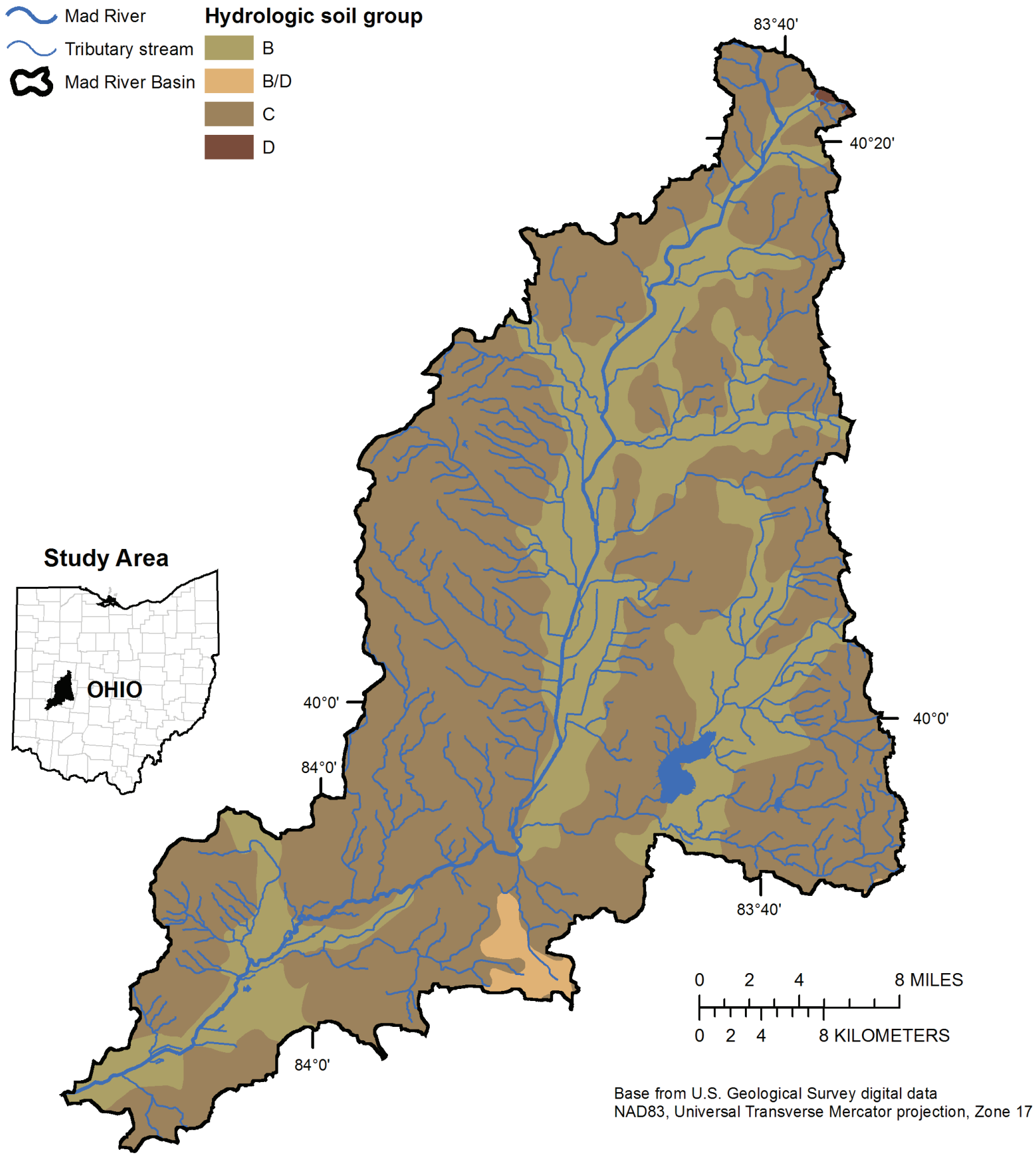

Figure 3. Hydrologic soil groups in the Mad River Basin. (Data from U.S. Department of Agriculture, 1991a.) 


\section{EXPLANATION}

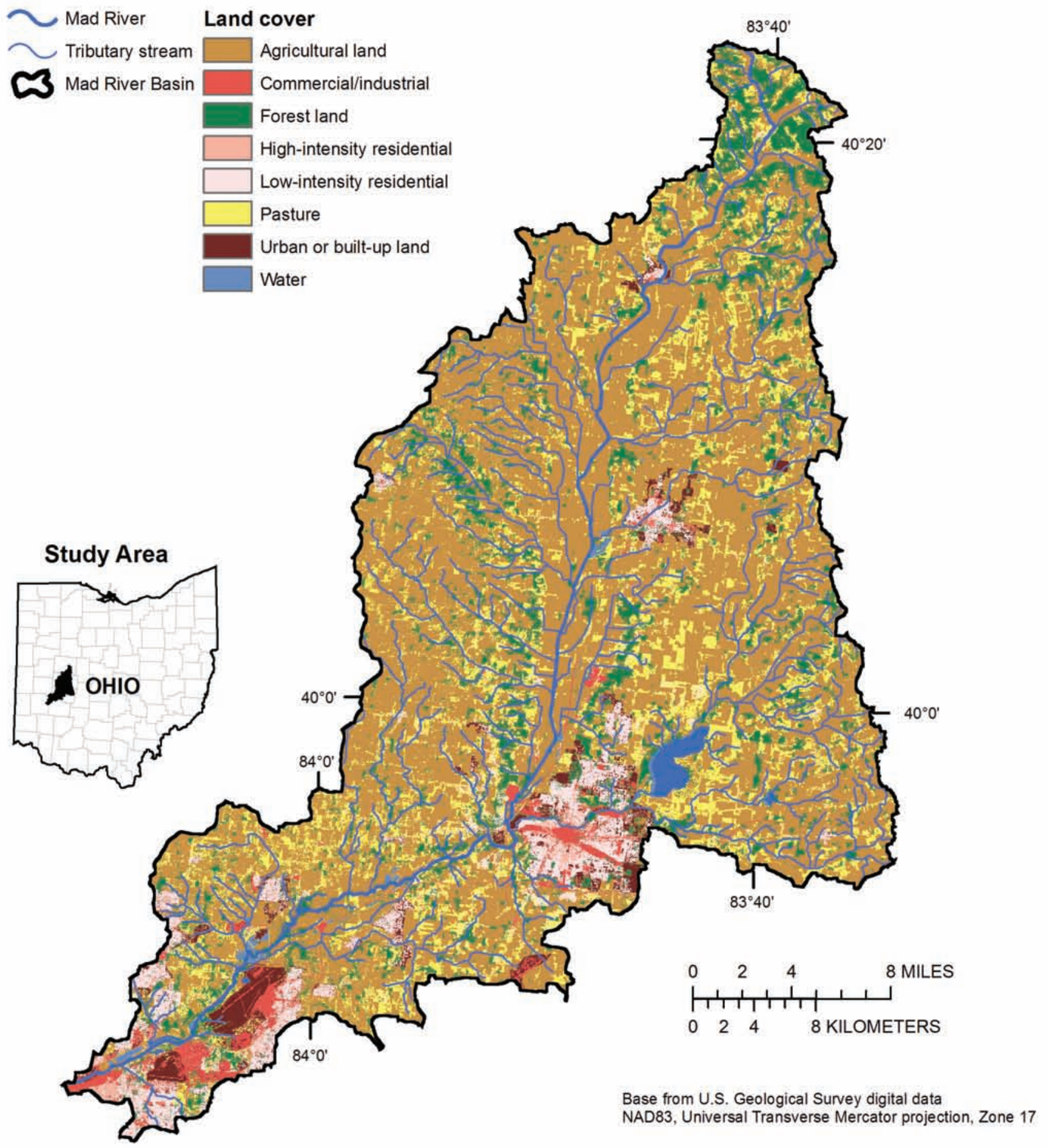

Figure 4. Land cover in the Mad River Basin. (Data from U.S. Geological Survey, 1992.) 


\section{Land cover}

Land-cover data in the Mad River Basin were derived from the National Land Cover Dataset (NLCD) (U.S. Geological Survey, 1992). This was the most recent dataset available when the study began.

Land cover in the Mad River Basin, as described in table 3 (p. 7) and figure 4 (p. 9), is primarily agricultural, with approximately 57 percent of the land planted in row crops and almost 18 percent used for pasture. Approximately 13 percent of the basin is forested. Land-cover percentages calculated for each subbasin (Appendix 1) indicate that the percentage of forest is highest in the headwaters region of the Mad River, from the Machochee Creek Subbasin north.

Residential properties cover approximately 6.5 percent of the Mad River Basin, but most of this is land classified as low-intensity residential, which commonly includes singlefamily housing units in areas with a mixture of constructed materials and vegetation. Less than 2 percent of the land cover is classified as high-intensity residential, where people live in high numbers and vegetation accounts for less than 20 percent of the land cover (U.S. Geological Survey, 2003). Most of the high-intensity residential land cover is in the Dayton and Springfield areas. Springfield is in the Buck Creek Subbasin.

\section{Water Quality}

The Mad River and its tributaries are affected by point and nonpoint sources of pollution. Point sources are those that discharge from a discrete location, such as a pipe or drainage ditch. Nonpoint-source pollution does not have a single point of origin but rather comes from diffuse sources over a relatively large area. Contaminants from nonpoint sources reach a stream either in surface runoff, interflow, or seepage to ground water from precipitation on a land cover; through air pollution; or from malfunctioning septic systems. Typical nonpointsource contaminants include fertilizer and pesticides applied to agricultural fields or suburban lawns. Agencies and individuals who have previously investigated water quality in the Mad River Basin agree that nonpoint sources of pollution have significantly affected the basin's water quality (Pennino, 1984; Rankin and others, 1987; Reutter, 2003; Miami Conservancy District, 2004; Rowe and others, 2004). Ohio EPA has been tasked with assessing the effects of both point and nonpoint sources of pollution on the quality of water in the Mad River Basin (as well as other waterbodies in Ohio) and ensuring that the chemical, physical, and biological integrity of the State's waters are restored and maintained (Section 101a of Public Law 92-500).

\section{Designated Uses}

Ohio EPA has done several assessments of streams in the Mad River Basin beginning in 1986 to evaluate whether particular waterbodies are achieving Clean Water Act goals of being fishable and swimmable. First, Ohio EPA must establish designated uses for each stream segment, meaning that the waterbody has the potential to support that use. Use designations are divided into three categories: (1) aquatic life habitat, indicating the types of organisms the waters are capable of supporting, (2) water supply, indicating the type of consumptive use by humans for which the waters are suitable, and (3) recreation, designating the type of body contact for which the waters are suitable. The type of use designation given to a waterbody affects the criteria applied to ensure that the waters are fishable and swimmable, thus affecting the target concentrations assigned later in this report.

The two use designations pertinent to this report are aquatic life use and recreational use. For aquatic life use, Ohio EPA has designated the Mad River main stem (from the headwaters to Buck Creek) and several tributaries as coldwater habitat; downstream from Buck Creek, the aquatic-life use designation of the Mad River main stem is warm-water habitat. For recreational water use, all waters except West Liberty Tributary have been designated as primary contact waters (Ohio Environmental Protection Agency, 2005a).

The most recent evaluation of the Mad River Basin by Ohio EPA was done, in part, to facilitate the TMDL calculation. Ohio EPA (2005a) did a basinwide assessment of fish and macroinvertebrate communities, water chemistry, and sediment chemistry from June to October 2003. General findings were that extensive channelization to facilitate agricultural production from Buck Creek to the headwaters has affected fish communities in the upper part of the basin. Deepening of the channels has caused greater influx of ground water to the streams and, as a result, has made the water temperatures cooler. In some cases (Macochee Ditch, Kings Creek, Dugan Run, Muddy Creek, tributary to Nettle Creek, Buck Creek downstream from C.J. Brown Reservoir, Moore Run, and Kenton Creek), limited sinuosity and lack of instream cover have adversely affected the fish and macroinvertebrate communities.

\section{Fecal Coliform}

Concentration of fecal coliform bacteria is one measure used to assess recreational water quality. However, information on fecal coliform bacteria in the Mad River Basin is limited. Fecal coliform concentrations in the Mad River at St. Paris Pike have been determined by Ohio EPA since 1999. In 2003, the Upper Mad River Steering Committee began monthly sampling for fecal coliform bacteria at 10 sites throughout the basin (Mad River Steering Committee, 2003a; data on file at the The Oho State University Extension, Champaign County). Although no published studies have resulted from these analyses, the raw fecal coliform data from both of these groups were used in this study for model calibration purposes.

Camp Dresser \& McKee (1997) evaluated the effects of combined-sewer overflows (CSOs) on recreational use of streams in the Springfield area. Stream samples were col- 
lected at six sites within the City of Springfield (in the Buck Creek Basin) and from the Mad River downstream from the Springfield wastewater-treatment plant (WWTP) during the months of May through October 1997. Ten samples were collected during dry weather and three during wet weather (the day of a rain event and for three consecutive days thereafter). Dry-weather samples contained from 24 to 2,267 colonies of fecal coliform bacteria per $100 \mathrm{~mL}$ of water and were within water-quality standards (fewer than 10 percent of samples within a 30-day period exceeded 2,000 col/100 mL). Wetweather samples revealed that water-quality standards for fecal coliform were exceeded for one to two days after a rainfall event in response to CSO discharges. A maximum concentration of 238,000 col/100 $\mathrm{mL}$ of water was observed during the wet-weather sampling on the Mad River downstream from the WWTP bypass (Camp Dresser \& McKee, 1997).

A basinwide assessment of recreational water quality by Ohio EPA from June to October 2003 (Ohio Environmental Protection Agency, 2005a) found elevated concentrations of fecal coliform and Esherichia coli (E. coli) bacteria throughout the study area. These elevated concentrations were primarily associated with high streamflows after precipitation events. Bacteria concentrations were especially high on Buck Creek at RM 0.60, downstream from Springfield's numerous CSOs, after a precipitation event. However, the highest median concentration of fecal coliform bacteria in the entire basin $(4,900$ $\mathrm{col} / 100 \mathrm{~mL}$ ) was found in Lily Creek.

Other potential sources of fecal coliform bacteria in the basin are discussed in the "Source Representations" section of this report. These sources include WWTP discharges and failure of a proportion of the 28,000 septic systems in the basin. Additional sources include wildlife, livestock grazing in the 18 percent of the basin that is pasture, and manure applications to land planted in row crops.

\section{Nitrate}

Because agricultural land cover is prevalent in the study area, nitrogen has been a focus of many water-quality studies in the Mad River Basin. The predominant form of nitrogen in the Mad River is dissolved nitrate (Reutter, 2003), so the following discussion includes studies that analyzed for nitrogen as well as those that analyzed for nitrate.

Rowe and others (2004) examined surface- and groundwater quality as a function of land cover in the Great Miami and Little Miami River Basins from 1999 through 2000. They found that streams draining agricultural land had the highest mean concentration of nitrogen. The major source of nitrogen in agricultural areas was attributed to commercial fertilizer and manure applications.

Reutter (2003) quantified loads of nitrogen and phosphorus in the Mad River contributed by point sources and nonpoint sources. The loads were computed by use of the ESTIMATOR program (Cohn and others, 1992) from data collected during 51 visits to the Mad River at St. Paris Pike near Eagle City streamflow gage during water years 1999 and
2000. At this location, only 2 percent of the total nitrogen load was contributed by major point-source dischargers (defined by the author as dischargers of $0.5 \mathrm{Mgal} / \mathrm{d}$ or more). Nonpoint sources and minor point sources (defined by the author as dischargers of less than $0.5 \mathrm{Mgal} / \mathrm{d}$ ) contributed 98 percent of the total nitrogen load. Even so, the nonpoint-source load reaching the Mad River represents only a fraction of the nitrogen deposited on land surface within the basin; only 18 percent of the nitrogen load from land-surface applications of manure and commercial fertilizer and from atmospheric deposition in the Mad River Basin was estimated to enter the Mad River (Reutter, 2003, p. 37). Reutter's analysis did not include contributions of nitrogen from urban runoff, CSOs, failing septic systems, or cattle in streams. Reutter also noted that, in the Mad River Basin and other drainage areas, higher median nitrogen concentrations were typically associated with higher percentages of land planted in corn and soybeans.

A significant amount of the total nitrogen load to the Mad River appears to be contributed by shallow ground water discharging to the main stem and many of the tributaries (Miami Conservancy District, 2004). Rowe and others (2004) noted a significant correlation between average nitrate ${ }^{1}$ concentration in surface water during periods of low flow and the amount of base flow for streams in the Great and Little Miami River Basins. The Mad River had both the highest average nitrate concentration and the greatest base flow compared to other streams (Rowe and others, 2004, p. 22). Reutter (2003) observed that, compared to other streams in the Great Miami River Basin, there was much less difference between minimum and maximum monthly loads of nitrate in the Mad River at St. Paris Pike. Minimum monthly loads were about 15 percent of the corresponding maximum monthly load, compared to other sites where minimums ranged from about 0.2 to 2 percent of the corresponding maximum monthly loads. It is possible that fertilizer-derived nitrogen infiltrates more quickly in the soils of the Mad River Basin, which are permeable relative to soils in other subbasins of the Great Miami River Basin (Debrewer and others, 2000) and are underlain by an extensive, highyielding aquifer composed of glacial outwash (Reutter, 2003). Therefore, less nitrogen is left at land surface to be transported to streams during runoff events. Instead, the nitrate-bearing shallow ground water continuously discharges to the Mad River as base flow, providing a stable input of nitrate to the Mad River.

Concentrations of nitrate in shallow ground water appear to be higher than those in surface water. Groundwater samples were collected from 33 wells in the Mad River Basin in summer 2003 (Miami Conservancy District, 2004). Although the median concentration for all wells was $0.5 \mathrm{mg} / \mathrm{L}$, the median concentration of nitrate for the 13 wells installed at

\footnotetext{
${ }^{1}$ Actual analyte was nitrate plus nitrite. Because nitrite concentrations are generally very small compared to nitrate in both surface water (Reutter, 2003, p. 15) and shallow ground water (U.S. Geological Survey, 2000), nitrate plus nitrite will hereafter be referred to as "nitrate" in this report.
} 
depths of $50 \mathrm{ft}$ or less was $6.0 \mathrm{mg} / \mathrm{L}$. Three samples exceeded the USEPA Maximum Contaminant Level for nitrate in drinking water $(10 \mathrm{mg} / \mathrm{L}$ as $\mathrm{N})$. Comparatively, concentrations of nitrate in surface water at the Mad River near Huffman Dam (collected in 8-hour increments between July 14 and August 18,2003 ) ranged from $1.32 \mathrm{mg} / \mathrm{L}$ to $4.06 \mathrm{mg} / \mathrm{L}$, with a median value of $3.07 \mathrm{mg} / \mathrm{L}$. Nitrate concentrations were inversely correlated to river discharge (Miami Conservancy District, 2004). Jones and others (1996) examined nitrate contamination from nonpoint sources in ground water and surface water in the Mad River Basin. They found nitrate concentrations to be routinely higher in the Kings Creek Subbasin than elsewhere in the basin.

Ohio EPA (2005a) did a basinwide assessment of fish and macroinvertebrate communities, water chemistry, and sediment chemistry in the Mad River Basin from June to October 2003. Elevated nitrate concentrations found in Kings Creek and two of its tributaries (median, $7.1 \mathrm{mg} / \mathrm{L}$ ), as well as in Dugan Run and Buck Creek above C.J. Brown Reservoir, were attributed to high volumes of ground-water inflow to streams in areas where agriculture is the predominant land cover and ground water is near land surface. Elevated nitrate concentrations in other stream reaches (St. Paris tributary to Nettle Creek, Stony Creek, and Mud Creek) were attributed to point sources. Elevated nitrate concentrations in Clear Creek (RM 0.50 , median concentration $7.45 \mathrm{mg} / \mathrm{L}$ ) may have been due to cattle in a pasture upstream from the sampling location.

\section{Simulation of Streamflow and Water Quality}

\section{Description of Model}

The HSPF model used for this study was developed with BASINS using several Geographical Information System (GIS) input datasets. The GIS datasets used to construct the model include the National Land Cover Dataset (NLCD) (U.S. Geological Survey, 1992), the National Elevation Dataset (NED) (U.S. Geological Survey, 2005a), and the National Hydrography Dataset (NHD) (U.S. Geological Survey, 2005b). Other GIS data were used to assist with model parameter estimation but were not necessary to create the model. WinHSPF version 2.3 is an interactive Windows interface to HSPF developed to assist the user in building and editing user control input (UCI) files. Furthermore, WinHSPF was used primarily for model manipulation and simulation. Use of HSPF provides a maximum amount of flexibility to address complex issues. HSPF uses hourly and (or) daily time series of rainfall and other meteorologic records to simulate the transport and storage of water and associated water-quality constituents. Precipitation can be routed from pervious and impervious land areas as a combination of surface runoff, interflow through various subsurface layers, and base flow (ground-water discharge). Assigned hydrologic response parameters (based on land cover, slope, soil properties, and other characteristics) control how precipitation is partitioned into these possible flow routes. In addition to infiltration of precipitation, the model accounts for impervious surfaces (for example, tops of buildings and pavement), interception of precipitation by plant materials before it reaches the ground, surface-detention storage, evaporation, transpiration, and storage in soil zones or ground water.

Routing of water in the stream channel is controlled by channel characteristics in each of the model subbasins. Flow in the channel is assumed to be unidirectional and to follow the kinematic wave function (Martin and McCutcheon, 1999). Inflows to each subbasin include flow from the land area (pervious and impervious) draining to that subbasin, water from upstream subbasins, precipitation falling directly on the stream surface in the subbasin, and point sources discharging to the subbasin. Outflows from a subbasin include flow to the downstream subbasin, evaporation, transpiration, loss to ground water (deep percolation), and point-source withdrawals. For each subbasin, a function table (FTABLE) summarizes the relation among water depth (stage), surface area, volume, and discharge on the basis of geometric and hydraulic properties used for channel and reservoir routing.

Only after the hydrologic model has been calibrated can water quality be accurately simulated. HSPF simulates transport and chemical reactions of constituents from land draining to a stream reach and water temperature within a reach (as well as the temperature of runoff to a reach). Chemical constituents can be transported in surface runoff, interflow, or ground water. On impervious land, constituents can accumulate on the surface and later be washed into the stream reach during a rainfall event. Predation and die-off of bacteria within the stream also can be modeled.

The HSPF model requires a significant amount of input data to effectively simulate hydrologic conditions. The input requirements consist of observed meteorologic time-series data from numerous sources, including precipitation, cloud cover, air temperature, wind movement, solar radiation, dewpoint temperature, and estimation of potential evapotranspiration. These data are assembled and stored in a binary database using watershed data management (WDM) format. The data can be created, imported, edited, displayed, and modified by use of the program/software package WDMUtil (Hummel and others, 2001). The model requires an hourly time step for the input precipitation dataset; all other datasets can be at a daily time step.

The Bacterial Indicator Tool (BIT) is a spreadsheet that was used to estimate fecal coliform contributions from multiple sources. The BIT estimates the monthly accumulation rate of fecal coliform produced by wildlife, grazing livestock, and manure applications, as well as the asymptotic limit for that accumulation should no washoff occur. The BIT also estimates the direct inputs of fecal coliform to streams from grazing animals and failing septic systems (U.S. Environmental Protection Agency, 2000b). The BIT user must supply the land-cover distribution and livestock population for each 
meteorologic zone and wildlife densities for forest, agricultural land, and pasture in the study area. The BIT user must also supply the number of septic systems, population served by septic systems, and the failure rate of septic systems in the study area. The animal-waste production rates and fecal coliform content, the fraction of each manure type applied each month, and the fraction of each manure type incorporated into the soil were default values in the BIT that were not modified for this model.

The model simulation period, January 1999 through December 2003, was selected on the basis of the availability of information for streamflow and water quality. This period includes water-quality data for simulating, calibrating, and validating the modeled results.

\section{Meteorologic Data}

Several meteorologic stations were identified in the study area. Precipitation station data from the National Oceanic and Atmospheric Administration (NOAA) and MCD were evaluated for type, length, and continuity of record, and data from four stations were selected for final application (table 4; fig. 5). These four stations were well distributed spatially, and missing data were minimal. Daily precipitation data from one NOAA station had to be disaggregated to hourly data on the basis of data from the nearest hourly precipitation station.

Other meteorologic data such as air temperature, wind movement, solar radiation, dewpoint temperature, cloud cover, and computed potential evapotranspiration were obtained from nearest first-order NOAA station; such stations are usually fully instrumented to record a complete range of meteorologic parameters. These data were acquired from NOAA station 332075 at Dayton Airport, about 5 mi west of the lower Mad River Basin.

\section{Streamflow Data}

Fifteen USGS streamflow gages are within the study area. All 15 gages were analyzed for length of record, data gaps, and basin distribution. Data from four of these gages were judged adequate for calibration of both water quantity and water quality (fig. 5). Daily streamflow data from these gages were obtained from the U.S. Geological Survey (2005c) and used for model calibration.

\section{Model Segmentation}

Segmentation of the basin is an important component of HSPF modeling for controlling parameter manipulation and assigning multiple spatially distributed input time series. The Mad River Basin was divided into 52 subbasins with drainage areas ranging from 79 to 11,355 acres. The subbasins initially consisted of 14-digit hydrologic units (HU) as defined by Seaber and others (1987). In some cases, subbasins were then further subdivided to coincide more closely with critical waterquality data collection sites and streamflow gages (fig. 6).

The model calibration and simulation process required formation of regions with homogeneous meteorologic characteristics for input of meteorologic time series. These regions are referred to as "meteorologic zones." Four meteorologic zones were constructed for the hydrologic simulation by grouping subbasins on the basis of centroid location relative to precipitation station thiessen-polygon coverage area. To facilitate adjustment of parameters for water-quality modeling, it was necessary to subdivide the original four meteorologic zones further, resulting in a total of nine meteorologic zones (fig. 7). The additional five meteorologic zones retain the initial meteorologic time-series definition and precipitation correction factors.

Table 4. Annual and total precipitation at meterological stations near the Mad River basin, 1999-2003.

[NOAA, National Oceanic and Atmospheric Administration; MCD, Miami Conservancy District]

\begin{tabular}{lccccccc}
\hline \multicolumn{1}{c}{ Station } & $\begin{array}{c}\text { Correction } \\
\text { factor }\end{array}$ & $\mathbf{1 9 9 9}$ & $\mathbf{2 0 0 0}$ & $\mathbf{2 0 0 1}$ & $\mathbf{2 0 0 2}$ & $\mathbf{2 0 0 3}$ & Total \\
\hline 330563 NOAA - Belfontaine & 1.05 & 36.2 & 44.6 & 43.6 & 42.7 & 54.2 & 221.3 \\
5000 MCD - Springfield & 1.00 & 27.6 & 41.8 & 46.5 & 44.3 & 51.2 & 211.4 \\
5020 MCD - Urbana & 1.12 & 29.1 & 41.0 & 41.6 & 40.5 & 51.6 & 203.8 \\
332075 NOAA - Dayton Airport & 1.00 & 28.2 & 33.7 & 42.2 & 38.7 & 44.0 & 186.8 \\
\hline
\end{tabular}




\section{EXPLANATION}

Precipitation station and station identification number

U USGS streamflow gage and 8-digit identification number

Mad River

Tributary stream

C Mad River Basin

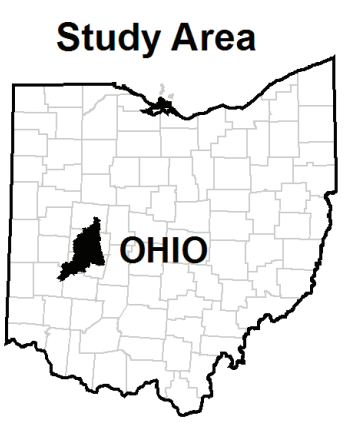

332075

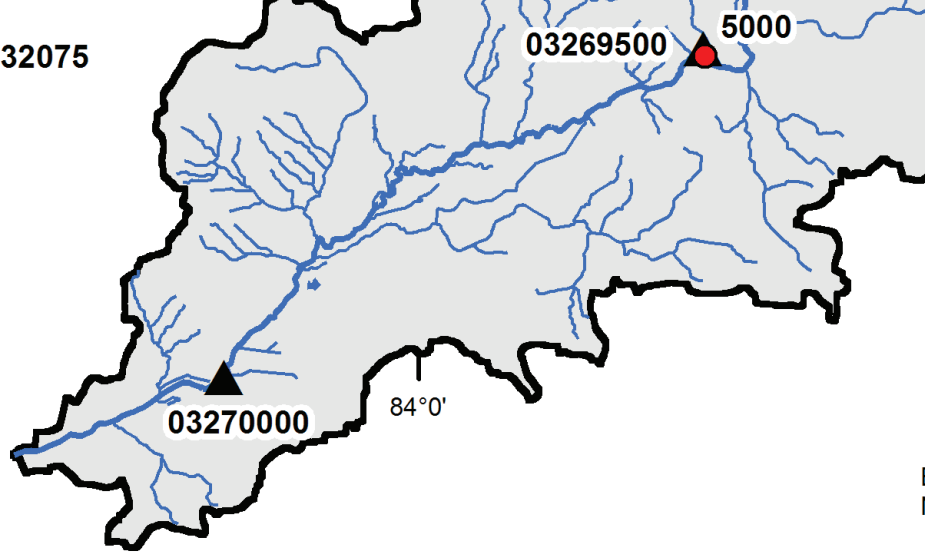

Base from U.S. Geological Survey digital data

NAD83, Universal Transverse Mercator projection, Zone 17

Figure 5. Location of streamflow gages and precipitation stations used for construction of the hydrologic model of Mad River Basin. (Station names given in tables 4 and 5.) 


\section{EXPLANATION}

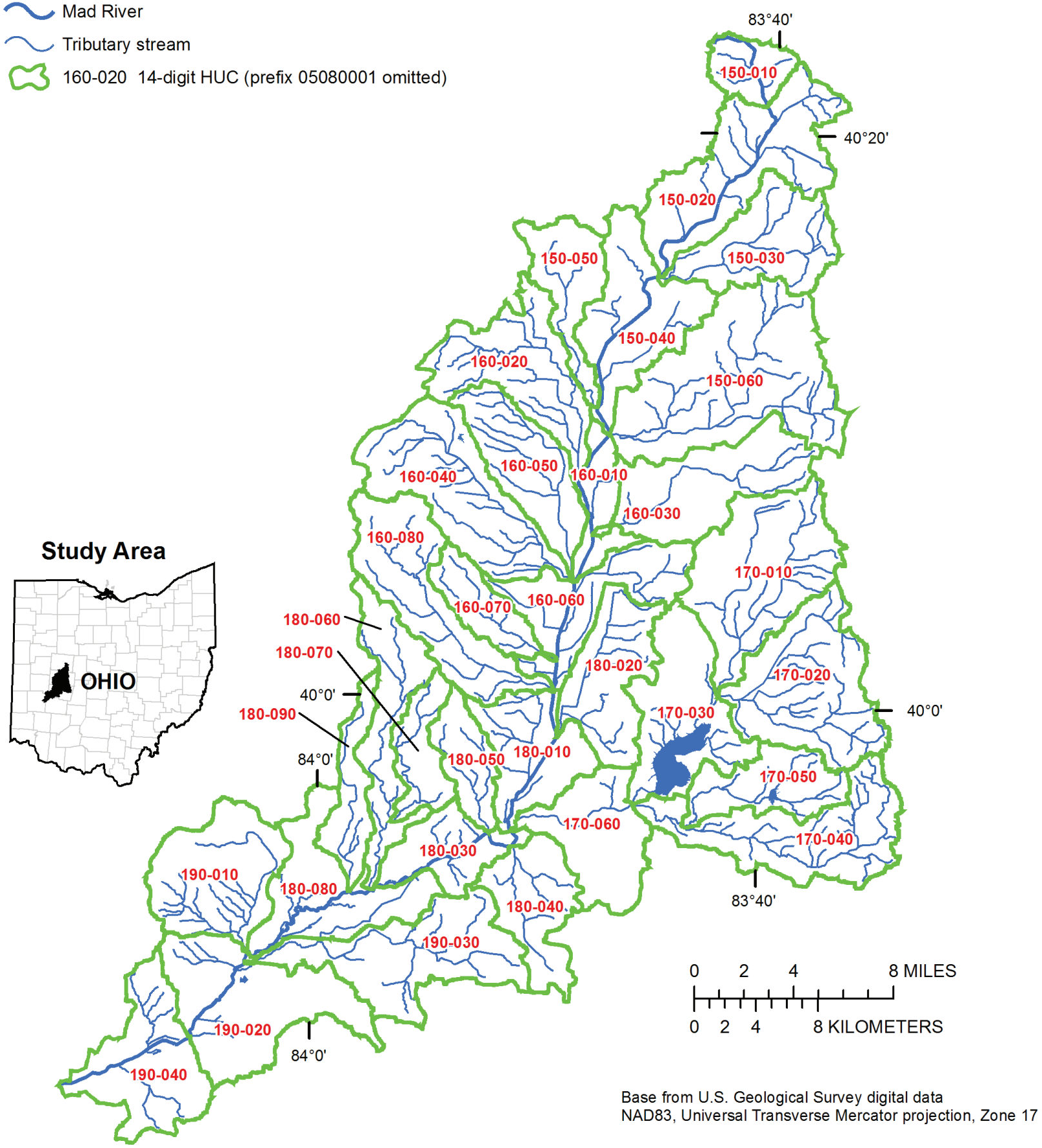

Figure 6. Location of 14-digit hydrologic units (HUs) in Mad River Basin. (HUC data from U.S. Department of Agriculture, 1991b.) 


\section{EXPLANATION}
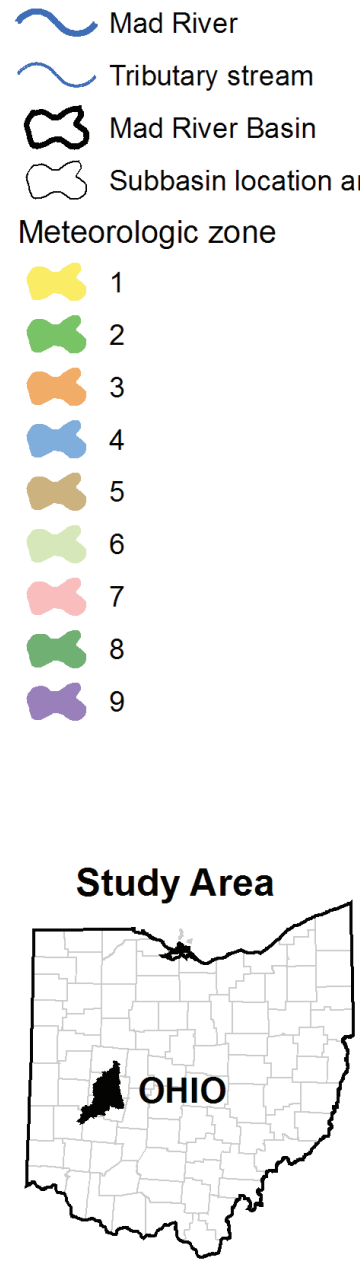

ad River

3 Mad River Basin

$\widetilde{3}$ Subbasin location and identification number Meteorologic zone

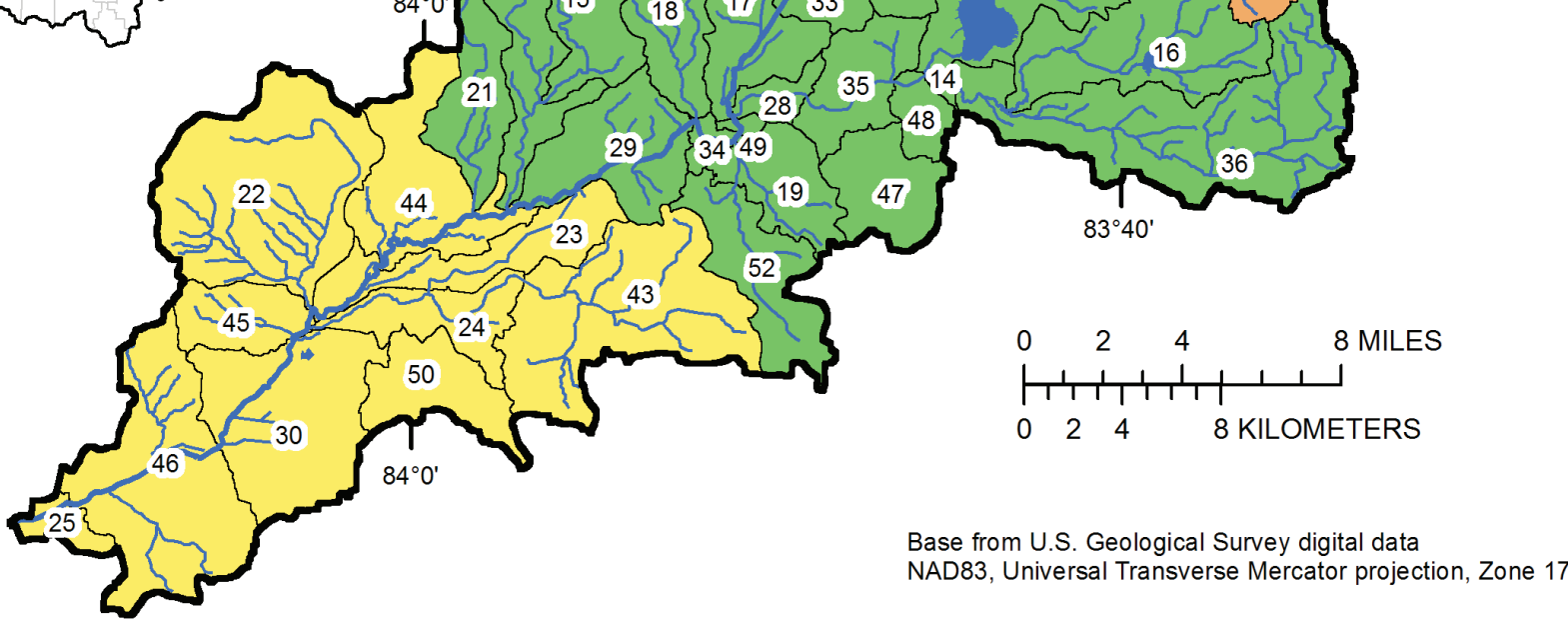

Figure 7. Location of 52 modeled subbasins and 9 meteorologic zones in the Mad River Basin. 


\section{Model Limitations}

The hydrologic model constructed for this study was developed to simulate daily mean discharge and ultimately to estimate water-quality loads of fecal coliform bacteria and nitrate. The calibration and simulation were prepared to support the specific requirements of this study.

HSPF models have the potential to be used for many water-resource management applications. This model was constructed specifically for simulating daily streamflow and constituent loading in the Mad River Basin. Therefore, use of this model for other applications could produce inaccurate or deceiving hydrologic response and results. Uses of the model outside the constraints of this study could require additional calibration and (or) parameter modification.

\section{Hydrologic Simulation}

Hydrologic simulation combines the physical characteristics of the watershed and the observed meteorologic data series to produce the simulated hydrologic response (Donigian, 2002). Daily mean streamflows were simulated for the period January 1999 to December 2003. This 5-year period comprises sufficient data to evaluate parameters within a variety of hydrologic conditions (Donigian, 2002). Subbasin characteristics such as channel slope, average land slope, and depth-volume relation were computed by extracting information from the 30-meter NED (U.S. Geological Survey, 2005a). The NED also aided in producing the FTABLEs discussed previously.

The land-cover characteristics for each subbasin were differentiated by 14 land-cover classes from the National Land Cover Dataset (U.S. Geological Survey, 1992). These classes were analyzed and aggregated into eight general categories based on hydrologic response similarities (table 3). The contribution of impervious land cover in the model was estimated by applying a percentage of impervious surface based on the land-cover class and amount of effective imperviousness. The percent impervious area used in this study was based on final calibrated percentages derived from similar land-cover classes in a study reported by Zarriello and Ries (2000) (table 3). Appendix 1 details land-cover information for the 14-digit Hydrologic Unit and subbasin boundaries used in the model.

\section{Hydrologic Calibration}

The Mad River Basin model was calibrated for the 4-year period January 1, 1999, through December 31, 2002; results were output at a daily time step. The calibration approach used for this study included use of GenScn (Kittle and others, 1998) for comparing observed and simulated results and HSPEXP (Lumb and others, 1994), an expert system for hydrologic calibration that incorporates parameter-adjustment assistance and comparative statistics.

The hydrologic calibration for this study involved examination of the following model response characteris- tics: (1) annual water balance and volume, (2) monthly and seasonal flow volume, (3) base flow, and (4) storm volume. The calibration focus was aimed at providing accurate flow simulations, especially for the annual period and the recreational season (May 1 through October 15) so that constituent loading also could be simulated accurately. The observed and simulated values for these flow characteristics were compared and parameters were adjusted iteratively by use of HSPEXP and manual edits until simulated values met the acceptable criteria chosen for this study. Parameters were modified for each meteorologic zone to simulate surface runoff, interflow, base flow, and total runoff. Values of the principal hydrologic parameters modified during calibration are listed in Appendix 2. The comparison of simulated and observed streamflow included evaluation of total volume; seasonal volume; storm volume for normal, low, and high flow regimes; seasonal variability; and 20 selected storm events. Plots of daily mean streamflow were used to compare simulated and observed results for the calibration time period (fig. 8). Flow-duration plots of simulated flows are reasonable in comparison to the observed flows during the calibration period (fig. 9). Table 5 lists the streamflow calibration results for the 4-year period, including the acceptable criteria used in this study.

In addition to model-parameter adjustment, precipitation data were adjusted by the use of a correction factor or multiplier to account for under-registering of precipitation gages with a tipping-bucket mechanism (Kuligowski, 1997). The precipitation correction factors ranged from 1.0 to 1.12 for hourly values (table 4, p. 13). The final determination of the correction factor was derived from an annual volume calibration for four USGS streamflow gages.

The large base-flow component of the Mad River required use of the upper range of parameter values for the AGWRC parameter (ground-water recession rate) to accurately simulate hydrograph-recession characteristics. A quantitative analysis of surface runoff and base flow to gross streamflow was documented in a USGS study (Koltun, 1995). Table 6 lists the percentage difference between modeled median annual base flow and results from Koltun (1995) for the four streamflow gages in the Mad River Basin. In addition, interflow and surface-runoff annual contribution to total simulated flow ranged from 23.0 to 26.3 percent and 5.3 to 9.9 percent, respectively. However, flow contribution from interflow and surface runoff for individual storm events varied widely depending on antecedent moisture condition, precipitation intensity, storage capacity, infiltration capacity, and other factors.

The model was validated by simulating streamflow for calendar year 2003. Once parameter values were established for the calibration period, the model was rerun by including calendar year 2003. Annual streamflow statistics and validation results for the four streamflow gages are listed in table 5 . The calibration and validation aggregate simulation periods explain the total error, whereas the annual statistics are evidence of the accuracy. Verification of streamflow response was acceptable by meeting either of the two criteria for the 

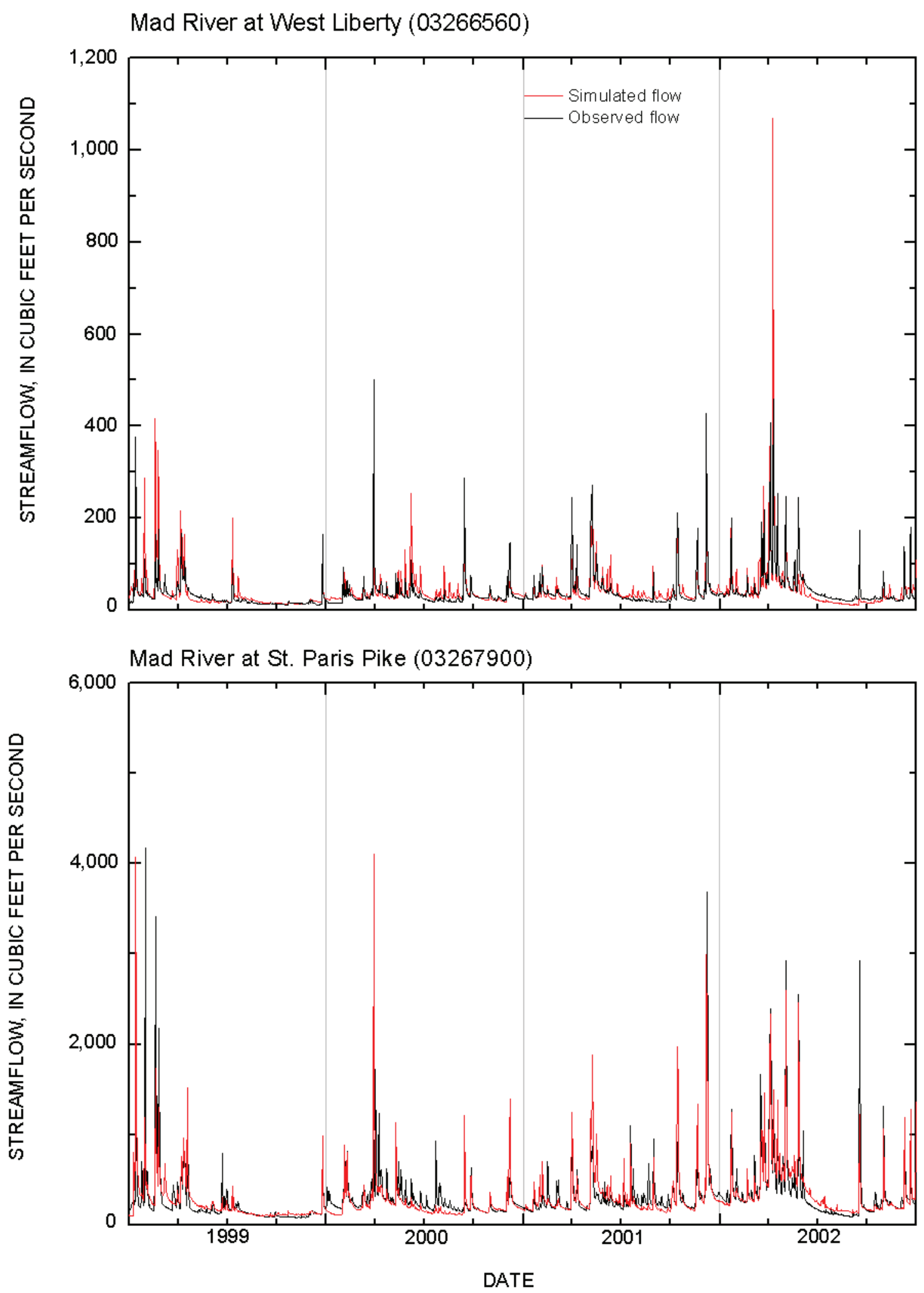

Figure 8a. Relation of simulated daily mean streamflow to observed daily streamflow for Mad River at West Liberty (03266560) and Mad River at St. Paris Pike (03267900), January 1, 1999, through December 31, 2003. 

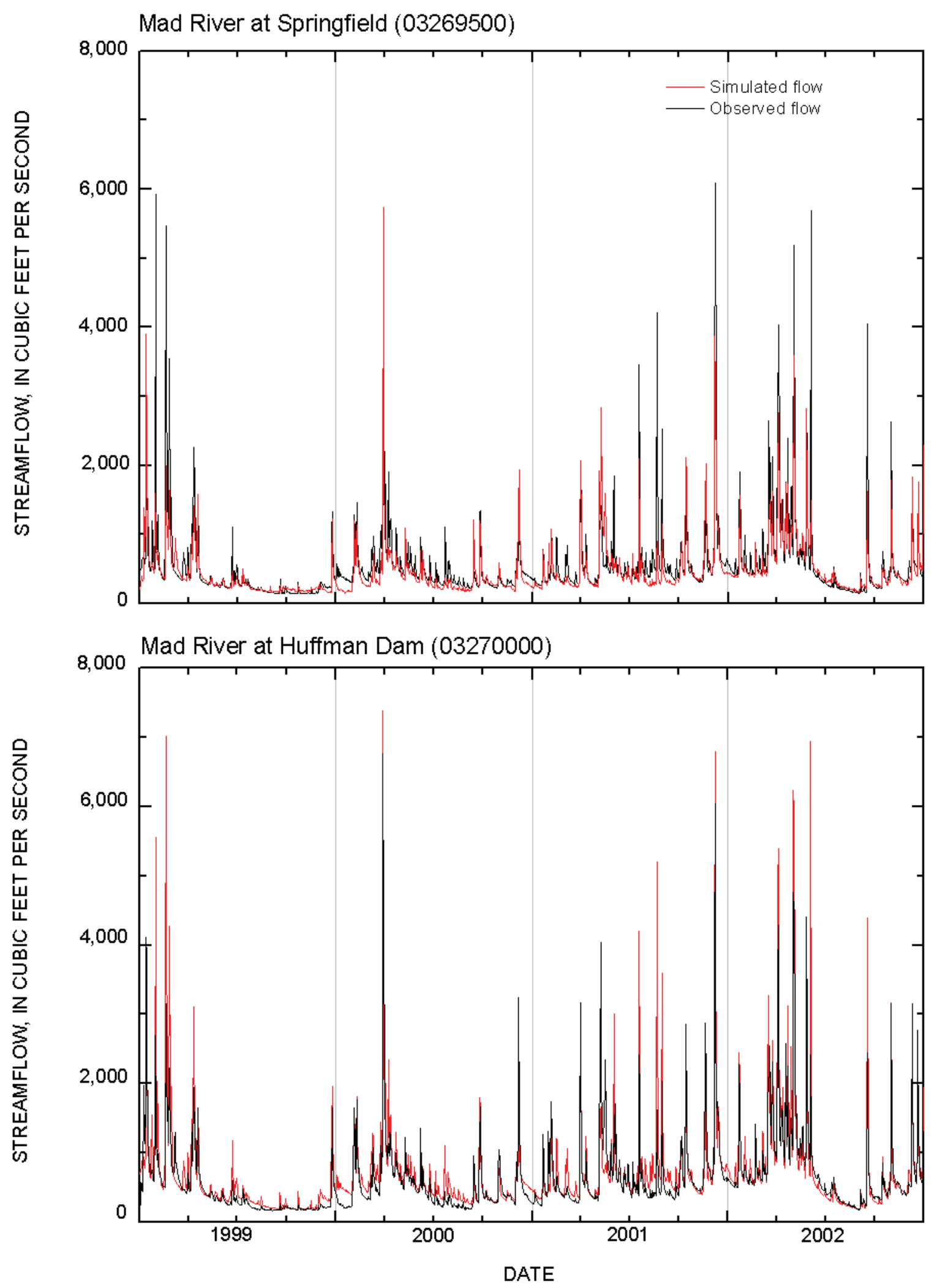

Figure 8b. Relation of simulated daily mean streamflow to observed daily streamflow for Mad River at Springfield (03269500) and Mad River at Huffman Dam (03270000), January 1, 1999, through December 31, 2003. 

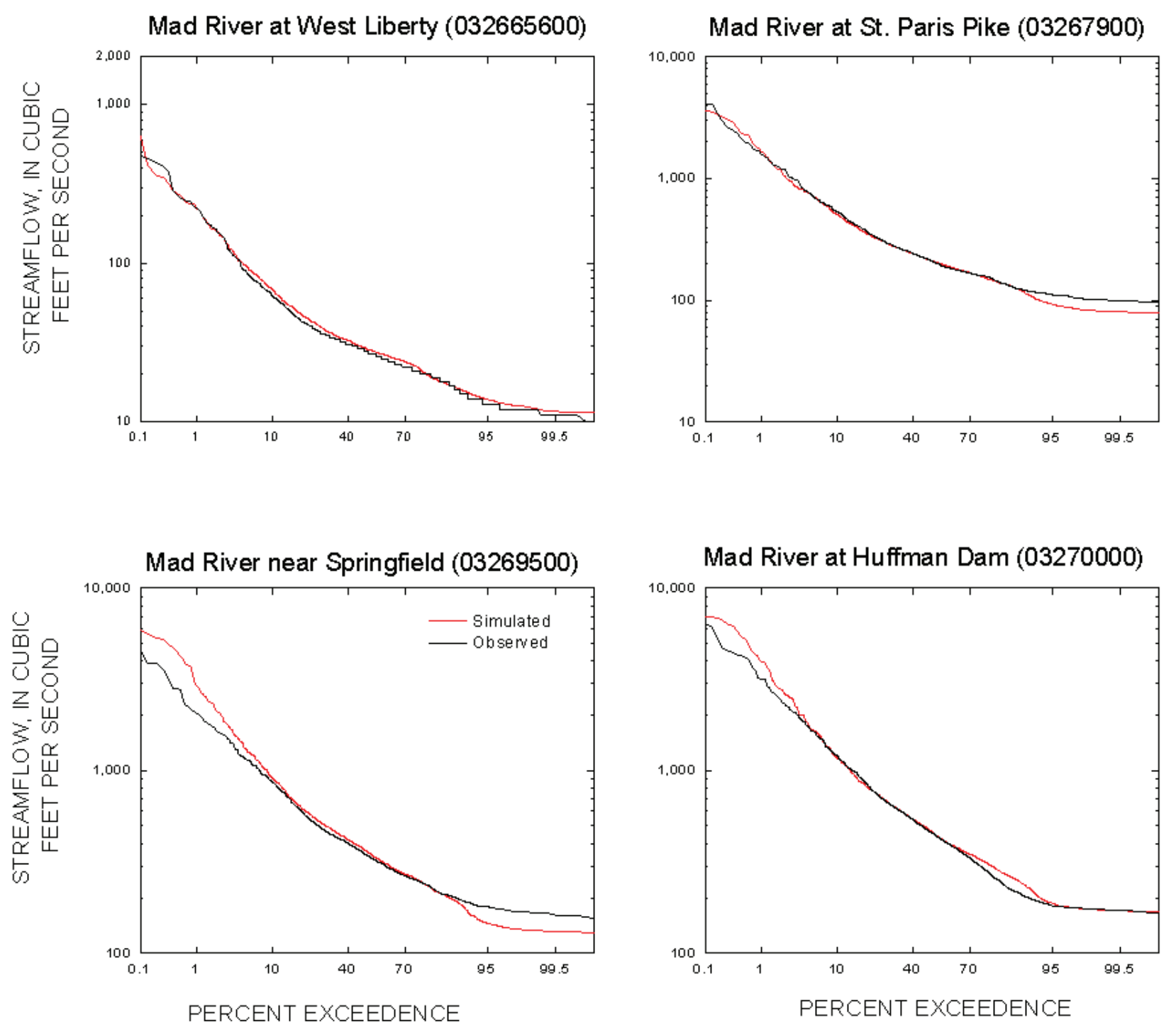

Figure 9. Flow-duration curves of simulated and observed streamflows for Mad River at West Liberty (03266560), Mad River at St. Paris Pike (03267900), Mad River near Springfield (03269500), and Mad River at Huffman Dam (03270000), 1999-2003.

simulation that included 2003. First, the validation period error should fit within the minimum and maximum annual error of the calibration period. Second, the absolute error in the validation period and the aggregate period, 1999-2003, should meet the 1999-2002 calibration criteria. Results for streamflow gage 03266560 show minor exceedance of these criteria for storm volumes and peak streamflow; however, of the four streamflow gages used for the model, this station has the smallest contributing drainage area $\left(36.6 \mathrm{mi}^{2}\right)$, making it potentially more sensitive to precipitation input and prone to greater simulation error. Comparison of the simulated and observed streamflow results for these periods indicated that simulation errors were generally within the calibration criteria chosen for the model.
In conclusion, model parameters calibrated on data for the period 1999 through 2002 appear to result in acceptable simulations of other adjacent time periods. The HSPF model is mostly controlled by land-cover characteristics and the parameter values for each land-cover class within a meteorologic zone. Furthermore, it is expected that model-simulation results would be similar for times near the calibration period and (or) land cover that is not significantly different from that represented by the NLCD dataset. Values of the principal parameters used to calibrate the model for streamflow simulation are listed in Appendix 2. 
Table 5. Calibration criteria, simulation error, and validation results at four streamflow gages in the Mad River Basin.

$\left[\mathrm{mi}^{2}\right.$, square miles; positive error means the simulated value is greater than the observed value]

\begin{tabular}{|c|c|c|c|c|c|c|c|c|}
\hline & & $\begin{array}{l}\text { Error } \\
\text { in total } \\
\text { volume } \\
(\%)\end{array}$ & $\begin{array}{c}\text { Seasonal } \\
\text { volume } \\
\text { error }(\%)\end{array}$ & $\begin{array}{c}\text { Error in } \\
50 \% \text { low- } \\
\text { est flows } \\
(\%)\end{array}$ & $\begin{array}{c}\text { Error in } \\
\text { storm } \\
\text { volumes } \\
(\%)\end{array}$ & $\begin{array}{c}\text { Summer } \\
\text { storm } \\
\text { volume } \\
\text { error }(\%)\end{array}$ & $\begin{array}{c}\text { Average } \\
\text { storm peak } \\
\text { flow error } \\
(\%)\end{array}$ & $\begin{array}{c}\text { Error in } \\
10 \% \text { high- } \\
\text { est flows } \\
(\%)\end{array}$ \\
\hline 1999-2002 Calibration criteria & & 10 & 10 & 10 & 15 & 20 & 25 & 25 \\
\hline \multicolumn{9}{|c|}{03266560 Mad River at West Liberty, subbasin 31 (area, $36.6 \mathrm{mi}^{2}$ ) } \\
\hline \multirow{4}{*}{ Individual-year calibration } & 1999 & 22.8 & 19.4 & 10.6 & 27.2 & -51.6 & 0.9 & 59.9 \\
\hline & 2000 & 12.9 & 58.5 & 20.1 & -18.7 & 172.1 & -23.6 & -1.9 \\
\hline & 2001 & 3.1 & 30.1 & 16.1 & -18.7 & 56.3 & -27.9 & -13.0 \\
\hline & 2002 & -6.9 & 50.4 & -23.1 & -26.1 & -37.0 & -35.9 & 2.0 \\
\hline Aggregate results & 1999-2002 & 5.8 & 0.7 & 4.5 & -10.0 & -10.9 & -23.7 & 5.6 \\
\hline \multirow{3}{*}{$\begin{array}{l}\text { Summary statistics for 1999-2002 } \\
\text { calibration }\end{array}$} & Minimum & -6.9 & 19.4 & -23.1 & -26.1 & -51.6 & -35.9 & -13.0 \\
\hline & Maximum & 22.8 & 58.5 & 20.1 & 27.2 & 172.1 & 0.9 & 59.9 \\
\hline & Median & 8.0 & 40.2 & 13.3 & -18.7 & 9.6 & -25.7 & 0.0 \\
\hline Validation results & 2003 & -6.6 & 25.5 & -5.4 & -28.6 & 32.0 & -37.1 & -5.2 \\
\hline Aggregate validation results & $1999-2003$ & 2.1 & 8.6 & 3.9 & -16.9 & 6.0 & -27.5 & 0.6 \\
\hline \multicolumn{9}{|c|}{03267900 Mad River at St. Paris Pike, subbasin 33 (area, $310 \mathrm{mi}^{2}$ ) } \\
\hline \multirow{4}{*}{ Individual-year calibration } & 1999 & -6.8 & 11.8 & -9.9 & -15.5 & -8.3 & -15.6 & 5.3 \\
\hline & 2000 & 9.7 & 50.2 & 19.5 & -31.9 & 100.8 & -42.4 & -9.7 \\
\hline & 2001 & -5.2 & 1.3 & 2.4 & -16.0 & 61.9 & -10.8 & -14.0 \\
\hline & 2002 & -2.6 & 33.2 & -14.3 & 25.7 & -23.8 & 19.3 & 13.6 \\
\hline Aggregate results & 1999-2002 & -1.6 & 1.6 & -1.7 & -7.9 & 20.0 & -10.1 & -1.2 \\
\hline \multirow{3}{*}{$\begin{array}{l}\text { Summary statistics for 1999-2002 } \\
\text { calibration }\end{array}$} & Minimum & -6.8 & 1.3 & -14.3 & -31.9 & -23.8 & -42.4 & -14.0 \\
\hline & Maximum & 9.7 & 50.2 & 19.5 & 25.7 & 100.8 & 19.3 & 13.6 \\
\hline & Median & -3.9 & 22.5 & -3.8 & -15.8 & 26.8 & -13.2 & -2.2 \\
\hline Validation results & 2003 & 6.9 & 5.5 & -4.2 & 10.3 & 17.5 & 3.1 & 28.4 \\
\hline Aggregate validation results & $1999-2003$ & 0.8 & 1.7 & -1.3 & -1.9 & 20.0 & -7.2 & 7.3 \\
\hline \multicolumn{9}{|c|}{03269500 Mad River near Springfield, subbasin 34 (area, $490 \mathrm{mi}^{2}$ ) } \\
\hline \multirow{4}{*}{ Individual-year calibration } & 1999 & 10.2 & 12.9 & -10.9 & 12.4 & -24.2 & 27.7 & 29.9 \\
\hline & 2000 & 12.5 & 12.8 & 13.7 & 0.0 & 32.1 & -12.1 & 11.0 \\
\hline & 2001 & 6.9 & 21.9 & 7.4 & 0.4 & 74.1 & 17.6 & 9.4 \\
\hline & 2002 & 9.1 & 17.1 & -14.3 & 33.4 & -32.7 & 36.2 & 39.6 \\
\hline Aggregate results & 1999-2002 & 9.5 & 1.6 & -0.5 & 11.4 & 10.6 & 17.3 & 22.5 \\
\hline \multirow{3}{*}{$\begin{array}{l}\text { Summary statistics for } 1999-2002 \\
\text { calibration }\end{array}$} & Minimum & 6.9 & 12.8 & -14.3 & 0.0 & -32.7 & -12.1 & 9.4 \\
\hline & Maximum & 12.5 & 21.9 & 13.7 & 33.4 & 74.1 & 36.2 & 39.6 \\
\hline & Median & 9.7 & 15.0 & -1.7 & 6.4 & 4.0 & 22.7 & 20.4 \\
\hline Validation results & 2003 & 3.9 & 2.8 & -8.7 & 7.2 & 20.9 & 16.8 & 36.7 \\
\hline Aggregate validation results & $1999-2003$ & 7.9 & 2.8 & 0.6 & 10.0 & 14.3 & 17.2 & 25.0 \\
\hline \multicolumn{9}{|c|}{03270000 Mad River near Dayton, subbasin 30 (area, $\left.635 \mathrm{mi}^{2}\right)$} \\
\hline \multirow{4}{*}{ Individual-year calibration } & 1999 & 17.5 & 4.7 & 17.4 & 5.8 & -0.2 & 29.8 & 20.6 \\
\hline & 2000 & 5.7 & 17.6 & 16.1 & -10.4 & -1.1 & -15.0 & -0.3 \\
\hline & 2001 & 1.2 & 17.1 & 6.1 & -5.2 & 52.1 & -4.8 & 1.2 \\
\hline & 2002 & -0.7 & 9.2 & -17.4 & 11.3 & -15.4 & 7.7 & 16.1 \\
\hline Aggregate results & $1999-2002$ & 4.6 & 4.9 & 6.0 & 0.8 & 8.3 & 2.4 & 9.3 \\
\hline \multirow{3}{*}{$\begin{array}{l}\text { Summary statistics for 1999-2002 } \\
\text { calibration }\end{array}$} & Minimum & -0.7 & 4.7 & -17.4 & -10.4 & -15.4 & -15.0 & -0.3 \\
\hline & Maximum & 17.5 & 17.6 & 17.4 & 11.3 & 52.1 & 29.8 & 20.6 \\
\hline & Median & 3.4 & 13.2 & 11.1 & 0.3 & -0.6 & 1.4 & 8.7 \\
\hline Validation results & 2003 & -8.1 & 7.8 & -13.8 & -5.6 & 30.4 & -4.2 & 11.2 \\
\hline Aggregate validation results & $1999-2003$ & 0.9 & 5.5 & 3.6 & -1.3 & 15.4 & 0.9 & 8.2 \\
\hline
\end{tabular}


Table 6. Comparison of simulated and estimated median annual base flow, 1999-2002.

[Base-flow estimates from Koltun (1995); negative percent difference means estimated value greater than simulated value]

\begin{tabular}{cccc}
\hline & \multicolumn{2}{c}{ Median of annual base flow, in inches } & \\
\cline { 2 - 3 } USGS station number & Simulated & Estimated & Percent difference \\
\hline 3266560 & 8.98 & 9.05 & -0.8 \\
3267900 & 9.00 & 10.10 & -10.9 \\
3269500 & 8.88 & 9.26 & -4.1 \\
3270000 & 8.75 & 9.07 & -3.5 \\
\hline
\end{tabular}

Table 7. Sensitivity of modeled runoff characteristics at gaging station 03270000 to variations in selected hydrologic model parameters for the period 1999-2002.

[Positive error means the simulated value is greater than the observed value. AGWRC, active ground-water recession rate; INFILT, infiltration capacity of the soil; INTERCEP, interception storage capacity; INTFW, interflow coefficient; KVARY, ground-water recession flow parameter; LSUR, length of the overland flow plane; LZETP, lower zone evapotranspiration parameter; LZETPARM, lower zone evapotranspiration; LZSN, lower zone nominal storage; UZSN, upper zone nominal storage]

\begin{tabular}{|c|c|c|c|c|c|c|c|c|}
\hline & & $\begin{array}{l}\text { Error in to- } \\
\text { tal volume } \\
\quad(\%)\end{array}$ & $\begin{array}{c}\text { Seasonal } \\
\text { volume } \\
\text { error }(\%)\end{array}$ & $\begin{array}{c}\text { Error in } \\
50 \% \text { low- } \\
\text { est flows } \\
(\%)\end{array}$ & $\begin{array}{c}\text { Error in } \\
\text { storm } \\
\text { volumes } \\
(\%)\end{array}$ & $\begin{array}{c}\text { Summer } \\
\text { storm } \\
\text { volume } \\
\text { error }(\%)\end{array}$ & $\begin{array}{c}\text { Average } \\
\text { storm } \\
\text { peak flow } \\
\text { error (\%) }\end{array}$ & $\begin{array}{c}\text { Error in } \\
10 \% \text { high- } \\
\text { est flows } \\
(\%)\end{array}$ \\
\hline & $\begin{array}{c}\text { Calibration } \\
\text { criteria }\end{array}$ & 10 & 10 & 10 & 15 & 20 & 25 & 25 \\
\hline & $\begin{array}{c}\text { Calibrated } \\
\text { model error }\end{array}$ & 4.6 & 4.9 & 6.0 & 0.8 & 8.3 & 2.4 & 9.3 \\
\hline Parameter & Multiplier & & & & & & & \\
\hline AGWRC & 0.9 & 17.4 & 87.9 & -43.9 & 25.4 & -13.8 & 20.2 & 77.1 \\
\hline INFILT & 2 & 7.1 & 14.6 & 21.0 & -14.8 & 11.9 & -22.4 & -4.8 \\
\hline INFILT & 0.5 & 4.1 & 3.8 & -6.3 & 17.3 & 6.1 & 31.9 & 26.1 \\
\hline INTERCEP & 2 & 2.2 & 0.6 & 2.1 & 0.9 & 6.6 & 2.9 & 9.0 \\
\hline INTERCEP & 0.5 & 6.2 & 8.6 & 8.7 & 0.6 & 9.0 & 2.0 & 9.4 \\
\hline INTFW & 2 & 5.3 & 4.7 & 5.6 & 1.0 & 5.5 & -5.4 & 8.6 \\
\hline INTFW & 0.5 & 4.1 & 6.2 & 5.1 & 4.1 & 11.5 & 11.8 & 12.9 \\
\hline KVARY & 2 & 9.6 & 3.5 & 5.2 & 5.3 & 4.7 & 4.6 & 14.3 \\
\hline KVARY & 0.5 & -0.9 & 9.1 & 2.8 & -2.9 & 9.9 & 0.4 & 5.4 \\
\hline LSUR & 2 & 4.3 & 4.5 & 6.6 & -1.3 & 6.8 & -2.6 & 6.9 \\
\hline LSUR & 0.5 & 5.0 & 5.4 & 5.2 & 3.6 & 12.0 & 8.3 & 12.6 \\
\hline LZETP & 2 & 4.6 & 4.9 & 6.0 & 0.8 & 8.3 & 2.4 & 9.3 \\
\hline LZETP & 0.5 & 4.6 & 4.9 & 6.0 & 0.8 & 8.3 & 2.4 & 9.3 \\
\hline LZETPARM & 2 & -3.9 & 4.9 & -3.9 & -9.1 & 7.2 & -8.9 & 1.3 \\
\hline LZETPARM & 0.5 & 19.4 & 2.1 & 20.1 & 22.3 & 7.0 & 27.7 & 28.6 \\
\hline LZSN & 2 & -5.1 & 23.4 & 3.8 & -17.0 & 23.6 & -17.7 & -8.6 \\
\hline LZSN & 0.5 & 10.4 & 14.4 & 2.4 & 16.3 & -10.1 & 21.3 & 25.9 \\
\hline UZSN & 2 & -6.6 & 21.5 & 5.0 & -24.3 & 23.2 & -28.4 & -13.9 \\
\hline UZSN & 0.5 & 15.7 & 12.6 & 6.5 & 32.0 & -3.7 & 42.9 & 35.4 \\
\hline
\end{tabular}




\section{Sensitivity Analysis}

A sensitivity analysis illustrates the response of a model to modifications of input values. The sensitivity analysis was done by varying the principal hydrologic input parameters by fixed percentages from their calibrated values and recording the corresponding change in simulated flow characteristics relative to those determined from the calibrated model. Table 7 (p. 22) lists the relative changes in volumes and flows resulting from adjustment of each parameter. In some cases, changes in the simulation results due to parameter modifications were small because the model is relatively insensitive to changes in the parameter or the model parameter itself was constrained in some way. For example, the parameter value for AGWRC was near or at the maximum allowable model value, so an increased AGWRC had virtually no effect on the simulation results; however, decreasing the AGWRC value had a significant effect on flow, especially the low-flow regime. Adjustment of the INFILT (infiltration capacity of the soil) had a smaller effect on volume and a considerable effect on storm-event peak flow. Simulated high flow, storm volume, and storm peak are sensitive to changes to the parameters LZETPARM (lower zone evapotranspiration), LZSN (lower zone nominal storage), and UZSN (upper zone nominal storage).

\section{Assumptions}

Streamflow simulations include the following assumptions:

- Each subbasin within a meteorologic zone has a similar hydrologic response to the input data.

- Daily precipitation disaggregated into an hourly time series are sufficiently accurate.

- Precipitation data are accurate in amount and in spatial and temporal distribution.

- Meteorologic data other than precipitation are representative for all meteorologic zones.

- Differences between land-cover characteristics determined from the NLCD (near 1992) and the actual land-cover characteristics during the calibration period (1999-2002) minimally affect simulation results.

- Parameters for pervious and impervious land areas are representative of the designated meteorologic zone.

\section{Water-Quality Simulation}

The HSPF model was used to simulate water quality from 1999 through 2003 for each of the 52 subbasins within the Mad River Basin. The HSPF model is able to account for the movement of fecal coliform and nitrate from the land surface to the streams and through the stream network. The PQUAL module (for the pervious land segments) and the IQUAL module (for the impervious land segments) were used to simulate the transport of the constituents to the streams. The RCHRES module was then used to simulate the transport of fecal coliform and nitrate through the stream network.

The PQUAL module simulates storages and fluxes of fecal coliform and nitrate by means of surface runoff, interflow, and base flow. The deposition of these constituents onto the surface is first defined in the PQUAL module by the monthly accumulation rates (MON-ACCUM). (Nitrate from the atmosphere is another source of deposition used in the model, but it is not a component of the PQUAL module). Fecal coliform and nitrate accumulate on the surface until a monthly storage limit (MON-SQOLIM) has been reached. Fecal coliform is removed from surface storage by either die-off or washoff. The removal rate (REMQOP) of the stored fecal coliform through die-off is defined by the ratio of the monthly accumulation rate (MON-ACCUM) and the monthly storage limit (MON-SQOLIM). Nitrate and the remaining fecal coliform are removed from surface storage by overland flow. The transport of fecal coliform and nitrate by overland flow (SOQUAL) is controlled in the model by the amount of overland flow (SURO) and the susceptibility of these constituents to washoff by overland flow (WSFAC).

The IQUAL module simulates storages and fluxes of fecal coliform and nitrate by means of surface runoff only. The transport processes through washoff are the same in the IQUAL module as those described for the PQUAL module; however, fecal coliform and nitrate stored on an impervious land segment are generally more susceptible to washoff than those stored on pervious land segments. Because of this, the WSFAC for impervious land segments is greater than that for pervious land segments.

A given constituent enters a stream segment from the permeable and impermeable land segments, point sources, and any upstream stream segments. Once the constituent is in the stream segment, the RCHRES module is used in this model to simulate its transport though a stream segment and on to the next downstream stream segment. The RCHRES module also simulates the die-off of fecal coliform within the stream segments with a first-order decay rate (FSTDEC). Additional information on the HSPF model processes used to simulation fecal coliform and nitrate can be found in Bicknell and others (1997).

\section{Source Representations}

As specified by Ohio EPA, this study addresses nutrient enrichment (specifically, nitrate) as one of the primary stressors impairing beneficial uses in the Mad River Basin. Also addressed are fecal coliform loads, which have caused some stream segments to be impaired for recreational use. Point sources, such as wastewater-treatment plants (WWTPs) and CSOs, discharge to the Mad River and its tributaries and are likely sources of both nitrate and fecal coliform. However, 
more diffuse (nonpoint) sources, such as urban and agricultural runoff, ground water contributions, livestock and wildlife, and atmospheric deposition account for the most of the nitrate load to the Mad River (Reutter, 2003). Quantification of sources fecal coliform and nitrate are discussed below.

Point sources included in the model were discharges from WWTPs and CSOs. Failed septic systems, atmospheric deposition (wet and dry sources), and cattle in streams are nonpoint sources that were also included in the model. These constituent sources were stored in the watershed data management (WDM) format, which could be read by the HSPF model. The WDMUtil program was used to create, import, edit, display, and modify these source load files. These sources are then directly input into the targeted stream segment (RCHRES).

Fertilizer and manure applications were not directly input to the HSPF model but were simulated by adjustment of model parameter values such as monthly maximum storage capacities of a constituent, monthly accumulation rates of a constituent, and monthly ground-water and interflow concentrations of a constituent.

\section{Wastewater-Treatment Plants}

The USEPA regulates discharges from municipal and industrial wastewater-treatment plants under the National Pollutant Discharge Elimination System (NPDES) permit program. Allowable pollutant loads and maximum allowable concentrations of pollutants in effluent water discharged to a stream are dictated by the NPDES permit (U.S. Environmental Protection Agency, 2003). In Ohio, this program is administered by the Ohio EPA. Table 8 lists NPDES-permitted facilities for which effluent data were provided by the Ohio EPA; these discharges were included in the HSPF model. The median discharge for the period from 1999 through 2004 is also listed along with its receiving stream. Although 2004 was not used to calibrate the HSPF model, this year was included in table 8 to provide a more complete representation of the discharge information. Facility locations are plotted on figure 10. The Springfield WWTP is the largest discharger in the basin, contributing almost 65 percent of the total median discharge (1999 through 2004) from the permitted point sources included in this study (table 8).

Monthly loads of fecal coliform and nitrate were computed from January 1999 through October 2004 for each of the 32 WWTPs listed in table 8. These loads were computed from concentration and discharge data provided by the Ohio EPA for this study. This information is available from the Monthly Operating Reports (MORs) that the permitted facilities are required to submit to the Ohio EPA. In cases where MOR data were incomplete, missing monthly loads were substituted with loads computed from the overall median of the nitrate concentration or the geometric mean of the fecal coliform count computed from the facility's available data. Many smaller discharge facilities were not required by the Ohio EPA to report fecal coliform and (or) nitrate data in their MOR. For nonindustrial facilities, the nitrate median concen- tration or the fecal coliform geometric mean computed from the other nonindustrial facilities in the study area were used as substitute concentrations of the unrecorded constituent. Loads were then computed using the substituted concentration with the recorded discharge for that facility. Discharges from some industrial plants and Wright-Patterson Air Force Base were excluded from this model because fecal coliform and nitrate data were not required in their MORs. (The MORs from these facilities are typically used to monitor constituents such as dissolved metals and organic compounds in these discharges.) In addition, Ohio EPA does not require discharge facilities to record fecal coliform concentrations in MORs from November through April. However, this study was interested only in the fecal coliform concentrations and loads during the recreational season designated by the Ohio EPA (May 1 through October 15). If known, the discharge design capacity of the WWTP was used in the model rather than the discharge recorded in the MORs. These discharge rates were chosen as part of the margin-of-safety requirements. (See "Margin of Safety" section for more information.)

\section{City of Springfield Combined Sewer Overflows (CSOs)}

Combined storm and sanitary sewers within the City of Springfield are another potential source of nitrate and fecal coliform to the Mad River Basin. This system is activated during storm events, when the capacity of the sewers is exceeded and untreated wastewater may overflow into streams. A total of 59 CSOs discharge within the City of Springfield (fig. 10) (Camp Dresser \& McKee, 1999). Most of the outfalls discharge to streams in the Buck Creek Subbasin (53 outfalls) (Camp Dresser \& McKee, 1998). A total of $340 \mathrm{Mgal}$ of untreated stormwater and sanitary wastewater was discharged into the Buck Creek and Mill Creek Basins in 2003. This amount does not include the WWTP system relief (pipe identification DC01), which discharges directly into the Mad River. This system relief discharges untreated stormwater at rates estimated to be slightly greater than the combined discharge of the CSOs discharging into the Buck Creek and Mill Creek Basins (Camp Dresser \& McKee, 1999). Because systemrelief point DC01 is known to contribute the largest single total suspended solids and biochemical oxygen demand pollutant load, it is also assumed to contribute significant bacteria loads (Camp Dresser \& McKee, 1999).

Daily loads of fecal coliform and nitrate from the 59 active CSOs within the City of Springfield were estimated for this study. These CSOs were grouped by their discharge location in relation to the subbasin defined by the HSPF model. Each group of CSOs was treated as one CSO point source within that subbasin. In all, six subbasins in the HSPF model include a point source representing CSO discharges. No measurements of nitrate or fecal coliform have been taken directly from these CSOs. The model used a fecal coliform count of $215,000 \mathrm{col} / 100 \mathrm{~mL}$ in CSO discharges, which is based upon the median fecal coliform concentration from 603 CSO discharges sampled throughout the Nation (U.S. Environmen- 
Table 8. Point-source dischargers included in the Hydrological Simulation Program-Fortran model of the Mad River Basin.

[Flows computed from U.S. Environmental Protection Agency's Permit Compliance System database and Ohio Environmental Protection Agency data; Mgal/d, million gallons per day; MHP, mobile home park; WWTP, wastewater-treatment plant; RM, river mile; na, not available]

\begin{tabular}{|c|c|c|c|c|}
\hline $\begin{array}{l}\text { Reference } \\
\text { number } \\
\text { (fig. 10) }\end{array}$ & Facility name & Receiving stream & $\begin{array}{c}\text { Median dis- } \\
\text { charge } \\
(1999-2004) \\
(\mathrm{Mgal} / \mathrm{d}) \\
\end{array}$ & $\begin{array}{l}\text { Design capacity } \\
\quad(\mathrm{Mgal} / \mathrm{d})\end{array}$ \\
\hline 1 & A \& R Sunset Terrace MHP & Moore Run & 0.02 & na \\
\hline 2 & Beaver Valley Resort & Beaver Creek & .009 & na \\
\hline 3 & Bridgewood MHP & Beaver Creek & .008 & na \\
\hline 4 & Brookside Village MHP & Sinking Creek & .03 & na \\
\hline 5 & Catawba WWTP & $\begin{array}{l}\text { Tributary to East Fork Buck } \\
\text { Creek }\end{array}$ & .23 & na \\
\hline 6 & Chateau Estates MHP & East Fork Donnels Creek & .06 & na \\
\hline 7 & $\begin{array}{l}\text { Clark County Southwest Regional } \\
\text { WWTP }\end{array}$ & Mad River (RM 13.33) & 1.2 & 2.0 \\
\hline 8 & Clark Industrial Park & Moore Run & .004 & na \\
\hline 9 & Clearview MHP & $\begin{array}{l}\text { Tributary to Mad River } \\
\text { (RM 24.98) }\end{array}$ & .01 & na \\
\hline 10 & Enon Heights MHP & $\begin{array}{l}\text { Tributary to Mad River } \\
\text { (RM 21.1) }\end{array}$ & .013 & na \\
\hline 11 & Fairborn WWTP & Mad River (RM 9.62) & 4.0 & 5.5 \\
\hline 12 & Graham South Elementary School & Chapman Creek & .002 & na \\
\hline 13 & Greenon High School & Tributary to Mud Run & .001 & na \\
\hline 14 & Harmony Estates MHP & Tributary to Beaver Creek & .05 & na \\
\hline 15 & Harvest Square MHP & Moore Run & .02 & na \\
\hline 16 & Hustead School & Tributary to Mud Run & .001 & na \\
\hline 17 & Kamp-a-Lott Campground & $\begin{array}{l}\text { Tributary to Mad River } \\
\text { (RM 61.41) }\end{array}$ & .025 & na \\
\hline 18 & Kirkmont Center & Sugar Creek & .04 & na \\
\hline 19 & Navistar & Tributary to Moore Run & .16 & na \\
\hline 20 & Northeastern High School & Sinking Creek & .02 & na \\
\hline 21 & Northwest Schools & East Fork Donnels Creek & .01 & na \\
\hline 22 & Rolling Hills MHP & Tributary to Moore Run & .05 & na \\
\hline 23 & Saint Paris WWTP & Tributary to Nettle Creek & .34 & na \\
\hline 24 & South Vienna WWTP & Beaver Creek & .06 & na \\
\hline 25 & Springfield Beckley Airport & Mill Creek & .04 & na \\
\hline 26 & Springfield WWTP & Mad River (RM 25.34) & 16.0 & 25.0 \\
\hline 27 & Tecumseh High School & Tributary to Jackson Creek & 0.01 & na \\
\hline 28 & Urbana School District & Dugan Run & .002 & na \\
\hline 29 & Urbana WWTP & Mad River (RM 39.15) & 1.9 & 3.0 \\
\hline 30 & Valley View MHP & Bogles Run & .015 & na \\
\hline 31 & West Liberty Salem School & Macochee Ditch & .004 & na \\
\hline 32 & West Liberty WWTP & $\begin{array}{l}\text { Tributary to Mad River } \\
\text { (RM 51.06) }\end{array}$ & .4 & .5 \\
\hline
\end{tabular}




\section{EXPLANATION}

- Combined-sewer overflow

- Point source and reference number

Water-quality calibration station and reference

$\frown$ Mad River

Tributary stream

S Mad River Basin

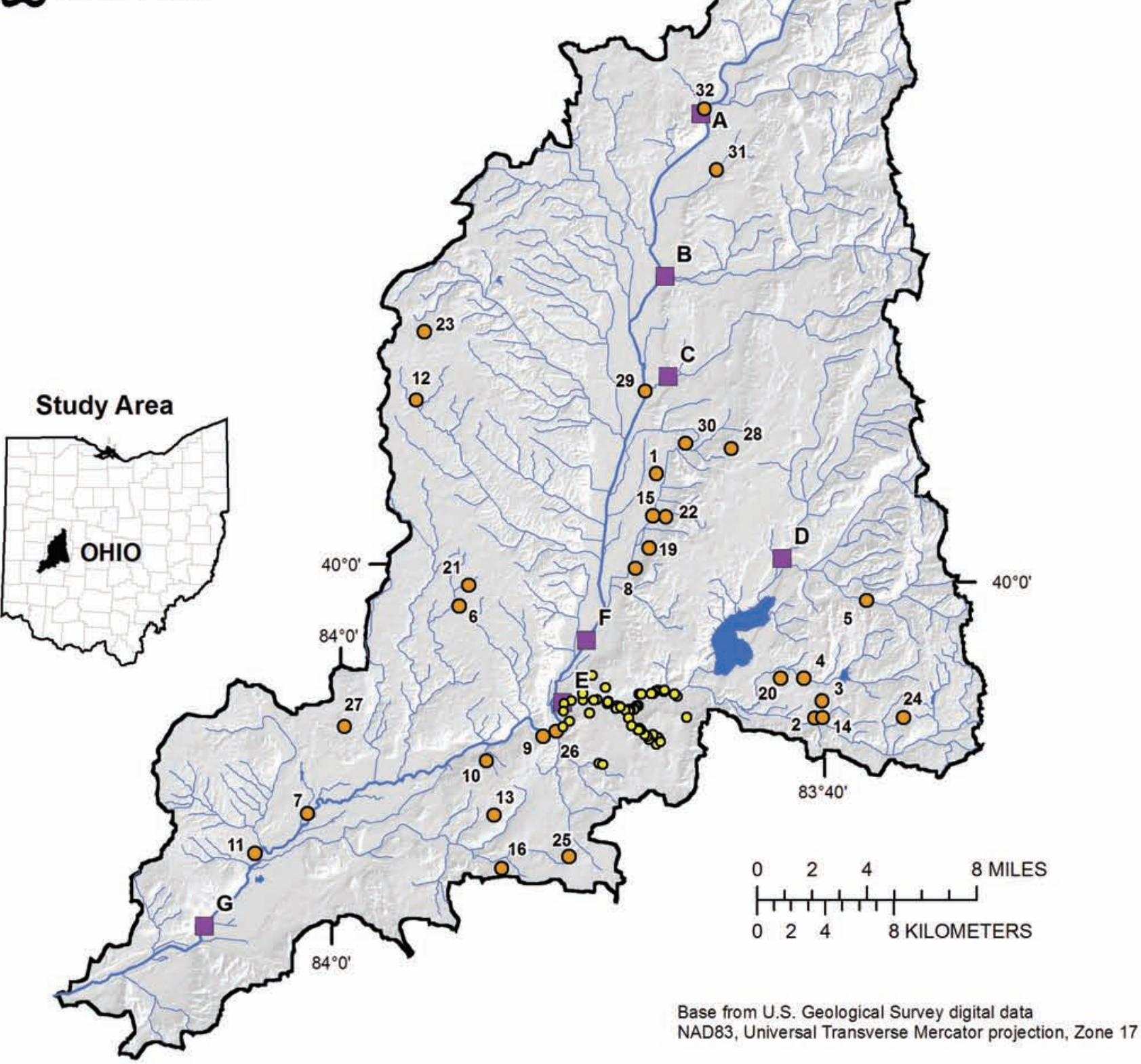

Figure 10. Locations of water-quality stations used for calibration of the water-quality model and locations of wastewatertreatment plants and combined-sewer overflows in the Mad River Basin. (Data from U.S. Environmental Protection Agency, 2003; Camp Dresser and McKee, 1997.) 
tal Protection Agency, 2004b). The nitrate concentration in the CSO discharge was estimated to be $1.8 \mathrm{mg} / \mathrm{L}$ on the basis of the median nitrate concentration from 13 CSO discharges sampled in Youngstown, Ohio (Stoeckel and Covert, 2002). The CSO discharge volumes also had to be estimated for the calibration period of the model (1999-2003). Camp Dresser $\&$ McKee (CDM) was contracted by the City of Springfield to develop a model to simulate the overflow volumes of the CSOs during storm events (Camp Dresser \& McKee, 1999). However, CDM was able to simulate discharge volumes only from 1988 through 1994. To estimate the CSO discharge volumes during rain events for the HSPF calibration period (1999-2003), a relation between precipitation and the CSO discharge had to be developed from the CDM model. The model equations of precipitation and streamflow in relation to CSO discharge volume were determined for each of the model subbasins with CSOs during 1988 through 1994 (table 9).

These equations were then used to determine CSO discharge volumes for the simulation period for each model subbasin on the basis of 1999-2003 precipitation data and streamflow data from the Mad River at Springfield.

\section{Cattle in Streams}

The Bacterial Indicator Tool (BIT) was used to estimate the direct contribution of fecal coliform from cattle in streams. A BIT assumption is that only beef cattle graze on pastures; therefore, only beef cattle have access to streams (U.S. Environmental Protection Agency, 2000b). Dairy cattle are assumed to be kept only in feedlots. These contributions are treated as individual point sources for each subbasin of the HSPF model. The number of cattle in streams was computed for each month by multiplying the number of beef cattle within each subbasin of the model by an assumed fraction of time that grazing cattle were in a stream. The number of beef cattle was estimated for each subbasin from the countylevel data provided by the National Agricultural Statistics Service (2004a). In the model, the beef cattle are assumed to be evenly distributed within the pastures. Subbasins within Logan County were the exception to this method. The number of beef cattle had been plotted on county property-ownership plat maps by the Logan County Soil and Water Conservation District; therefore, a more precise estimate was applied to subbasins within this county. Cattle in the study area spend less than 1 percent of their grazing time directly in a stream

Table 9. Equations relating precipitation and next-day daily mean streamflow to combined-sewer-overflow (CSO) discharge volume for each subbasin with a CSO.

\begin{tabular}{|c|c|c|c|}
\hline Subbasin & Model equation & p-value & $\begin{array}{c}\mathbf{r}^{2} \\
\text { value }\end{array}$ \\
\hline 19 & $\begin{array}{l}\text { Volume }=-0.22+\left(0.087 * \log _{10}(\text { streamflow })\right)+(0.26 * \text { precipitation })+ \\
\quad\left(0.027 * \text { precipitation }^{2}\right)\end{array}$ & $<0.0001$ & 0.15 \\
\hline 28 & $\begin{array}{l}\text { Volume }=-1.55+\left(0.59 * \log _{10}(\text { streamflow })\right)+(1.73 * \text { precipitation })+ \\
\qquad\left(0.21 * \text { precipitation }^{2}\right)\end{array}$ & $<0.0001$ & .14 \\
\hline 35 & Volume $=-3.33+\left(1.29 * \log _{10}(\right.$ streamflow $\left.)\right)+(4.23 *$ precipitation $)$ & $<0.0001$ & .26 \\
\hline 47 & $\begin{array}{l}\text { Volume }=-1.76+\left(0.67 * \log _{10}(\text { streamflow })\right)+(2.19 * \text { precipitation })+ \\
\quad\left(0.14 * \text { precipitation }^{2}\right)\end{array}$ & $<0.0001$ & .18 \\
\hline 48 & $\begin{array}{l}\text { Volume }=-0.064+\left(0.025 * \log _{10}(\text { streamflow })\right)+(0.056 * \text { precipitation })+ \\
\quad\left(0.018 * \text { precipitation }{ }^{2}\right)\end{array}$ & $<0.0001$ & .09 \\
\hline 49 & $\begin{array}{l}\text { Volume }=-5.46+\left(2.12 * \log _{10}(\text { streamflow })\right)+(8.63 * \text { precipitation }) \\
\quad-\left(1.14 * \text { precipitation }{ }^{2}\right)\end{array}$ & $<0.0001$ & .38 \\
\hline
\end{tabular}


(Jennifer Ganson, Ohio State University Agricultural Extension-Champaign County office, oral commun., 2005). Model calibration set the amount of time an individual animal was in a stream at 0.05 percent of the day (less than 1 minute). A percentage much smaller than 1 was selected for the model because of the BIT assumption is that all beef cattle grazing have access to streams. Many properties in the Mad River Basin are fenced in order to limit access to streams, although the proportions of fenced and unfenced properties are unknown. A further HSPF model assumption is that cattle did not graze on the pastures during December through March and grazed only half of the time during April and November.

The fecal coliform load from cattle in streams was computed in the BIT by multiplying the number of beef cattle in the subbasin by the percentage of the day that the cattle are in the streams and the daily production rate of fecal coliform per animal (U.S. Environmental Protection Agency, 2000b). The BIT production rate of $1.04 \times 10^{11}$ fecal coliform colonies per animal per day is based on a standard established by the American Society of Agricultural Engineers (American Society of Agricultural Engineers, 1998).

For the HSPF model, it is assumed that one beef cattle produces $124 \mathrm{lb}$ of total nitrogen per year from solids and 120 $\mathrm{lb}$ of total nitrogen per year from urine on the basis of a study by The Ohio State University (Ohio State University Extension, 1992). Although most nitrogen in manure is in the form of ammonium and organic nitrogen, these nitrogen species are eventually converted to nitrate. For this model, nitrogen from cattle waste was assumed to be nitrate. The nitrate load from cattle in streams was computed by multiplying the number of beef cattle in streams (same number computed in the BIT) by the daily production rate of nitrate per animal.

\section{Failed Septic Systems}

The Ohio State University Extension determined that approximately 76 percent of the soils in the Mad River Basin are suitable for septic systems. However, when comparing treatment systems, their study found that less than 5 percent of the soils were suitable for the traditional leach-line treatment systems, approximately 45 percent of the soils were suitable only for mound treatment systems, and approximately 30 percent of the soils were suitable for onsite treatment with irrigation (Mancl and Slater, 2002). Suitable soils are necessary to properly treat wastewater from a septic system. Unsaturated zones should be deep enough to remove pollutants from wastewater before the wastewater enters the water table. Other limiting conditions include soils that are insufficiently permeable, such as some soils derived from glacial till. Glacial till is present in many areas of the Mad River Basin (fig. 2).

Data obtained from the health departments for Clark, Champaign, and Logan Counties indicated that approximately 28,000 septic systems are in use within the Mad River Basin. Although the approximate number of septic systems was available, none of the counties had information regarding the locations of the septic systems. However, the number of households within each township was available from the Ohio State University Extension Data Center (2004). In addition, 250 households within the City of Springfield (about 1 percent of the total) are known to be on a septic system (Robin Berry, Clark County Health Dept., oral commun., 2005). The assumption was made that all households in a rural township were on a septic system but that only 1 percent of the households in the urban areas were on a septic system. The septic systems were assumed to be distributed evenly within the townships and cities. From this information, the number of septic systems was estimated for each subbasin of the model.

The BIT was used to compute the contribution of fecal coliform to streams from failed septic systems. These contributions are treated as individual point sources for each subbasin of the HSPF model. Concentration and overflow-rate assumptions for the BIT simulation of failed septic systems are $10,000 \mathrm{col} / 100 \mathrm{ml}$ and 70 gal per person per day, respectively (U. S. Environmental Protection Agency, 2000b). On the basis of estimates of the number of people served by septic systems and the number of septic systems for the Mad River Basin, the BIT determined that an average of 2.76 people are served per septic system in the Mad River Basin. A 90-percent failure rate of septic systems was used in the model for the Mad River Basin on account of the small percentage of suitable soils and the prevalence of traditional leach-line systems in the study area. The BIT was able to compute the flow from failed septic systems and the fecal coliform load for each subbasin of the HSPF model.

The flow rates computed from the BIT and a nitrate concentration of $1.1 \mathrm{mg} / \mathrm{L}$ were used to determine the nitrate loads from the failed septic systems for each reach in the HSPF model. The selected nitrate concentration is based on the average nitrate concentration from septic-system drainage fields in Medina County, Ohio (Shindel and others, 2005, p. 248). Nitrogen in conventional septic tanks is usually in the form of ammonium (75 percent) and organic nitrogen ( 25 percent). As the effluent leaves the septic tank and moves through the soils, ammonium nitrogen is converted to nitrite and then to nitrate. Ammonium nitrogen can also be removed by adsorption, volatilization, or plant uptake (Kristiansen, 1981), although this model does not consider the effects of plant uptake of nitrogen in the simulation. The model assumption is that all nitrogen from the septic tank that reaches the streams has converted to nitrate.

\section{Commercial-Fertilizer and Manure Applications}

Soybeans, corn, and, to a lesser extent, winter wheat make up the majority of crops planted in the Mad River Basin. Corn and soybeans are typically planted from April through May, whereas winter wheat is typically planted in October. Approximately 50 percent of cropland in the Mad River Basin is used for soybean production and 40 percent is used for corn production (National Agricultural Statistics Service, 2004b). Most of the commercial nitrogen fertilizer used in the study area, however, is for corn. In Ohio, nitrogen fertilizer is 
applied to nearly 100 percent of the corn acreage but only 21 percent of the soybean acreage (Ohio Department of Agriculture, 2000). Fertilizers generally are applied in spring during corn planting. Nitrogen fertilizer is generally reapplied to corn fields 6 to 10 weeks after planting (table 10). In western Ohio, the application rate of nitrogen is in the range of 150 to $200 \mathrm{lb} / \mathrm{acre}$ for corn. For wheat, fertilizers are applied in late summer through early autumn. If not enough nitrogen is available from the previous soybean crop, then starter nitrogen is applied to the wheat fields at a rate less than $20 \mathrm{lb} /$ acre (Ohio State University Extension, 2001).

Manure is applied not only to supply nutrients but also to improve the water-holding capacity of soil, improve aeration of soil, and promote beneficial microorganisms (Ohio State University Extension, 1992). Unfortunately, manure is not only a source of nitrogen but also a source of fecal coliform and other types of bacteria. Manure is generally applied to corn fields in March and April and to winter wheat fields from August through November (table 11). An estimated 17 percent of the corn acreage, 8 percent of the soybean acreage, and 5 percent of the wheat acreage in Ohio receive applications of manure (Ohio State University Extension, 1995). Contributions to the storage limits and accumulation rates of fecal coliform from manure applications are determined by the BIT. The fecal coliform contributions from manure applications are based on the amount of waste produced by the animals in the subbasin, the fraction of manure applied each month, the fraction of manure incorporated in the soil, and the fraction available for runoff.

This study did not use the commercial fertilizer and manure application information directly in the model. However, this information was used to assign accumulation rates and storage capacities to the agricultural lands during application periods.

Table 10. Fraction of commercial fertilizer applied by month, by crop type.

[Source: Mike Haubner, Ohio State University Extension, Clark Co., written commun., 2005]

\begin{tabular}{lcccccc}
\hline \multicolumn{1}{c}{ Crop type } & March & April & May & June & October & November \\
\hline Corn and soybeans & 0.20 & 0.30 & 0.30 & 0.15 & -- & 0.05 \\
Winter wheat & 0.75 & -- & -- & -- & 0.25 & -- \\
\hline
\end{tabular}

Table 11. Fraction of manure applied by month, by crop type.

[Source: Mike Haubner, Ohio State University Extension, Clark Co., written commun., 2005]

\begin{tabular}{lcccccc}
\hline \multicolumn{1}{c}{ Crop type } & March & April & August & September & October & November \\
\hline Corn and soybeans & 0.5 & 0.5 & -- & -- & -- & -- \\
Winter wheat & -- & -- & 0.25 & 0.25 & 0.25 & 0.25 \\
\hline
\end{tabular}

Table 12. Wet and dry atmospheric deposition of nitrate, by season, at three National Atmospheric Deposition Program/National Trends Network stations in Ohio, 1999-2003.

[National Atmospheric Deposition Program (2005); na, not available]

\begin{tabular}{|c|c|c|c|c|c|c|}
\hline \multirow{3}{*}{ 1999-2003 } & \multicolumn{6}{|c|}{ Wet and dry deposition, in pounds per acre, by station } \\
\hline & \multicolumn{2}{|c|}{$\begin{array}{c}\text { OH17 } \\
\text { Delaware }\end{array}$} & \multicolumn{2}{|c|}{$\begin{array}{c}\text { 0H54 } \\
\text { Deer Creek }\end{array}$} & \multicolumn{2}{|c|}{$\begin{array}{c}\text { OH09 } \\
\text { Oxford }\end{array}$} \\
\hline & Wet & Dry & Wet & Dry & Wet & Dry \\
\hline Annual mean & 14.1 & na & 12.7 & 0.57 & 12.7 & 0.58 \\
\hline Winter mean & 2.5 & na & 2.2 & .24 & 2.3 & .23 \\
\hline Spring mean & 5.0 & na & 4.5 & .13 & 3.8 & .13 \\
\hline Summer mean & 4.4 & na & 4.0 & .05 & 4.2 & .06 \\
\hline Fall mean & 2.2 & na & 2.0 & .16 & 2.3 & .16 \\
\hline
\end{tabular}




\section{Atmospheric Deposition}

Nitrogen entering the hydrologic system by atmospheric deposition is primarily derived from burning of coal for electricity generation (Debrewer and others, 2000). The source of the airborne nitrogen may be hundreds of miles outside the study area (U.S. Environmental Protection Agency, 2004a). "Wet deposition" refers to contaminants (in this case, nitrate) that are dissolved in or adsorbed onto particles in precipitation, whereas "dry deposition" refers to contaminants that are adsorbed onto dust particles. Nitrate concentrations in wet deposition (rain or snow) have been monitored since 1978 by the National Atmospheric Deposition Program/National Trends Network (NADP/NTN) (2005), which includes six stations in Ohio. No NADP/NTN stations are in the Mad River Basin; however, three stations (City of Oxford in northwestern Butler County, Deer Creek State Park in Pickaway County, and City of Delaware in Delaware County) are in the surrounding area. Annual mean wet deposition of nitrate ranged from 12.7 to $14.1 \mathrm{lb} /$ acre at the three stations for calendar years 1999 through 2003. Deposition was greatest in the spring and summer and least in the fall and winter (table 12, p. 29).

Dry deposition in the United States has been monitored by the Clean Air Status and Trends Network (CASTNET) since 1987 (U.S. Environmental Protection Agency, 2004a). CASTNET measures nitric acid $\left(\mathrm{HNO}_{3}\right)$ vapor and particulate nitrate nitrogen fluxes in dry deposition. The Mad River Basin lies between two CASTNET monitoring stations, one in northwestern Butler County (Oxford station) and the other in Pickaway County (Deer Creek station). Of the average nitrogen deposition at these two stations from 1999 through 2003, approximately 35 percent was wet deposition of nitrate, whereas less than 2 percent was dry deposition of nitrate (U.S. Environmental Protection Agency, 2004a).

Atmospheric deposition of nitrate was included in the HSPF model as dry deposition in the form of a flux (mass per area per time) and as wet deposition in the form of a concentration in rainfall. The monthly dry and wet deposition of nitrate was computed and entered into the model as a time series from the WDM file. The HSPF model combines the rainfall concentration with the precipitation time series to compute a monthly nitrate flux.

\section{Observed Water-Quality Data}

Water-quality data used to calibrate the HSPF model for fecal coliform and nitrate concentrations were available from sampling activities of the Ohio EPA, the USGS, the Upper Mad River Steering Committee, and the MCD at seven sites in the basin (table 13; fig. 10). Mad River at St. Paris Pike near Eagle City, Ohio, had the largest water-quality database, which permitted calibration of the model from January 1, 1999, through September 30, 2003. However, data from only 166 nitrate and 28 fecal coliform samples had been collected at this site over the 5-year period. Other sites had even less water-quality data and could be calibrated only for 2003 (table
13 and figure 10). Calibration of the model was limited by availability of water-quality data. This, unfortunately, leads to a greater uncertainty in the results produced by the model.

The City of Springfield collected stream samples for fecal coliform analysis from sites within Buck Creek Subbasin and on the Mad River immediately upstream from the Buck Creek confluence and immediately downstream from the Mill Creek confluence during six rain events in summer 2002. CSOs did not contribute to the Mad River upstream site, whereas all of the CSOs were contributing to the Mad River downstream site. The fecal coliform concentrations from the upstream site ranged from 320 to $4,700 \mathrm{col} / 100 \mathrm{~mL}$, with a mean of $1,500 \mathrm{col} / 100 \mathrm{~mL}$. The fecal coliform concentrations from the downstream site ranged from 130 to $380,000 \mathrm{col} / 100 \mathrm{~mL}$, with a mean of $100,000 \mathrm{col} / 100 \mathrm{~mL}$. Some samples collected from Buck Creek had fecal coliform concentrations that were greater than $1,000,000 \mathrm{col} / 100 \mathrm{~mL}$.

The USGS and MCD also measured nitrate in samples collected from selected shallow water wells (depths of $50 \mathrm{ft}$ or less) in the Mad River Basin. The USGS collected samples in 1999 from 5 wells and the MCD collected samples in 2003 from 13 wells. The nitrate concentrations from the USGSsampled wells ranged from less than 0.05 to $15 \mathrm{mg} / \mathrm{L}$, whereas the nitrate concentrations from the MCD-sampled wells ranged from less than 0.02 to $17.8 \mathrm{mg} / \mathrm{L}$. The nitrate concentrations in these samples were used to determine an acceptable range of nitrate concentrations that could be used for the ground-water contributions from the model subsurface zones.

\section{Water-Quality Calibration}

The HSPF model was calibrated by comparing the modeled concentrations to observed concentrations of fecal coliform and nitrate. Initial model water-quality parameters were assigned as a function of meteorologic zone (described earlier in report; fig. 7) and the land-cover types in the study area. Parameters that could be adjusted in this model included the interflow and ground-water concentrations of fecal coliform and nitrate, monthly accumulation rates of fecal coliform and nitrate on the land surface, and the monthly maximum storage of fecal coliform and nitrate on the land surface. The HSPFParm program (Donigian and others, 2000) was used to identify reasonable initial values for many of the waterquality parameters needed for the fecal coliform and nitrate model. HSPFParm is a model-parameter database that contains parameter values used in calibrated models developed elsewhere. The HSPFParm program entries that were most similar to conditions in the Mad River were from models for agricultural watersheds with corn and soybean crops.

The subbasin in which C.J. Brown Reservoir is located required special calibration considerations because the reservoir acts as a sink for fecal coliform and nitrate. The observed fecal coliform and nitrate concentrations were significantly lower in the stream immediately downstream from the reservoir than immediately upstream. The low fecal coliform counts are likely due to die-off and predation during 
Table 13. Water-quality data from surface-water sites used to calibrate the model of the Mad River Basin.

[OEPA, Ohio Environmental Protection Agency; UMSC, Upper Mad River Steering Committee; USGS, U. S. Geological Survey; MCD, Miami Conservancy District; S.R., State Route]

\begin{tabular}{|c|c|c|c|c|c|}
\hline $\begin{array}{c}\text { Reference } \\
\text { letter } \\
\text { (fig. 10) } \\
\end{array}$ & Sample site & $\begin{array}{c}\text { Source of } \\
\text { data }\end{array}$ & $\begin{array}{l}\text { Number of nitrate } \\
\text { samples collected }\end{array}$ & $\begin{array}{l}\text { Number of fecal coli- } \\
\text { form samples collected }\end{array}$ & $\begin{array}{l}\text { Year(s) of sampling activity } \\
\text { used for model calibration }\end{array}$ \\
\hline \multirow[b]{2}{*}{ A } & Mad River at Pimtown & OEPA & 6 & 5 & 2003 \\
\hline & $\begin{array}{l}\text { Road near West } \\
\text { Liberty }\end{array}$ & UMSC & 12 & 5 & 2003 \\
\hline \multirow{2}{*}{ B } & & OEPA & 6 & 5 & 2003 \\
\hline & Kings Creek at S.R. 290 & UMSC & 12 & 5 & 2003 \\
\hline \multirow{2}{*}{$\mathrm{C}$} & \multirow{2}{*}{$\begin{array}{l}\text { Dugan Run at Muzzy } \\
\text { Road }\end{array}$} & OEPA & 6 & 4 & 2003 \\
\hline & & UMSC & 12 & 5 & 2003 \\
\hline $\mathrm{D}$ & Buck Creek at S.R. 4 & OEPA & 6 & 0 & 2003 \\
\hline $\mathrm{E}$ & $\begin{array}{l}\text { Buck Creek at Synder } \\
\text { Park }\end{array}$ & OEPA & 6 & 0 & 2003 \\
\hline \multirow{2}{*}{$\mathrm{F}$} & \multirow{2}{*}{$\begin{array}{l}\text { Mad River at St. Paris } \\
\text { Pike near Eagle City }\end{array}$} & OEPA & 60 & 28 & 1999-2003 \\
\hline & & USGS & 106 & 0 & 1999-2003 \\
\hline \multirow{2}{*}{ G } & \multirow{2}{*}{$\begin{array}{l}\text { Mad River at Huffman } \\
\text { Dam }\end{array}$} & OEPA & 6 & 5 & 2003 \\
\hline & & MCD & 137 & 0 & 2003 \\
\hline
\end{tabular}

the retention time in the reservoir, whereas the low nitrate concentrations are likely due to plant uptake and denitrification. In order to accurately simulate fecal coliform loss in the reservoir, the decay rate for the subbasin that includes C.J. Brown Reservoir had to be set at a high level (10,000 per day). A biodegradation rate was set in the HSPF model to reproduce the decrease in nitrate concentrations below the reservoir (Paul Hummel, Aqua Terra Consultants, oral commun., 2005).

Fecal coliform concentrations initially assigned to monthly interflow (MON-IFLW-CONC) were adjusted during calibration. For the calibrated model, fecal coliform concentrations in interflow water ranged from $10 \mathrm{col} / 100 \mathrm{~mL}$ in forests and water to $60,000 \mathrm{col} / 100 \mathrm{~mL}$ in some agricultural lands. In this model, fecal coliforms were assumed to be absent in ground water. Sand and gravel aquifer systems, such as those found in the study area, tend to act as a filtering mechanism that prevents pathogens, such as fecal coliform, from reaching the ground water. Although ground-water samples collected in the study area were not analyzed for fecal coliform, groundwater samples have been analyzed for $E$. coli. This particular bacteria species has rarely been detected in the samples (Richard Bendula, Ohio Environmental Protection Agency, oral commun., 2006).

The BIT was also used to estimate the monthly accumulation rate of fecal coliform on the land surface and the accumulation limit of fecal coliform should no washoff occur
(U.S. Environmental Protection Agency, 2000b). User-defined values supplied to the BIT for each meteorologic zone were land-cover distribution, number of agricultural animals and their monthly grazing patterns, wildlife densities, and the patterns of monthly manure applications to cropland and pasture. Agricultural animals included in the BIT were beef cattle, dairy cattle, swine, poultry, horses, and sheep. Assumptions in the BIT are that manure from swine and poultry is applied only to agricultural lands and that manure from horses and sheep is applied only to pastures. Cattle are assumed to contribute manure to both land covers. Wildlife animals included in the BIT were deer, geese, ducks, beaver, and raccoons. The wildlife densities are computed only for forest, pasture, and agricultural lands and are considered constant for each of these land covers. The fraction of each manure type incorporated into the soils ranged from 0.75 (for cattle) to 0.96 (for poultry). These were the default settings supplied by the BIT. Animal waste production rates and fecal coliform content values used in the model were from American Society of Agricultural Engineers (1998). Model calibration resulted in a 20-percent increase to the accumulation rate initially estimated with the BIT for meteorologic zone 4 and a 40-percent decrease to the storage limit computed by the BIT for meteorologic zones 2, 4, and 7 (fig. 7). Values for these meteorologic zones were adjusted to better match the simulated fecal coliform concentrations to the observed concentrations. Values of the principal 
parameters used to calibrate the fecal coliform model are listed in Appendix 3.

Nitrate concentrations in the interflow water and ground water within the Mad River Basin were initially assigned to each land-cover type for each meteorologic zone on the basis of available ground-water data and data from the HSPFParm database. The lowest interflow and ground-water nitrate concentrations were initially set at $0.5 \mathrm{mg} / \mathrm{L}$ for forest and water areas, whereas the highest nitrate concentrations were initially set at $5 \mathrm{mg} / \mathrm{L}$ for agricultural lands. Nitrate concentrations were eventually adjusted for the monthly interflow (MONIFLW-CONC) and ground-water (MON-GRND-CONC) parameters for most agricultural and pasture lands during model calibration. In the calibrated model, nitrate concentrations in ground water ranged from $0.3 \mathrm{mg} / \mathrm{L}$ in forest and waterbodies to $9 \mathrm{mg} / \mathrm{L}$ in agricultural areas within the Kings Creek meteorologic zone (no. 7), and nitrate concentrations in the interflow ranged from $0.25 \mathrm{mg} / \mathrm{L}$ in forest and waterbodies to $15 \mathrm{mg} / \mathrm{L}$ in agricultural areas within the Kings Creek meteorologic zone. High nitrate concentrations have been observed in Kings Creek and are thought to result from the link between the agricultural practices and the shallow aquifer in this meteorologic zone (Ohio Environmental Protection Agency, 2005a).

No program similar to the BIT is available to estimate the accumulation rate or the storage limit of nitrate on the land surface for the various land covers in the individual zones. The HSPFParm database was again used to estimate some initial values on the basis of previous HSPF modeling of nitrate from other watersheds within the corn-soybean region of the Nation (Donigian and others, 2000). Information regarding the application periods and application rates of commercial fertilizer and manure was useful for determining the range of these parameter values to use in the HSPF model and for determining in which months to increase or decrease these values. Months when fertilizer and manure applications are common were typically assigned higher accumulation rates and accumulation-limit values than months when applications are uncommon. Values of the principal parameters used to calibrate the nitrate model are listed in Appendix 4.

Daily mean concentrations of fecal coliform and nitrate simulated by the HSPF model are shown in figures 11 and 12 , along with simulated daily mean streamflow. Data shown in figures 11 and 12 are from the Mad River at St. Paris Pike and the Mad River at Huffman Dam, respectively. These sites had the largest number of observed values available for the calibration period. Great fluctuations in fecal coliform counts are seen in the observed and simulated values. Of the 27 fecal coliform values observed at the St. Paris Pike site for the calibration period, the highest count was $29,000 \mathrm{col} / 100$ $\mathrm{mL}$, whereas the lowest count observed was $10 \mathrm{col} / 100 \mathrm{~mL}$. With only five observed values at the Huffman Dam site, the fecal coliform count ranged from 140 to $24,000 \mathrm{col} / 100 \mathrm{~mL}$. Samples collected at Mad River at St. Paris Pike show little difference in nitrate concentrations from season to season, mainly because of the high contribution of base flow from ground water throughout the year. This provides a constant supply of nitrate to the streams. Samples collected by the Miami Conservancy District indicate that nitrate concentrations are lower during high-flow events at the Huffman Dam site than during normal flow conditions. This pattern suggests that nitrate concentration from runoff is higher than the nitrate concentration in the base flow and shows the effect of dilution on storm-water samples. This pattern was not observed in the nitrate concentrations at Mad River at St. Paris Pike, which is in an agriculture-dominated watershed and not affected by the CSO discharges originating from Springfield.

Simulated nitrate and fecal coliform values from the calibrated model were compared to observed values from seven sites within the study area (table 14). For this comparison, simulated mean nitrate or geometric mean fecal coliform concentrations were computed only for days with observed values. However, the simulated values are daily mean values, whereas the observed values are instantaneous. This distinction is especially important to remember when comparing the fecal coliform concentrations. Fecal coliform concentrations in a stream can change by orders of magnitude within a day if a runoff event has occurred. For fecal coliform, the ratios of geometric mean values of simulated concentrations to observed concentrations ranged from 0.15 to 1.18 . For nitrate, the ratios of mean values of simulated concentration to observed concentration ranged 0.85 to 1.17 . These results, especially for fecal coliform, reflect the uncertainty in the model output due to the scarcity of data available for model calibration. Values of the principal parameters used to calibrate the model for simulation of fecal coliform and nitrate concentrations are listed in Appendixes 3 and 4, respectively.

\section{Sensitivity Analysis}

A sensitivity analysis was done for the water-quality model. As noted previously, a sensitivity analysis indicates the response of a model to modifications of input values. The principal water-quality parameters used for model calibration were selected for sensitivity analysis. For most parameters, values were changed by 50 and 200 percent of their calibrated values (table 15). The model run was terminated before completion, however, when the monthly accumulation rates (MON-ACCUM) of fecal coliform were doubled and when the monthly limiting storage (MON-SQOLIM) of fecal coliform was halved. In these cases, smaller percentage changes in parameters were used (table 15). Changes in monthly accumulation rates and interflow concentrations (MON-IFLW-CONC) had little effect on the fecal coliform loads. Changes in the decay rates (FSTDEC), however, had a major effect on the fecal coliform loads (table 15); this is likely because of the minor contribution that nonpoint sources have to the fecal coliform loads. Changes to monthly ground-water concentrations (MON-GRND-CONC) of nitrate had a large effect on simulated nitrate loads, whereas changes to the monthly accumulation rates had the smallest effect (table 15). 

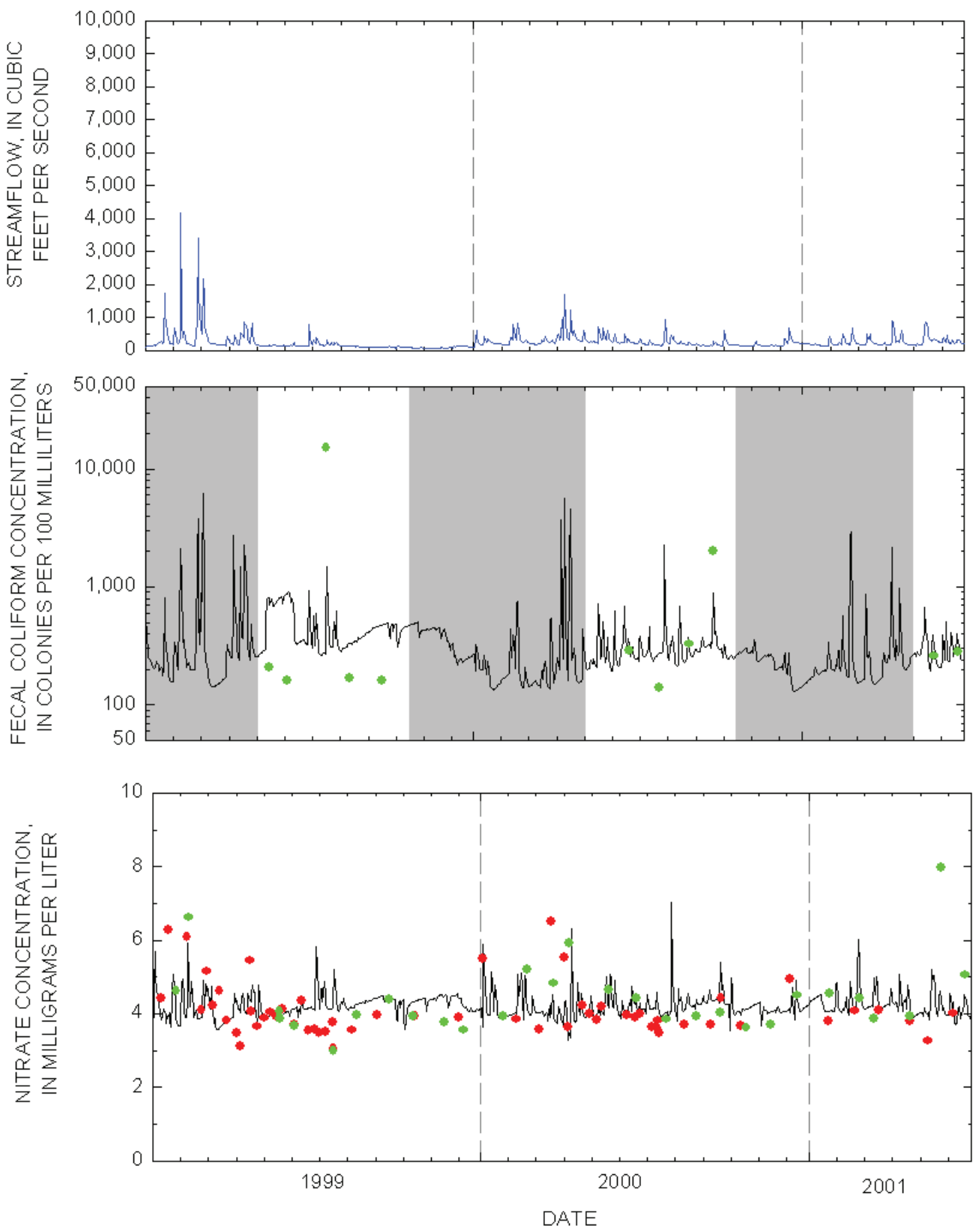

\section{EXPLANATION}

Non-recreation season (fecal coliform)

Samples collected by Ohio Environmental Protection Agency

Samples collected by U.S. Geological Survey

Figure 11a. Simulated daily mean streamflow, simulated daily mean concentrations of nitrate and fecal coliform, and observed instantaneous concentrations, Mad River at St. Paris Pike (03267900), January 1, 1999, through June 30, 2001. 

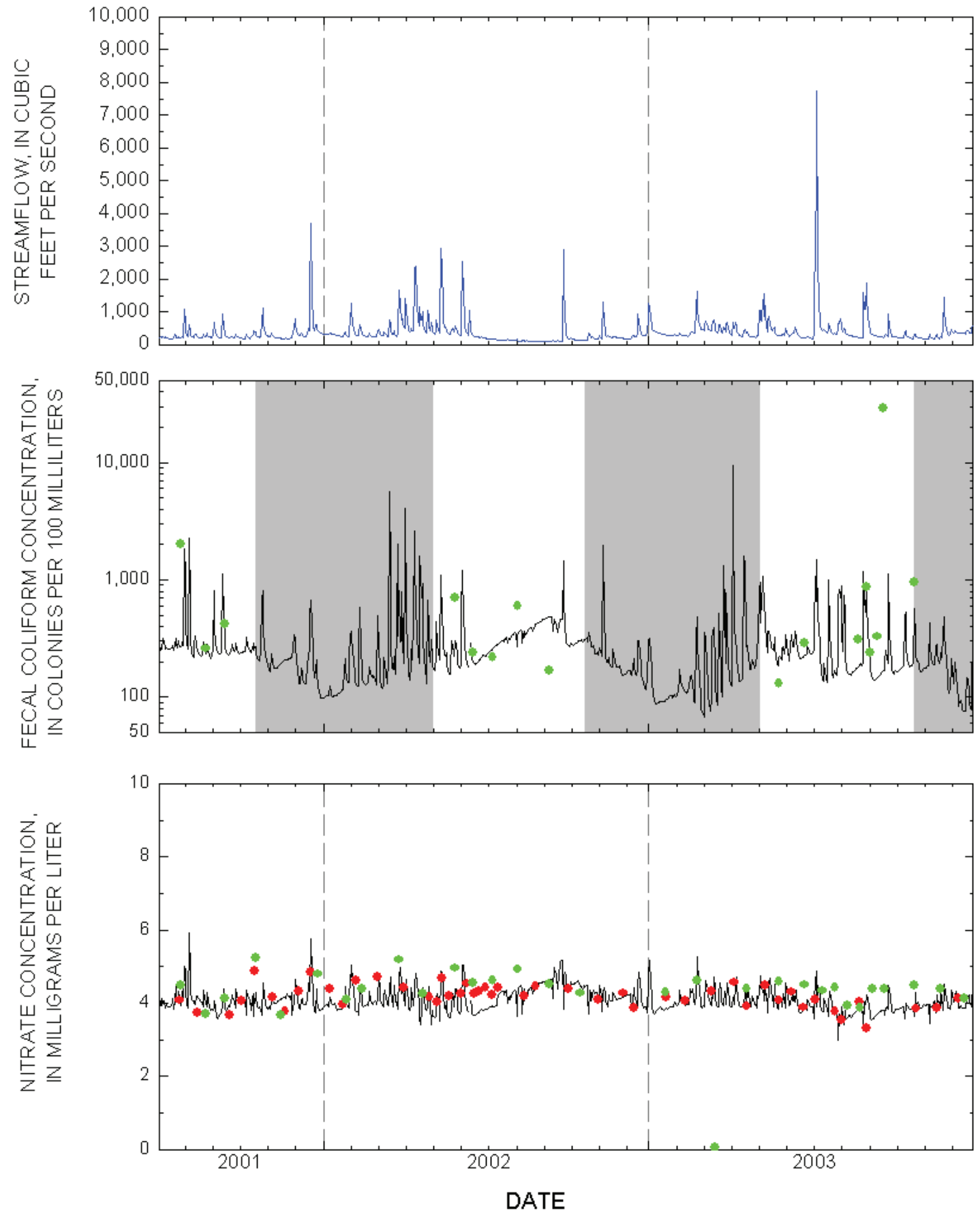

EXPLANATION

Nonrecreation season (fecal coliform)

- Samples collected by Ohio Environmental Protection Agency

- Samples collected byU.S. Geological Survey

Figure 11b. Simulated daily mean streamflow, simulated daily mean concentrations of nitrate and fecal coliform, and observed instantaneous concentrations, Mad River at St. Paris Pike (03267900), July 1, 2001, through December 31, 2003. 

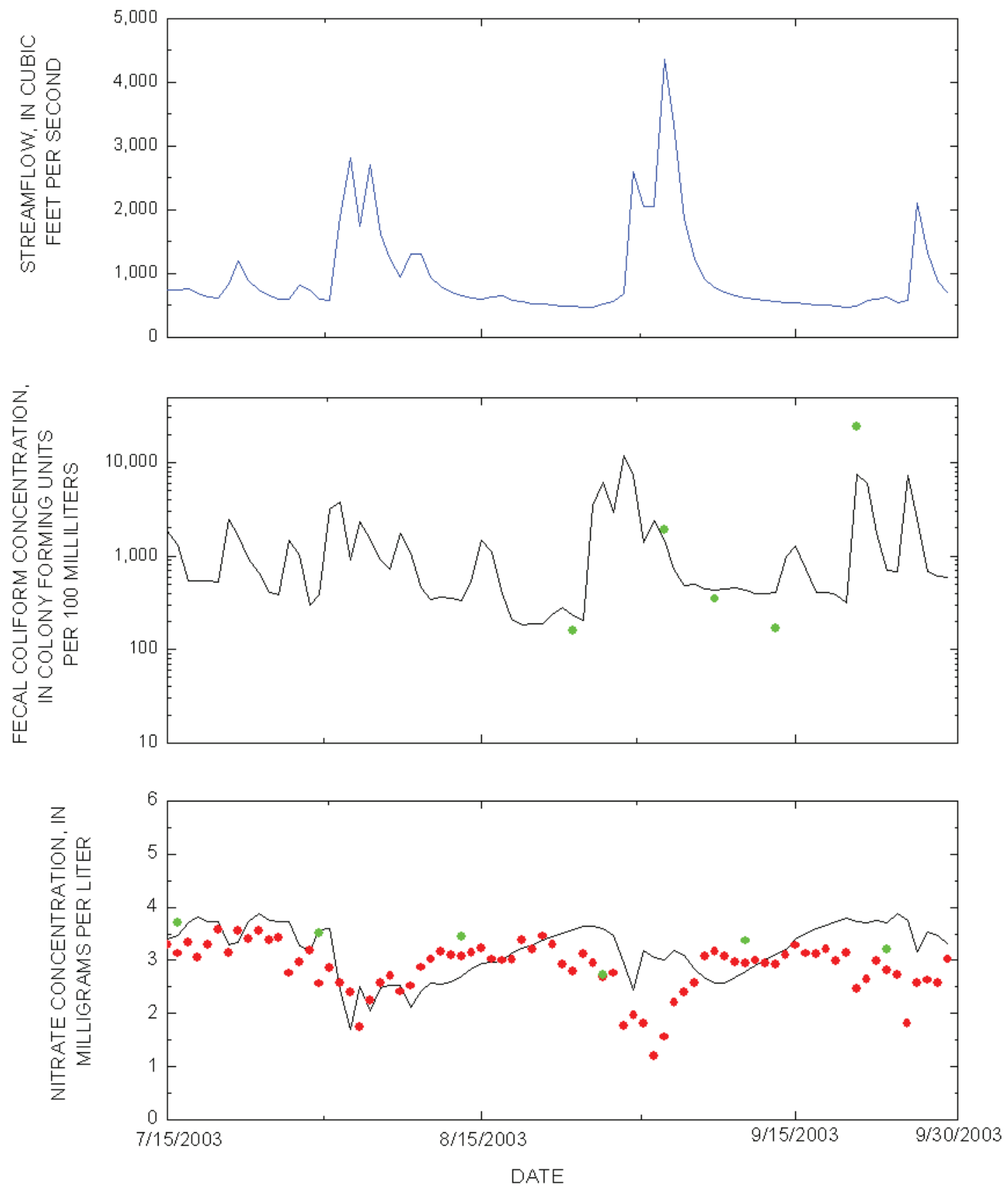

EXPLANATION

- Samples collected by Ohio Environmental Protection Agency

- Samples collected by Miami Conservancy District

Figure 12. Simulated daily mean streamflow, simulated daily mean concentrations of nitrate and fecal coliform, and observed instantaneous concentrations, Mad River at Huffman Dam (03270000), July 15 through September 30, 2003. 
Table 14. Comparison of observed and simulated nitrate and fecal coliform concentrations at sites in the Mad River Basin, 1999-2003.

[USGS, U.S. Geological Survey; OEPA, Ohio Environmental Protection Agency; UMSC, Upper Mad River Steering Committee; MCD, Miami Conservancy District; S.R., State Route; Ratio is the simulated concentration divided by the observed concentration]

\begin{tabular}{|c|c|c|c|c|}
\hline \multirow[b]{2}{*}{ Site } & \multicolumn{3}{|c|}{ Mean nitrate concentration, in milligrams per liter } & \multirow[b]{2}{*}{ Sample size } \\
\hline & $\begin{array}{l}\text { Observed (instanta- } \\
\text { neous) }\end{array}$ & $\begin{array}{c}\text { Simulated } \\
\text { (daily mean) }\end{array}$ & Ratio & \\
\hline Mad River at St. Paris & 4.12 - USGS & 4.13 & 1.00 & 106 \\
\hline Pike & 4.35 - OEPA & 4.30 & 0.99 & 60 \\
\hline Mad River at Pimtown & 3.43 - OEPA & 3.24 & .94 & 6 \\
\hline Road & $3.52-$ UMSC & 3.58 & 1.01 & 12 \\
\hline Kings Creek at S.R. 29 & $\begin{array}{l}7.15 \text { - OEPA } \\
7.36 \text { - UMSC }\end{array}$ & $\begin{array}{l}7.10 \\
7.60\end{array}$ & $\begin{array}{r}.99 \\
1.03\end{array}$ & $\begin{array}{r}6 \\
12\end{array}$ \\
\hline Buck Creek at S.R. 4 & 7.97 - OЕРА & 8.35 & 1.05 & 6 \\
\hline $\begin{array}{l}\text { Buck Creek at Snyder } \\
\text { Park }\end{array}$ & 1.75 - OEPA & 1.48 & .85 & 6 \\
\hline Dugan Run at Muzzy & 6.01 - OEPA & 5.95 & 0.98 & 6 \\
\hline Road & $5.97-$ UMSC & 6.15 & 1.03 & 12 \\
\hline Mad R. at Huffman & $3.00-\mathrm{MCD}$ & 3.49 & 1.16 & 137 \\
\hline Dam & 3.33 - OEPA & 3.31 & .99 & 6 \\
\hline \multicolumn{5}{|c|}{ Geometric mean fecal coliform concentration, in colonies per 100 milliliters } \\
\hline Site & $\begin{array}{c}\text { Observed } \\
\text { (instantaneous) }\end{array}$ & $\begin{array}{c}\text { Simulated } \\
\text { (daily mean) }\end{array}$ & Ratio & Sample size \\
\hline $\begin{array}{l}\text { Mad River at St. Paris } \\
\text { Pike }\end{array}$ & 365 - OEPA & 330 & 0.90 & 28 \\
\hline Mad River at Pimtown & 235 - UMSC & 220 & .94 & 5 \\
\hline Road & 961 - OEPA & 220 & .23 & 5 \\
\hline Kings Creek at S.R. 29 & 137 - UMSC & 180 & 1.17 & 5 \\
\hline $\begin{array}{l}\text { Buck Creek at Snyder } \\
\text { Park }\end{array}$ & 2,350- OEPA & 1,600 & 0.68 & 5 \\
\hline Dugan Run at Muzzy & 1,860 - OEPA & 280 & .15 & 4 \\
\hline Road & $206-$ UMSC & 245 & 1.18 & 5 \\
\hline $\begin{array}{l}\text { Mad R. at Huffman } \\
\text { Dam }\end{array}$ & 824 - OEPA & 810 & 0.98 & 5 \\
\hline
\end{tabular}

\section{Simulation Results}

The calibrated model was used to simulate loads and concentrations of fecal coliform and nitrate from sources within the basin. The simulated daily mean concentrations were compared to the target concentrations to identify the current water-quality conditions and to determine the percentage reduction in input loads needed to achieve the target concentrations. A load-reduction scenario was then modeled, and the results were assessed to determine whether target concentrations could be achieved. 
Table 15. Sensitivity analyses of modeled water-quality characteristics to variations in selected water-quality model parameters for the mouth of the Mad River (hydrologic unit 05080001-190-040) during calibration period 1999-2003.

[Recreational season is May 1 through October 15. FSTDEC, first order decay rate for fecal coliform; MON-GRND-CONC, monthly concentration of a quality constituent in active ground water; MON-IFLW-CONC, monthly concentration of a quality constituent in interflow; MON-ACCUM, monthly accumulation rates of a quality constituent; MON-SQOLIM, monthly limiting storage of a quality constituent; WSFAC, susceptibility of a quality constituent to washoff; na, not applicable.]

\begin{tabular}{|c|c|c|c|c|c|c|}
\hline $\begin{array}{c}\text { Water-quality } \\
\text { parameter } \\
\text { modified }\end{array}$ & $\begin{array}{l}\text { Multi- } \\
\text { plier }\end{array}$ & $\begin{array}{l}\text { Fecal coliform } \\
\text { load per recre- } \\
\text { ational season } \\
\text { at mouth of Mad } \\
\text { River, in } 10^{15} \\
\text { colonies }\end{array}$ & $\begin{array}{l}\text { Percent } \\
\text { of fecal } \\
\text { coliform } \\
\text { load from } \\
\text { calibrated } \\
\text { model } \\
\end{array}$ & $\begin{array}{l}\text { Multi- } \\
\text { plier }\end{array}$ & $\begin{array}{l}\text { Annual nitrate } \\
\text { load at mouth } \\
\text { of Mad River, } \\
\text { in thousands } \\
\text { of pounds }\end{array}$ & $\begin{array}{c}\text { Percent of } \\
\text { nitrate load } \\
\text { from calibrated } \\
\text { model }\end{array}$ \\
\hline $\begin{array}{l}\text { No changes } \\
\text { (Calibrated } \\
\text { model) } \\
\end{array}$ & na & 3.0 & 100 & na & 5,300 & 100 \\
\hline FSTDEC & $\begin{array}{r}2 \\
0.5\end{array}$ & $\begin{array}{l}1.8 \\
3.9\end{array}$ & $\begin{array}{r}60 \\
130\end{array}$ & $\begin{array}{l}\text { na } \\
\text { na }\end{array}$ & $\begin{array}{l}\text { na } \\
\text { na }\end{array}$ & $\begin{array}{l}\text { na } \\
\text { na }\end{array}$ \\
\hline $\begin{array}{l}\text { MON-GRND- } \\
\text { CONC }\end{array}$ & $\begin{array}{l}\text { na } \\
\text { na }\end{array}$ & $\begin{array}{l}\text { na } \\
\text { na }\end{array}$ & $\begin{array}{l}\text { na } \\
\text { na }\end{array}$ & $\begin{array}{r}2 \\
0.5\end{array}$ & $\begin{array}{l}7,100 \\
4,400\end{array}$ & $\begin{array}{r}134 \\
83\end{array}$ \\
\hline $\begin{array}{l}\text { MON-IFLW- } \\
\text { CONC }\end{array}$ & $\begin{array}{r}2 \\
0.5\end{array}$ & $\begin{array}{l}3.1 \\
2.9\end{array}$ & $\begin{array}{r}103 \\
97\end{array}$ & $\begin{array}{r}2 \\
0.5\end{array}$ & $\begin{array}{l}6,600 \\
4,700\end{array}$ & $\begin{array}{r}123 \\
87\end{array}$ \\
\hline MON-ACCUM & $\begin{array}{r}1.25 \\
0.5\end{array}$ & $\begin{array}{l}3.0 \\
3.1\end{array}$ & $\begin{array}{l}100 \\
103\end{array}$ & $\begin{array}{r}2 \\
0.5\end{array}$ & $\begin{array}{l}5,400 \\
5,900\end{array}$ & $\begin{array}{l}102 \\
111\end{array}$ \\
\hline MON-SQOLIM & $\begin{array}{r}2 \\
0.8\end{array}$ & $\begin{array}{l}3.5 \\
2.9\end{array}$ & $\begin{array}{r}117 \\
97\end{array}$ & $\begin{array}{r}2 \\
0.5\end{array}$ & $\begin{array}{l}6,600 \\
5,200\end{array}$ & $\begin{array}{r}122 \\
98\end{array}$ \\
\hline WSFAC & $\begin{array}{r}2 \\
0.5\end{array}$ & $\begin{array}{l}2.8 \\
3.3\end{array}$ & $\begin{array}{r}93 \\
110\end{array}$ & $\begin{array}{r}2 \\
0.5\end{array}$ & $\begin{array}{l}5,100 \\
5,600\end{array}$ & $\begin{array}{r}96 \\
106\end{array}$ \\
\hline
\end{tabular}

\section{Simulated Loads and Concentrations}

The calibrated HSPF model was able to simulate the loads of fecal coliform and nitrate from nonpoint sources such as failed septic systems, cattle in streams, fertilizer and manure applications, and atmospheric deposition, as well as point sources such as WWTP discharges and CSOs. The mean recreation-season loads of fecal coliform and annual nitrate from point and nonpoint sources combined were computed for each HU using the results of the HSPF model simulation.

\section{Fecal Coliform}

Nonpoint sources of fecal coliform include manure applications and wildlife and livestock wastes from grazing. On the basis of the results of model simulation, the greatest fecal coliform load from nonpoint sources came from pasture and agricultural lands (table 16). Agriculture and pasture lands contributed approximately 4.3 billion colonies per acre, whereas forests contributed approximately 25 million colonies per acre.

An analysis of simulation results indicated that CSOs were the largest point source of fecal coliform (table 17). HU 05080001-170-060 (Buck Creek) contributed the highest load of fecal coliform to the Mad River Basin from point sources; CSOs contributed 1,900 trillion fecal coliform colonies per recreation season, more than 99 percent of the fecal coliform load to this hydrologic unit (HU).

Table 18 lists the loads exiting each HU (which include all contributions upstream from the HUs) and the difference between the loads entering the individual HUs and the loads exiting the individual HUs. The HSPF model computed a 


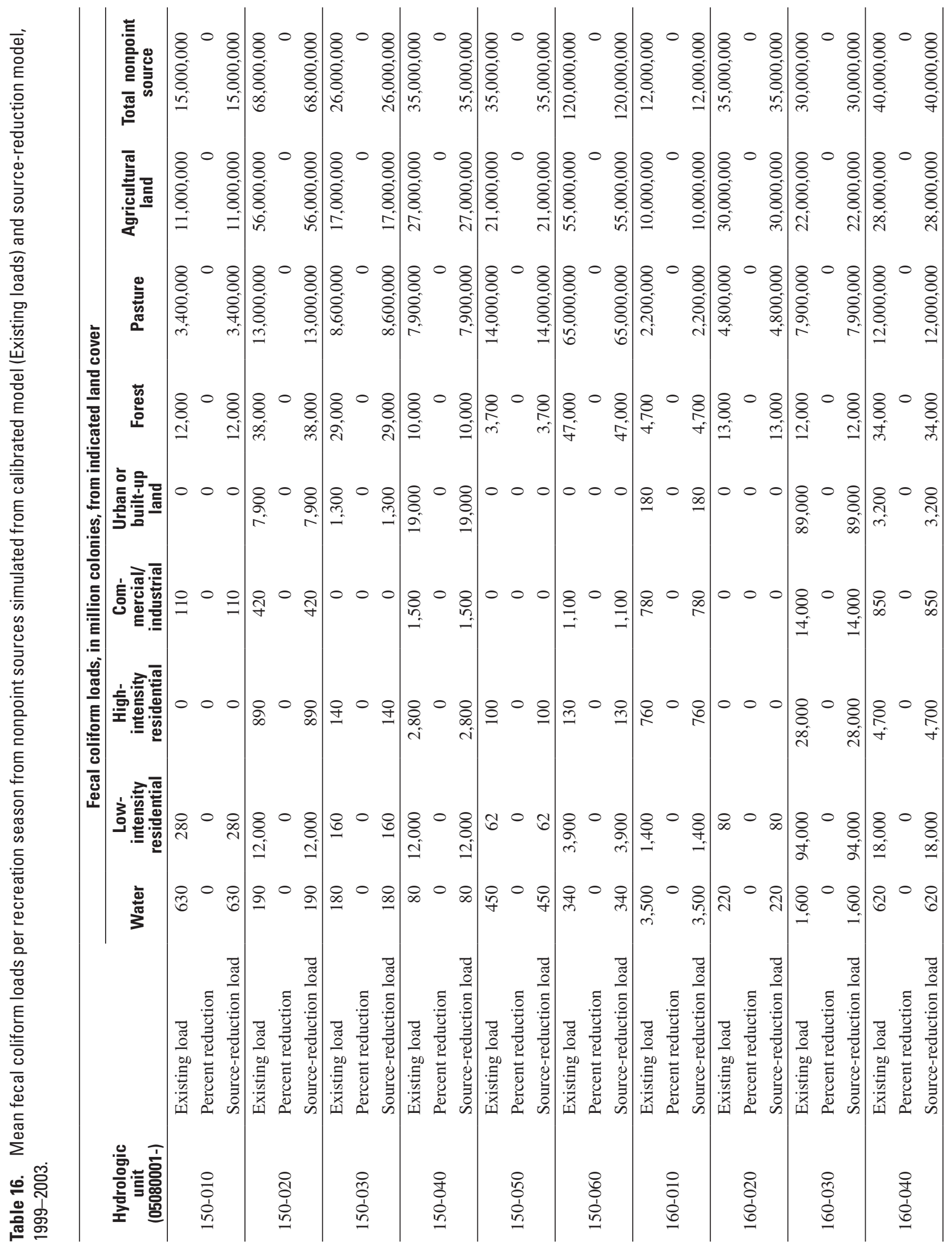




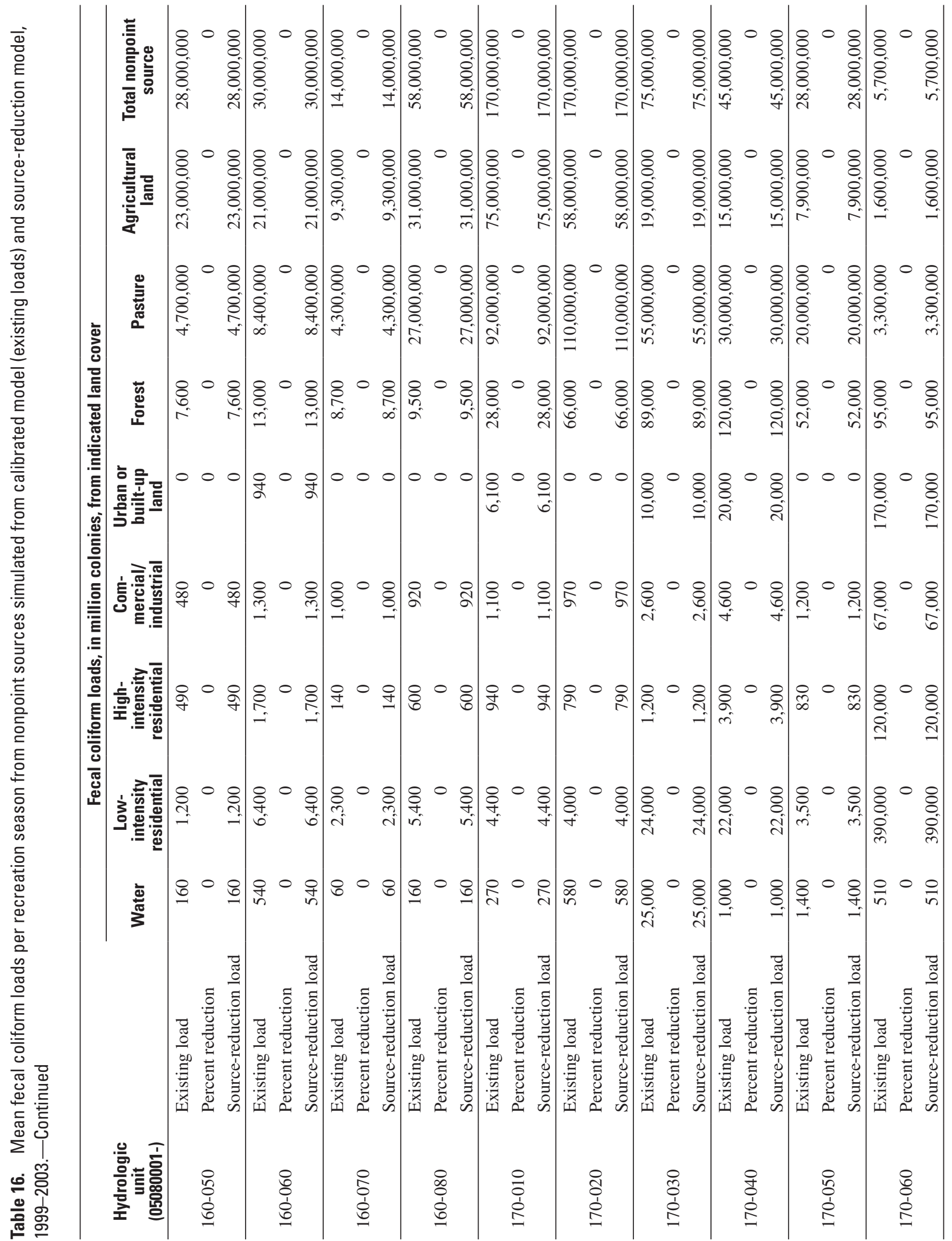




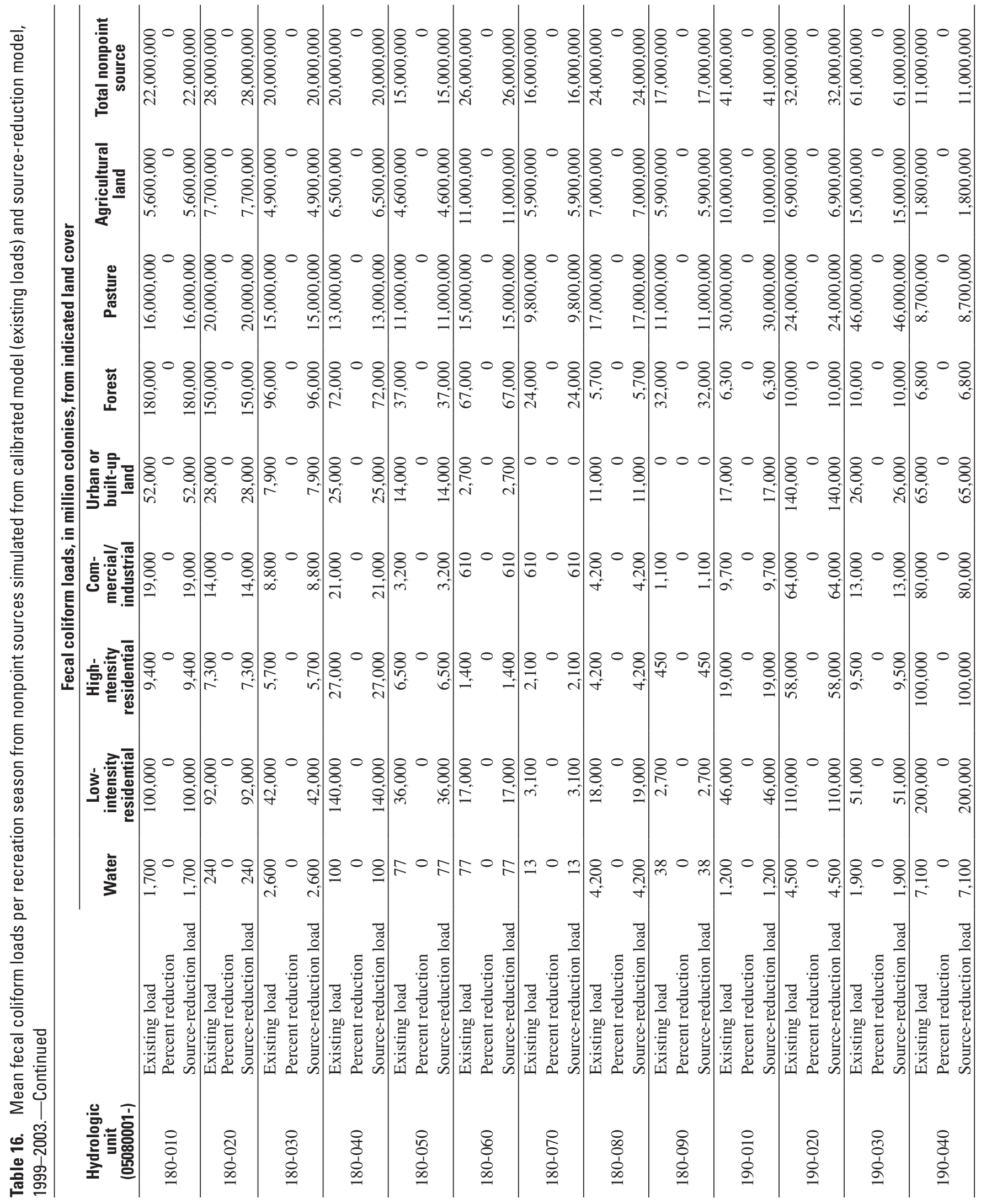




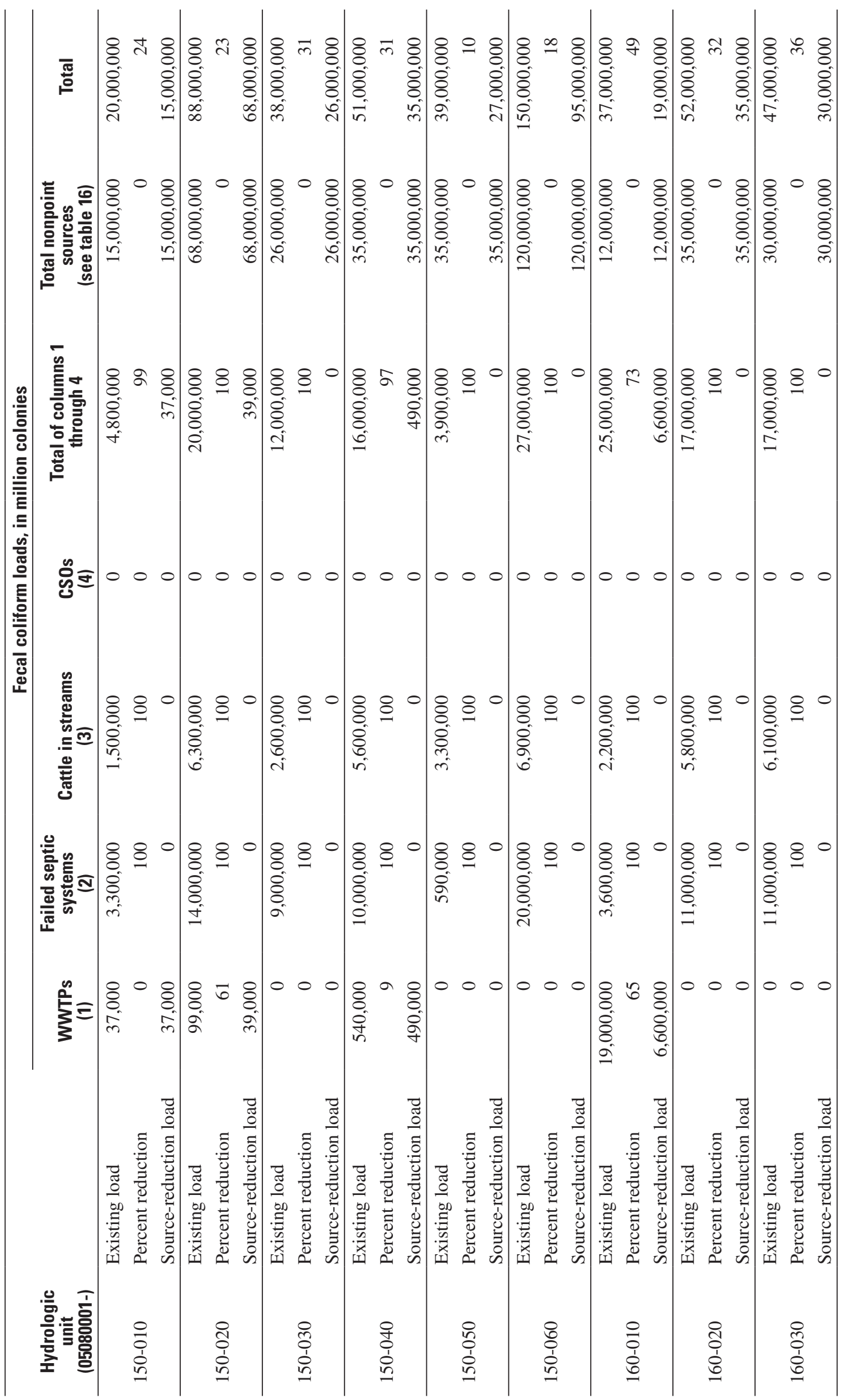




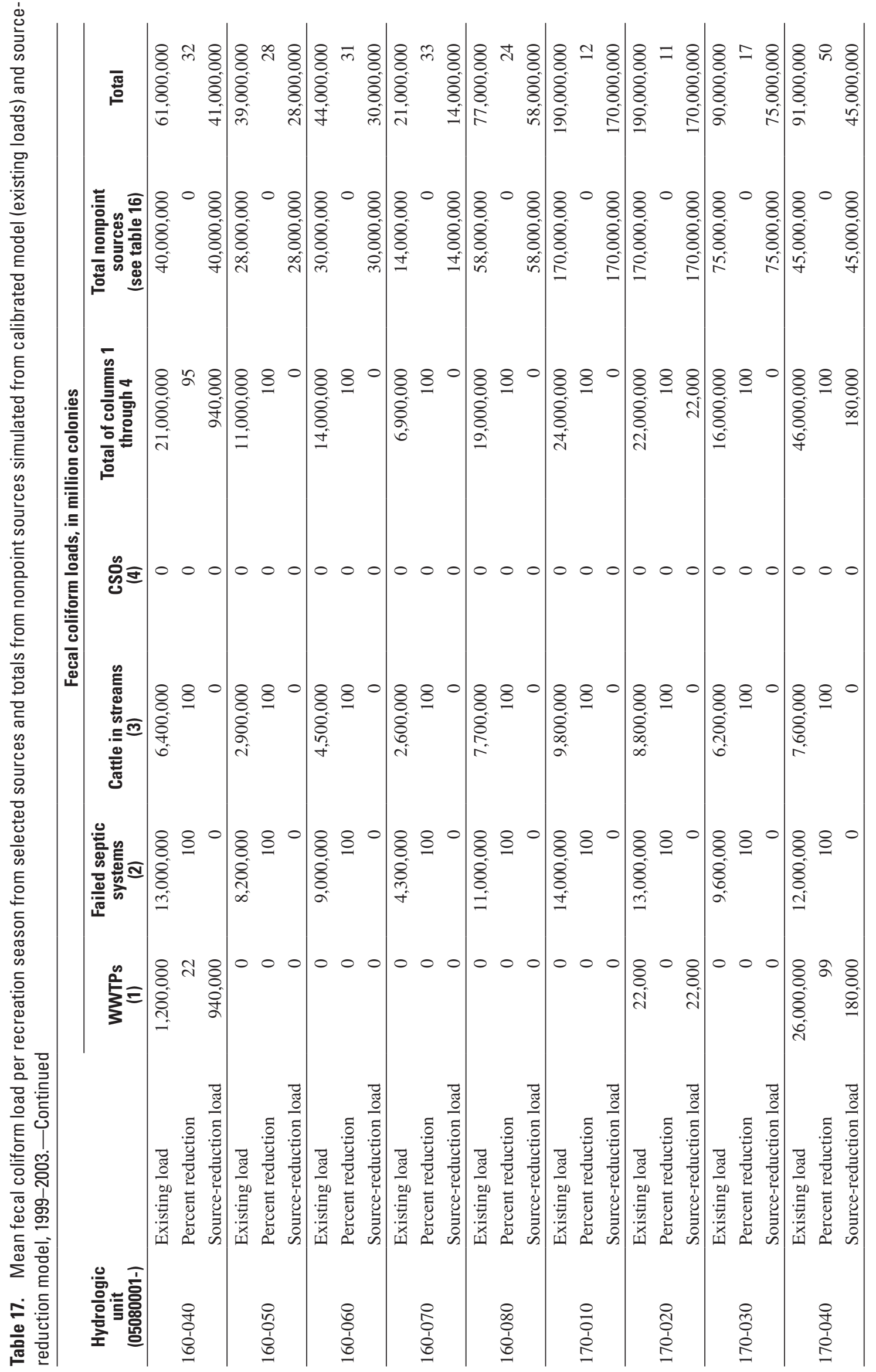




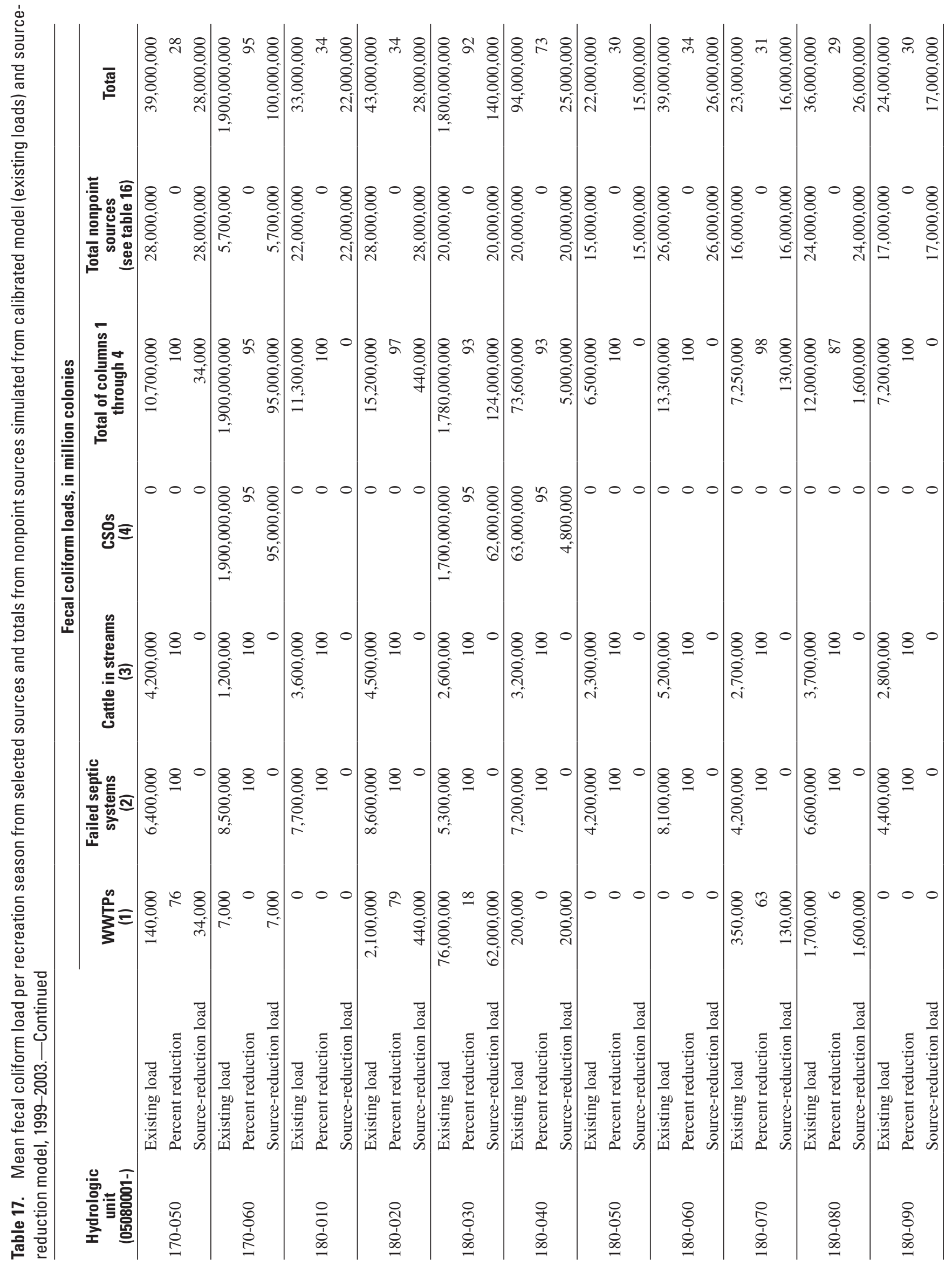




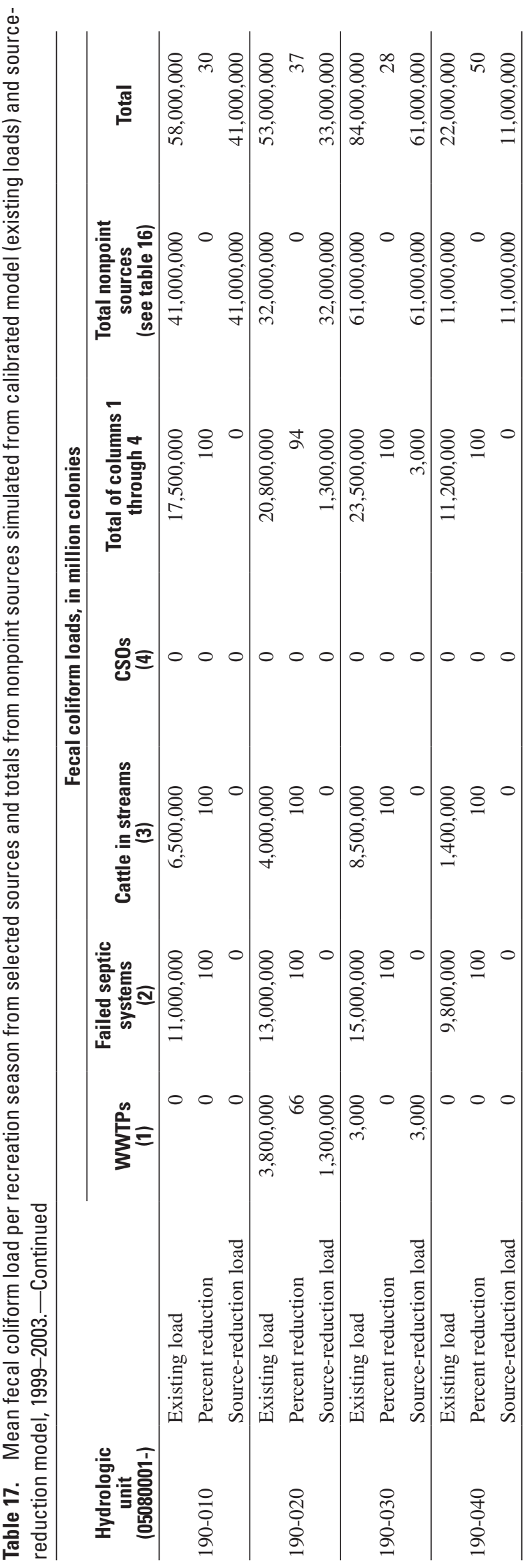

loss in fecal coliform load within HU 0508001-170-030 (the segment of Buck Creek in which C.J. Brown Reservoir is located). Losses in fecal coliform also were observed in the Mad River HUs downstream from the Donnels Creek confluence (0508001-180-080,-190-020, and -190-040). The loss of fecal coliform in these HUs is presumably due to die-off (decay). The Mad River HU (050880-180-030) immediately upstream from these HUs receives fecal coliform contributions from the Springfield CSOs and the Springfield WWTP-the largest combined loads of fecal coliform in the basin. The mean recreational-season load of fecal coliform exiting the Mad River Basin during the study period was approximately 3,000 trillion colonies (table 18). Of this load, the model indicated that point sources (WWTPs and CSOs) contributed 67 percent of the fecal coliform load in Mad River Basin streams.

Thirty-day geometric mean concentrations of fecal coliform were computed for each HU (table 19). The maximum fecal coliform concentrations were compared to numeric target of 1,000 col/100 mL. Simulated geometric mean counts that were greater than or equal to $1,000 \mathrm{col} / 100 \mathrm{~mL}$ are highlighted in bold in table 19. Concentrations exceeded the target in the HUs of Mad River below Kings Creek (05080001-160-010), Beaver Creek (05080001-170-040), Buck Creek (05080001170-060), Mill Creek (05080001-180-040), East Fork Donnels Creek (05080001-180-070) and the Mad River from Springfield to the mouth (05080001-180-030, -080, -190-020, -190040) (fig. 13). The greatest exceedance was in Beaver Creek, where simulated concentrations were approaching 5 times the target concentration and an 79 percent reduction would be needed to achieve the target of $1,000 \mathrm{col} / 100 \mathrm{~mL}$. However, Buck Creek below C.J. Brown Reservoir (05080001-170060) had the most exceedances of the target (37 percent of the simulation period) (table 19).

In general, HUs with geometric mean concentrations of fecal coliform exceeding the Ohio EPA target received discharges from CSOs and (or) major WWTPs (greater than $0.5 \mathrm{Mgal} / \mathrm{d}$ ). The exceptions to this are the Beaver Creek HU (05080001-170-040) and the Mad River HU that includes the city of Urbana (05080001-160-010). Both HUs had WWTPs (less than $0.5 \mathrm{Mgal} / \mathrm{d}$ ) with high fecal coliform concentrations recorded in their monthly operating report (MOR) during certain months within the simulation period.

\section{Nitrate}

Nonpoint sources of nitrate include fertilizer and manure applications, atmospheric deposition, wildlife, and agricultural livestock. The greatest total nitrate loads from nonpoint sources came from pasture and agricultural lands (table 20), which make up 75 percent of the Mad River Basin. On the basis of model simulation results, the highest nitrate loads per acre came from agricultural lands and residential areas. Agricultural and residential areas contributed approximately $13 \mathrm{lb} / \mathrm{acre}$ of nitrate, and forests contributed approximately $1.6 \mathrm{lb} / \mathrm{acre}$. 
Table 18. Fecal coliform and nitrate loads at outlet of each 14-digit hydrologic unit (includes all contributions upstream from hydrologic unit) and loads contributed by each hydrologic unit, 1999-2003 (simulated from calibrated model).

[Recreation season is May 1 through October 15. A negative load difference indicates losses due to chemical transformation, plant uptake, or die-off. HU, Hydrologic Unit; E.F., East Fork]

\begin{tabular}{|c|c|c|c|c|c|}
\hline \multirow[b]{2}{*}{ Stream } & \multirow[b]{2}{*}{$\begin{array}{l}\text { Hydrologic } \\
\text { unit code } \\
\text { (0508001-) }\end{array}$} & \multicolumn{2}{|c|}{$\begin{array}{l}\text { Mean fecal coliform load per rec- } \\
\text { reation season, in billion colonies }\end{array}$} & \multicolumn{2}{|c|}{$\begin{array}{l}\text { Mean nitrate load per year, } \\
\text { in } 1,000 \text { pounds }\end{array}$} \\
\hline & & $\begin{array}{l}\text { Load dis- } \\
\text { charged from } \\
\text { HU }\end{array}$ & $\begin{array}{l}\text { Load outflow- } \\
\text { inflow differ- } \\
\text { ence within } \\
\text { HU }\end{array}$ & $\begin{array}{l}\text { Load discharged } \\
\text { from HU }\end{array}$ & $\begin{array}{l}\text { Load outflow- } \\
\text { inflow difference } \\
\text { within HU }\end{array}$ \\
\hline Mad River & $150-010$ & 19,000 & 19,000 & 62 & 62 \\
\hline Mad River & $150-020$ & 110,000 & 87,000 & 340 & 280 \\
\hline Machochee Creek & $150-030$ & 37,000 & 37,000 & 120 & 120 \\
\hline Mad River & $150-040$ & 220,000 & 37,000 & 760 & 210 \\
\hline Glady Creek & $150-050$ & 39,000 & 39,000 & 83 & 83 \\
\hline Kings Creek & $150-060$ & 120,000 & 120,000 & 680 & 680 \\
\hline Mad River & $160-010$ & 460,000 & $-5,000$ & 2,100 & 150 \\
\hline Muddy Creek & $160-020$ & 51,000 & 51,000 & 170 & 170 \\
\hline Dugan Run & $160-030$ & 74,000 & 74,000 & 330 & 330 \\
\hline Nettle Creek & $160-040$ & 87,000 & 87,000 & 340 & 340 \\
\hline Anderson Creek & $160-050$ & 38,000 & 38,000 & 140 & 140 \\
\hline Mad River & $160-060$ & 600,000 & 19,000 & 2,600 & 140 \\
\hline Storms Creek & $160-070$ & 20,000 & 20,000 & 64 & 64 \\
\hline Chapman Creek & $160-080$ & 76,000 & 76,000 & 180 & 180 \\
\hline Buck Creek & $170-010$ & 180,000 & 180,000 & 620 & 620 \\
\hline E. F. Buck Creek & $170-020$ & 180,000 & 180,000 & 540 & 540 \\
\hline Buck Creek & $170-030$ & 51,000 & $-300,000$ & 430 & -730 \\
\hline Beaver Creek & $170-040$ & 93,000 & 56,000 & 91 & 61 \\
\hline Sinking Creek & $170-050$ & 37,000 & 37,000 & 30 & 30 \\
\hline Buck Creek & $170-060$ & $1,800,000$ & $1,600,000$ & 630 & 110 \\
\hline Mad River & $180-010$ & 730,000 & 4,000 & 2,800 & 67 \\
\hline Moore Run & $180-020$ & 43,000 & 43,000 & 53 & 53 \\
\hline Mad River & $180-030$ & $4,100,000$ & $1,500,000$ & 4,300 & 760 \\
\hline Mill Creek & $180-040$ & 86,000 & 86,000 & 54 & 54 \\
\hline Rock Run & $180-050$ & 19,000 & 19,000 & 22 & 22 \\
\hline Donnels Creek & $180-060$ & 52,000 & 32,000 & 58 & 58 \\
\hline E. F. Donnels Creek & $180-070$ & 20,000 & 20,000 & 22 & 22 \\
\hline Mad River & $180-080$ & $3,700,000$ & $-520,000$ & 4,600 & 190 \\
\hline Jackson Creek & $180-090$ & 24,000 & 24,000 & 20 & 20 \\
\hline Mud Creek & $190-010$ & 53,000 & 53,000 & 41 & 41 \\
\hline Mad River & $190-020$ & $3,700,000$ & $-70,000$ & 5,200 & 560 \\
\hline Mud Run & 190-030 & 60,000 & 60,000 & 49 & 49 \\
\hline Mad River & $190-040$ & $3,000,000$ & $-700,000$ & 5,300 & 100 \\
\hline
\end{tabular}


Table 19. Fecal coliform concentrations simulated from calibrated model, 1999-2003.

[Numbers in bold indicate mean fecal coliform concentration exceeded Ohio Environmental Protection Agency water-quality standard of 1,000 colonies per 100 milliliters for fecal coliform (based on a 30-day geometric mean); E. F., East Fork; C., Creek; col/100 mL, colonies per 100 milliliters; na, not applicable]

\begin{tabular}{|c|c|c|c|c|}
\hline Stream & $\begin{array}{l}\text { Hydrologic } \\
\text { unit code } \\
\text { [05080001-] }\end{array}$ & $\begin{array}{c}\text { Maximum } \\
\text { 30-day geo- } \\
\text { metric mean } \\
\text { fecal coliform } \\
\text { count (col/100 } \\
\mathrm{mL} \text { ) }\end{array}$ & $\begin{array}{l}\text { Percent of } 30 \text {-day } \\
\text { geometric mean } \\
\text { fecal coliform con- } \\
\text { centrations above } \\
1,000 \mathrm{col} / 100 \mathrm{~mL}\end{array}$ & $\begin{array}{l}\text { Percent reduction } \\
\text { needed to meet } \\
\text { target of } 1,000 \\
\text { col/100 mL for } \\
\text { maximum }\end{array}$ \\
\hline Mad River & $150-010$ & 480 & 0 & na \\
\hline Mad River & $150-020$ & 500 & 0 & na \\
\hline Machochee Creek & $150-030$ & 520 & 0 & na \\
\hline Mad River & $150-040$ & 440 & 0 & na \\
\hline Glady Creek & $150-050$ & 380 & 0 & na \\
\hline Kings Creek & $150-060$ & 370 & 0 & na \\
\hline Mad River & $160-010$ & 1,100 & 0.7 & 9 \\
\hline Muddy Creek & $160-020$ & 650 & 0 & na \\
\hline Dugan Run & $160-030$ & 580 & 0 & na \\
\hline Nettle Creek & $160-040$ & 440 & 0 & na \\
\hline Anderson Creek & $160-050$ & 540 & 0 & na \\
\hline Mad River & $160-060$ & 860 & 0 & na \\
\hline Storms Creek & $160-070$ & 660 & 0 & na \\
\hline Chapman Creek & $160-080$ & 670 & 0 & na \\
\hline Buck Creek & $170-010$ & 880 & 0 & na \\
\hline E. F. Buck Creek & $170-020$ & 840 & 0 & na \\
\hline Buck Creek & $170-030$ & 10 & 0 & na \\
\hline Beaver Creek & $170-040$ & 4,700 & 8 & 79 \\
\hline Sinking Creek & $170-050$ & 1,000 & 0 & na \\
\hline Buck Creek & $170-060$ & 3,700 & 37 & 73 \\
\hline Mad River & $180-010$ & 720 & 0 & na \\
\hline Moore Run & $180-020$ & 1,000 & 0.1 & na \\
\hline Mad River & $180-030$ & 2,100 & 31 & 52 \\
\hline Mill Creek & $180-040$ & 1,700 & 33 & 41 \\
\hline Rock Run & $180-050$ & 940 & 0 & na \\
\hline Donnels Creek & $180-060$ & 1,000 & 0 & na \\
\hline E. F. Donnels C. & $180-070$ & 1,200 & 3 & 17 \\
\hline Mad River & $180-080$ & 1,800 & 16 & 44 \\
\hline Jackson Creek & 180-090 & 1,000 & 0 & na \\
\hline Mud Creek & 190-010 & 700 & 0 & na \\
\hline Mad River & $190-020$ & 1,500 & 6 & 33 \\
\hline Mud Run & 190-030 & 750 & 0 & na \\
\hline Mad River & 190-040 & 1,200 & 1.6 & 17 \\
\hline
\end{tabular}



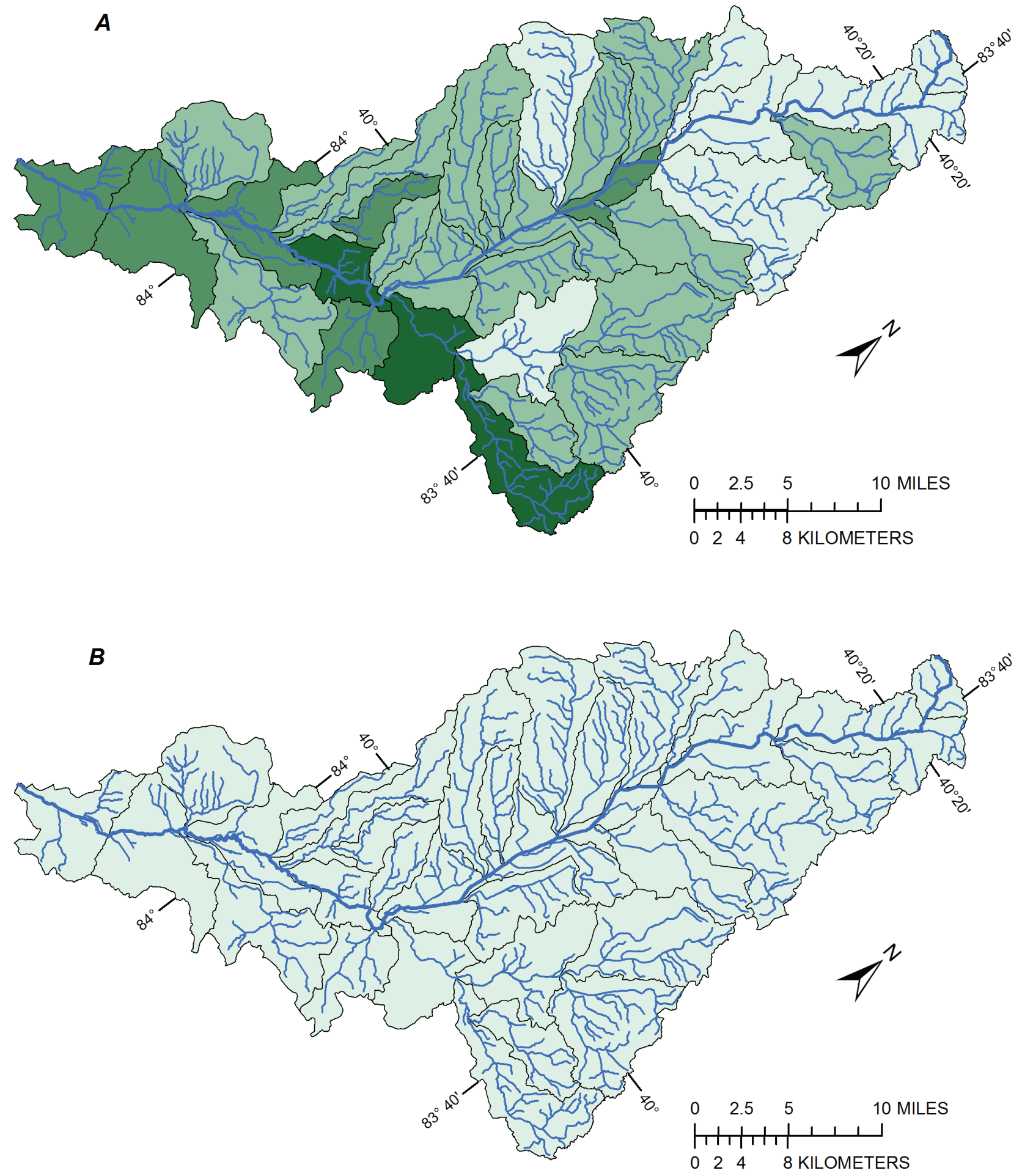

EXPLANATION

Fecal coliform concentration, in colonies per hundred milliliters

less than 500

$500-1000$

$1000-2000$

greater than 2000

Figure 13. Simulated maximum 30-day geometric mean concentrations of fecal coliform from $(A)$ calibrated model and $(B)$ source-reduction model, Mad River Basin, 1999-2003. 


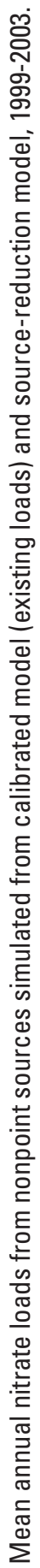

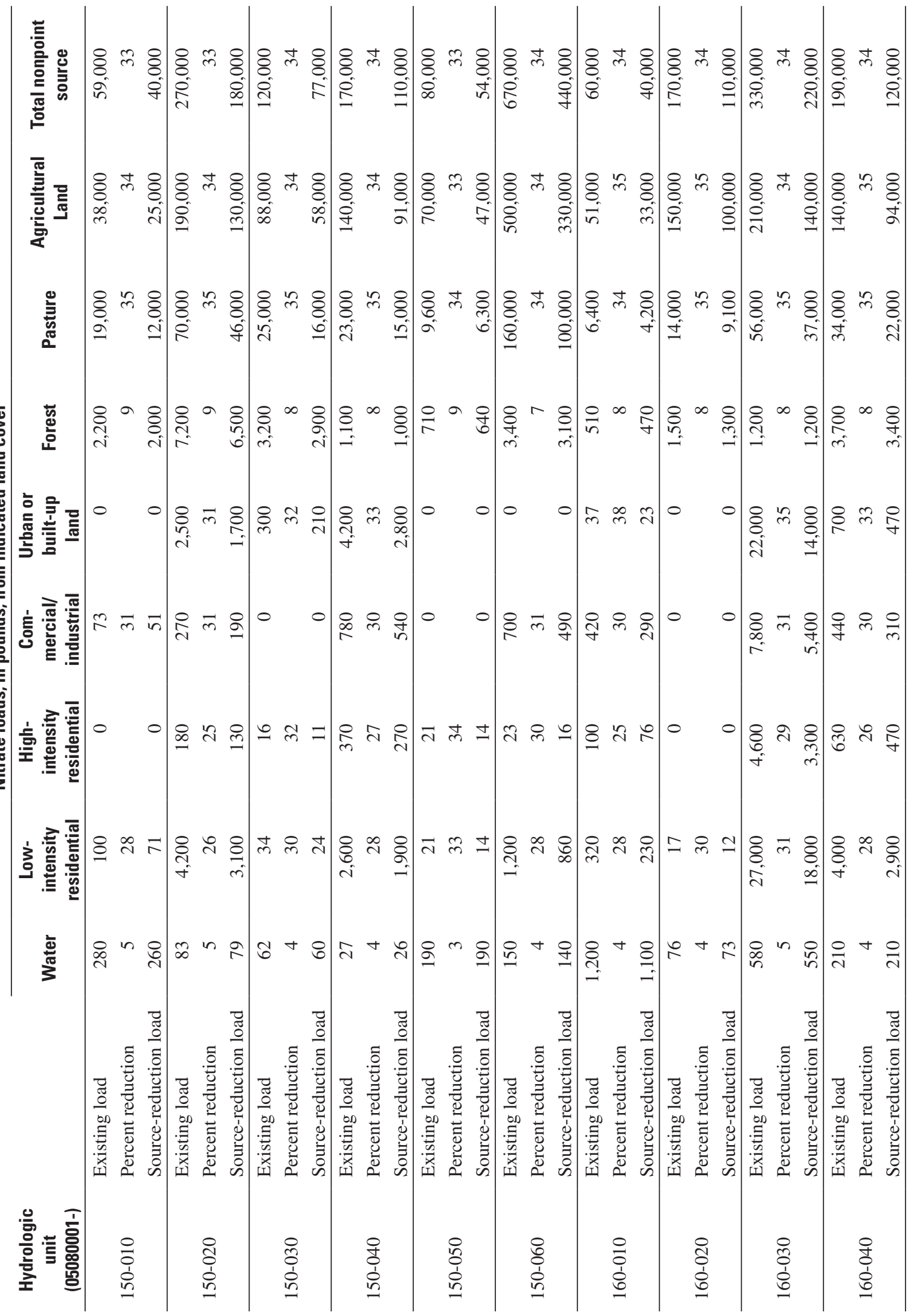




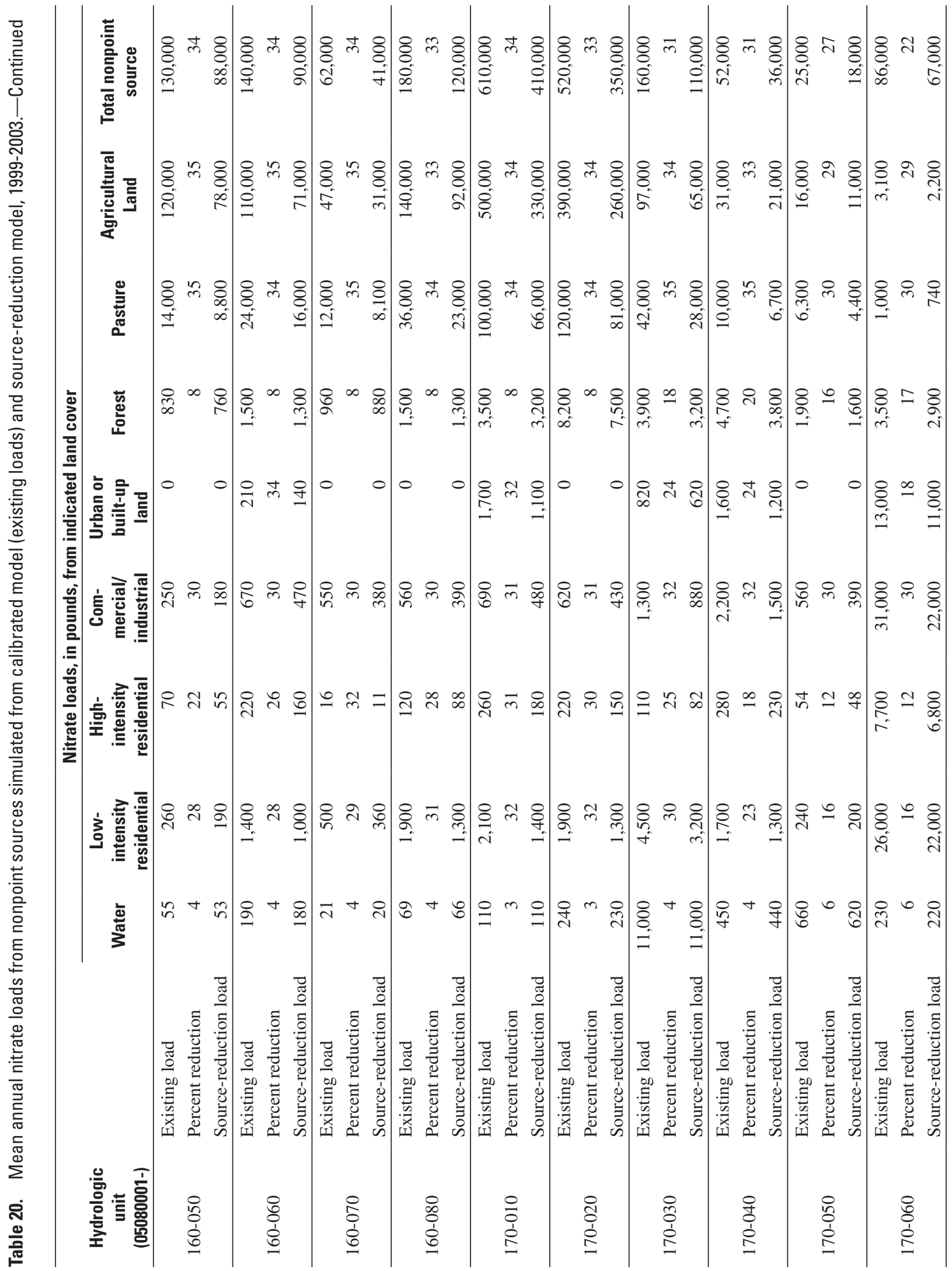




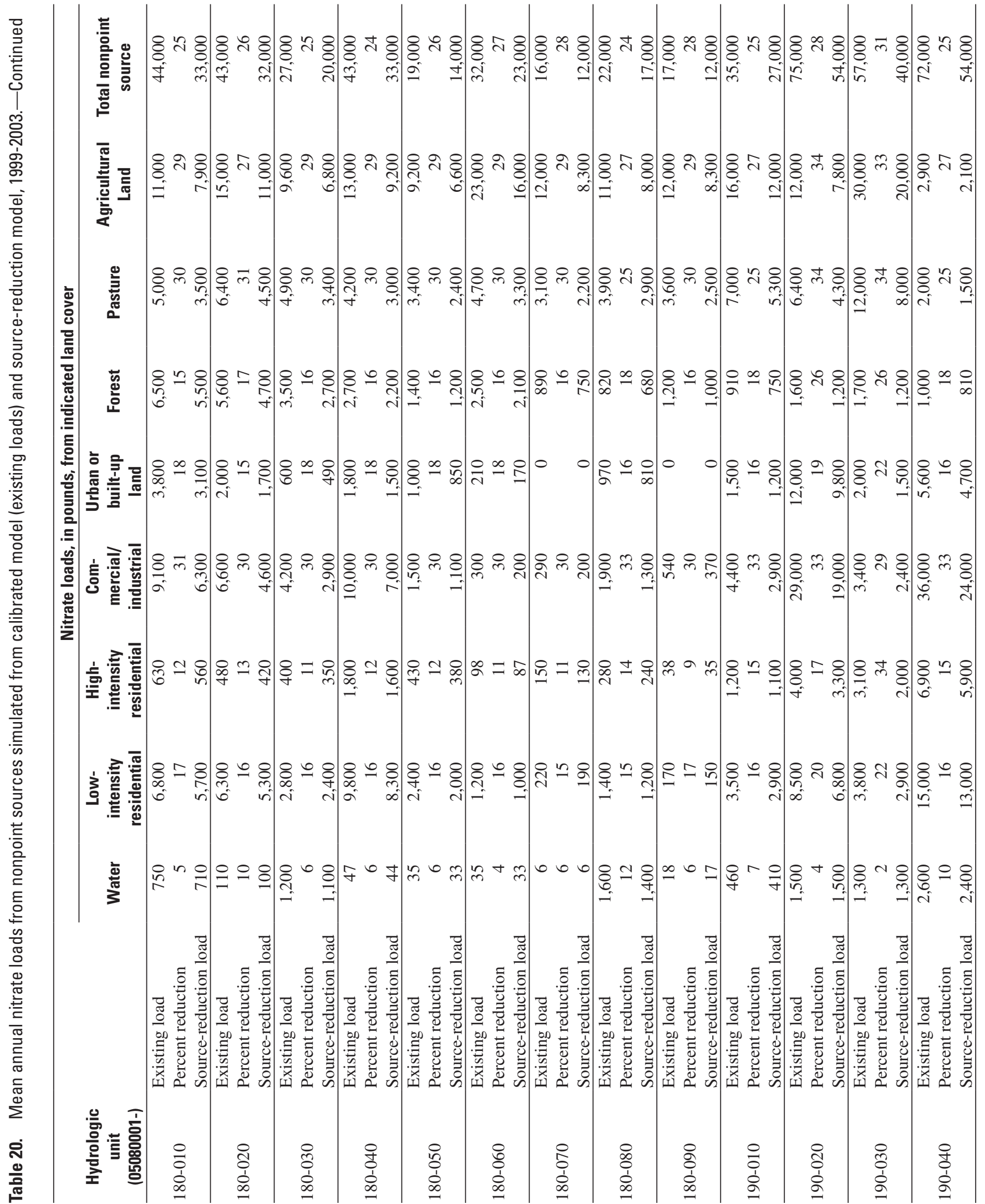


The simulation results indicated that WWTPs were the largest point source of nitrate (table 21). Mad River between Buck Creek confluence and Donnels Creek confluence (05080001-180-030) contributed the highest load of nitrate to the Mad River Basin from point sources. Wastewater treatment discharges (mainly the Springfield WWTP set to the design capacity) contributed $730,000 \mathrm{lb}$ annually, about 96 percent of the nitrate load to this HU.

The nitrate loads exiting the Mad River Basin during the study period were approximately 5.3 million pounds annually (table 18). The model indicates that nonpoint sources contributed 74 percent of the nitrate load.

Daily mean concentrations of nitrate were computed at the outlet of each HU for the model simulation period 1999-2003 (table 22). The daily mean nitrate concentration ranged from $8.7 \mathrm{mg} / \mathrm{L}$ for Buck Creek above C.J. Brown Reservoir (05080001-170-010) to $1.0 \mathrm{mg} / \mathrm{L}$ for Sinking Creek (05080001-170-050), Jackson Creek (05080001-180-090), and Mud Creek (05080001-190-010). Mean nitrate concentrations exceeded the target of $5 \mathrm{mg} / \mathrm{L}$ in the subbasins of Kings Creek, Dugan Run, Buck Creek, and East Fork Buck Creek (05080001-150-060, -160-030, -170-010, -170-020) (fig. 14). Reductions needed to meet the target are specified in table 22, with the largest percent reduction (42 percent) needed in Buck Creek above C.J. Brown Reservoir (05080001-170-010). This HU, along with Kings Creek (05080001-150-060) and East Fork Buck Creek (05080001-170-020) exceeded the target concentration through the entire simulation period (table 22).

All HUs with mean nitrate concentrations greater than $5.0 \mathrm{mg} / \mathrm{L}$ were in predominantly agricultural areas. The maximum daily mean nitrate concentrations simulated at these HUs were on days with streamflows greater than the 90th percentile for all HUs except Dugan Run (05080001-160-030). The maximum daily mean nitrate concentration simulated was 21 mg/L (February 9, 1999) for Anderson Creek (05080001160-050) and Nettle Creek (05080001-160-040).

\section{Result of Load-Reduction Simulations}

The Ohio EPA developed source-reduction scenarios for fecal coliform and nitrate in order to improve the water-quality conditions of streams in the Mad River Basin. HSPF models were revised to reflect changes associated with the sourcereduction scenarios to assess the probable effect of the reductions on instream loads.

\section{Fecal Coliform}

The source-reduction scenario for fecal coliform included the elimination of failing septic systems from the Mad River Basin, the elimination of direct access of cattle to streams, the reduction of fecal coliform loads from CSOs by 95 percent, and an improvement to WWTPs that would eliminate all 30 -day geometric mean exceedances of 1,000 col/100 mL in their effluent. The CSO loads were recomputed to adjust for a 95-percent reduction and stored in the WDM file. MORs from the WWTPs were reviewed, and all fecal coliform concentrations above $1,000 \mathrm{col} / 100 \mathrm{~mL}$ were lowered to $1,000 \mathrm{col} / 100$ $\mathrm{mL}$. The fecal coliform loads from these facilities were then recomputed on the basis of the lowered concentrations and entered as new time series in the WDM file.

Fecal coliform loads were computed for each HU from the revised model (table 23). The source-reduction model estimated that 810 trillion colonies would exit the Mad River Basin (HU 05080001-190-040), a 73-percent decrease in fecal coliform loads. The fecal-coliform-load reductions were not evenly distributed among the HUs. The elimination of failing septic systems and cattle in streams resulted in some reduction in the fecal coliform loads throughout the study area; however, the greatest load reductions of fecal coliform came from the 95-percent decrease in CSO loads, which had been identified as the largest source of fecal coliform by the calibrated model. The HUs affected by the CSO source reductions were only those in the vicinity of Springfield and the Mad River below Springfield.

As in the calibrated model, 30-day geometric mean fecal coliform concentrations for the source-reduction-scenario model were computed for each HU in the Mad River Basin (table 24). Target fecal coliform concentrations were not exceeded in any HUs in the source-reduction-scenario model. The maximum 30-day geometric mean fecal coliform concentration of $490 \mathrm{col} / 100 \mathrm{~mL}$ was simulated at Mad River below Springfield (HUC 05080001-180-030). This source-reduction scenario successfully lowered all stream concentrations below the target concentration for fecal coliform (fig. 13).

\section{Nitrate}

The source-reduction scenario for nitrate included the elimination of failing septic systems from the Mad River Basin, the elimination of direct access of cattle to streams, and a 30 percent reduction in nitrate runoff. This reduction scenario was selected by the Ohio EPA as part of a strategy established in the Mississippi River/Gulf of Mexico Watershed Nutrient Task Force Action Plan (2001) to reduce the hypoxia in the Gulf of Mexico. Because cattle in streams and failing septic systems were treated as point sources in the model, they could be removed by individual HU from the model. The reduction in nitrate runoff, however, required that a number of model parameters be altered for each model zone. These parameters included monthly interflow concentrations, monthly ground-water concentrations, maximum surface storage available for runoff, the accumulation rate of surface storage, and the susceptibility to washoff.

Nitrate loads were computed for each HU from the source-reduction model (table 23). The source-reduction model estimated that 2.6 million pounds of nitrate would exit the Mad River Basin (05080001-190-040), a 48-percent decrease in nitrate loads. Because most of the nitrate sources were evenly distributed across the study area, the percentage 


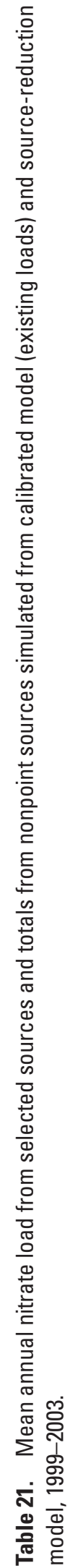

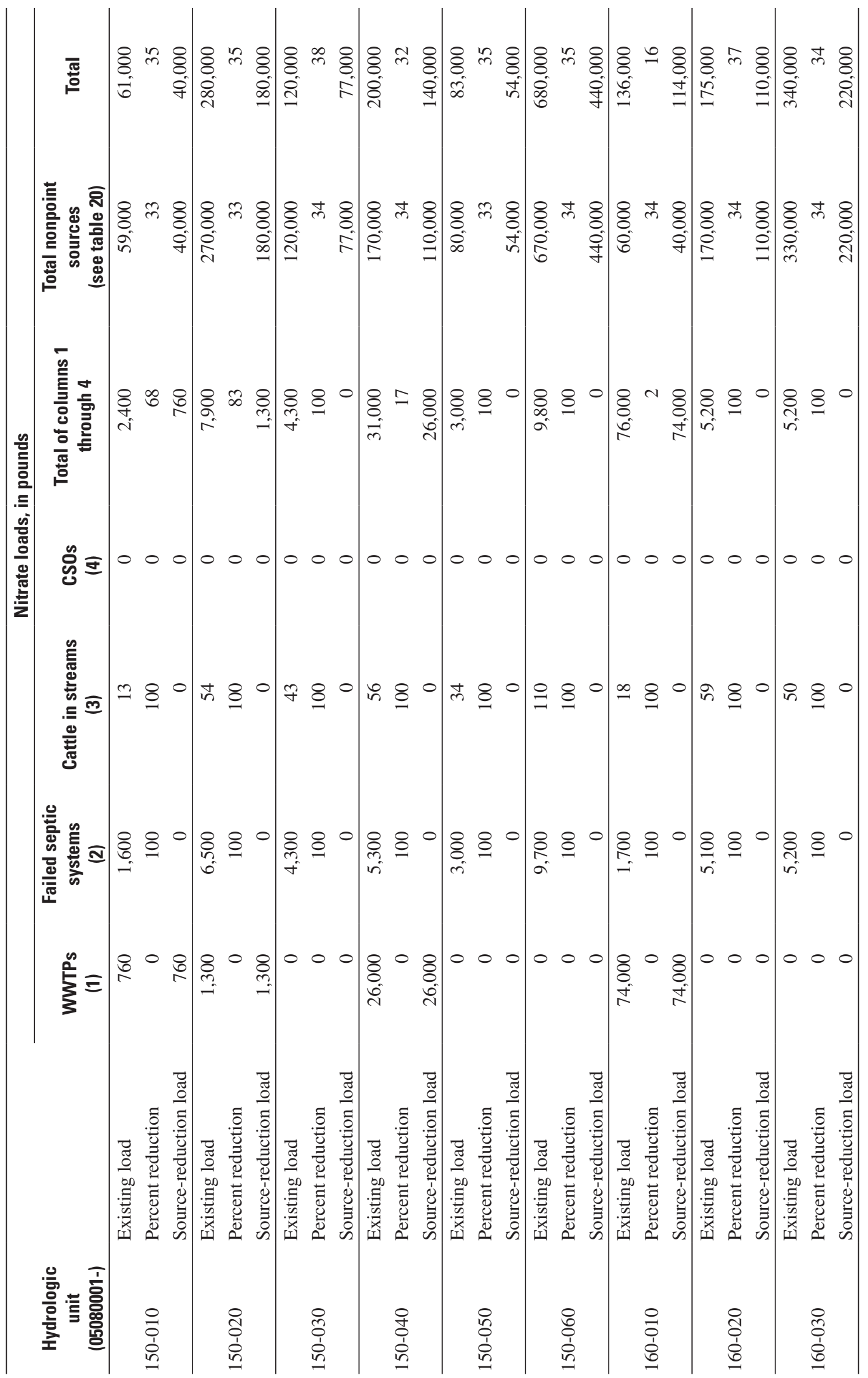




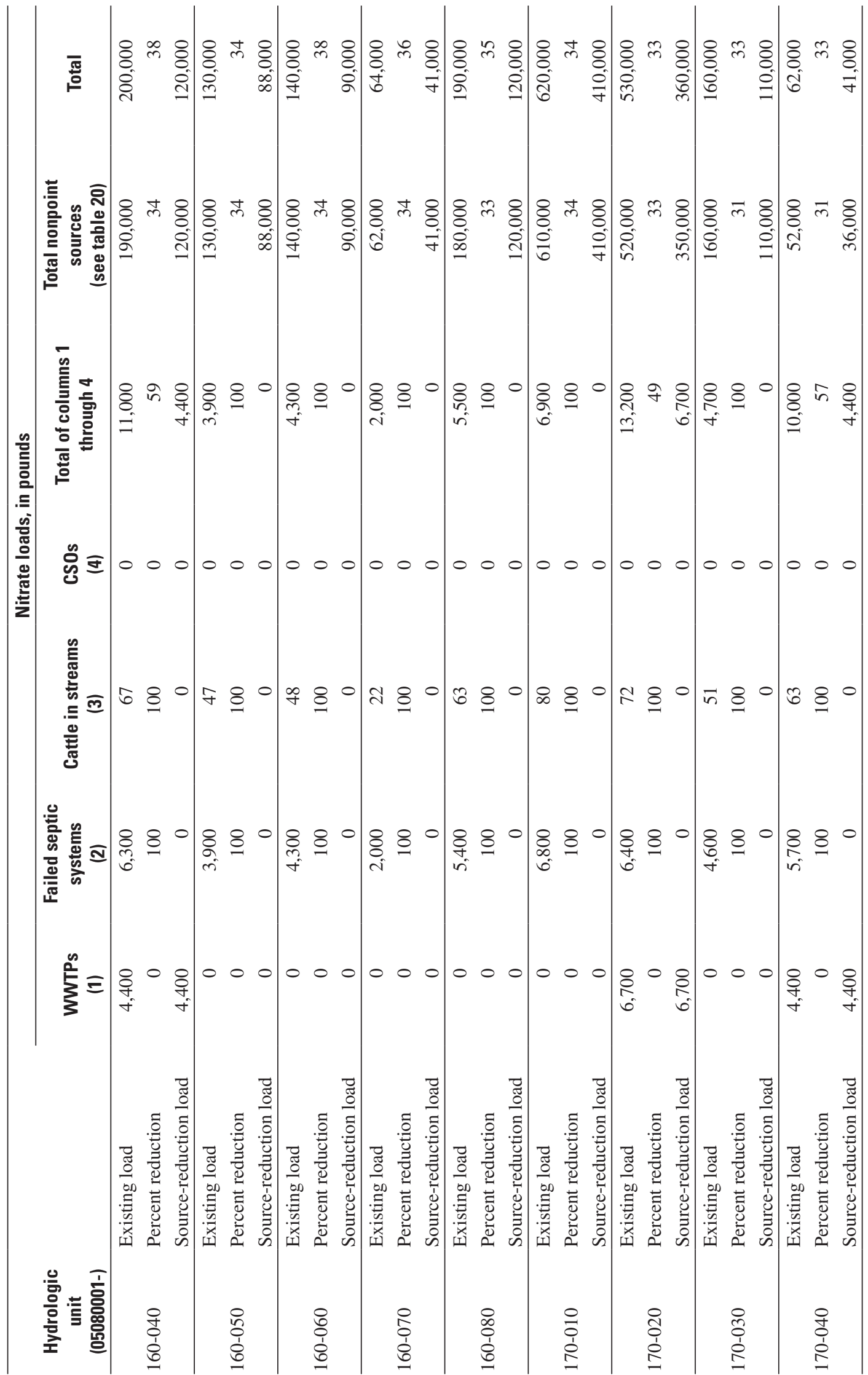




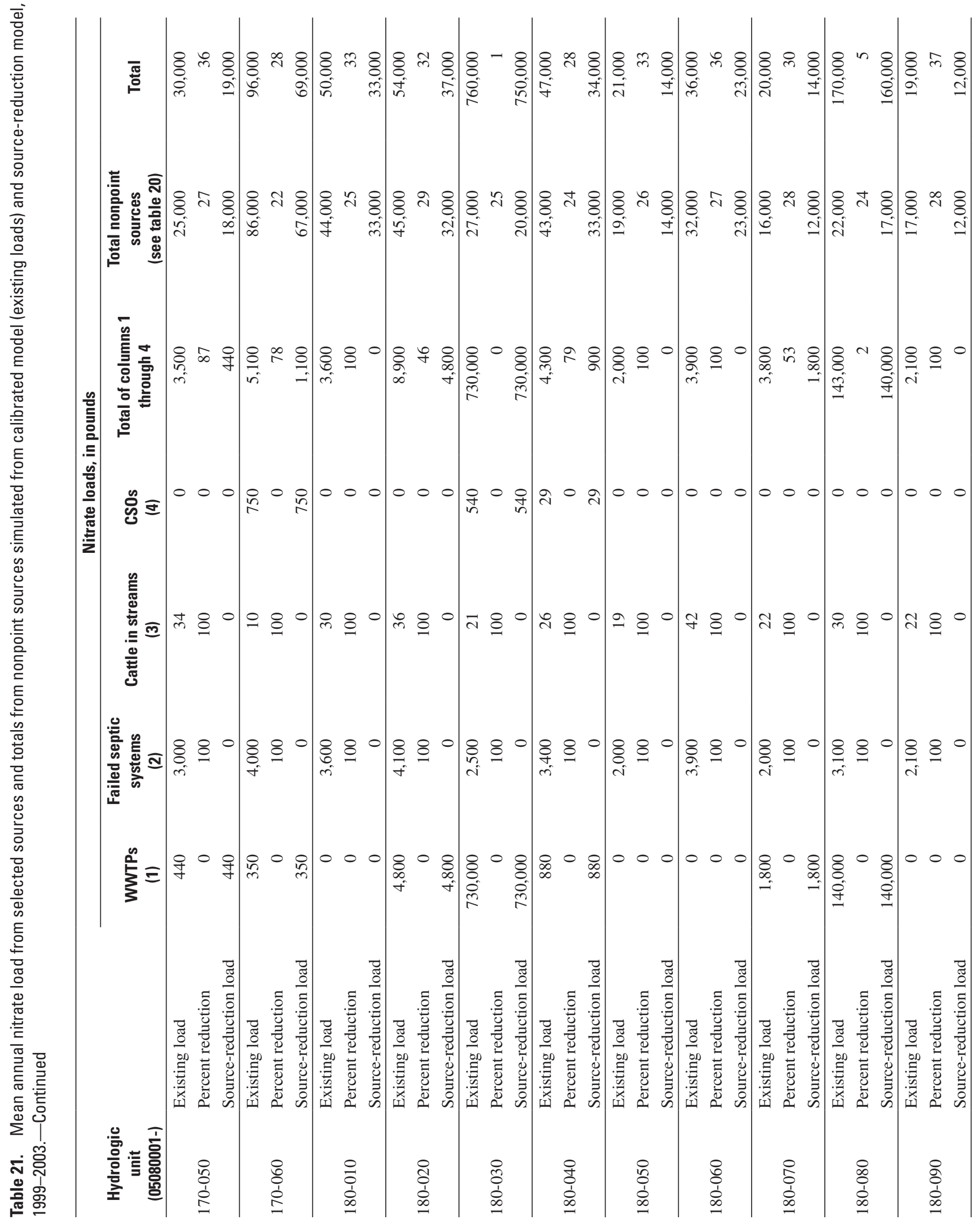




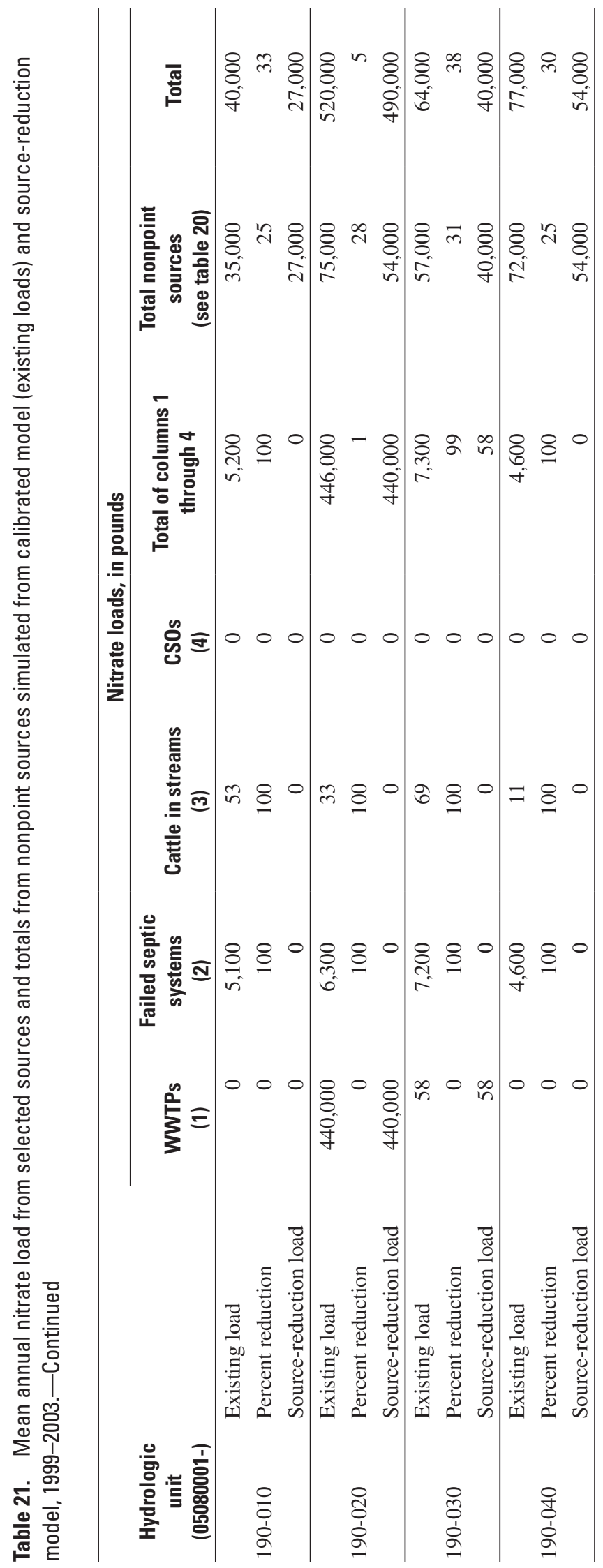


Table 22. Nitrate concentrations simulated from calibrated model, 1999-2003.

[Numbers in bold indicate mean nitrate concentration exceeded Ohio Environmental Protection Agency water-quality standard of $5 \mathrm{mg} / \mathrm{L}$ for nitrate; E. Fk., East Fork; Crk, Creek; mg/L, milligrams per liter; na, not applicable]

\begin{tabular}{|c|c|c|c|c|c|}
\hline Stream & $\begin{array}{c}\text { Hydrologic } \\
\text { unit } \\
\text { [05080001-] }\end{array}$ & $\begin{array}{c}\text { Maximum } \\
\text { nitrate concen- } \\
\text { tration (mg/L) }\end{array}$ & $\begin{array}{c}\text { Percent of } \\
\text { daily mean nitrate } \\
\text { concentrations } \\
\text { greater than } \\
5 \mathrm{mg} / \mathrm{L}\end{array}$ & $\begin{array}{l}\text { Mean nitrate con- } \\
\text { centration (mg/L) }\end{array}$ & $\begin{array}{l}\text { Percent reduc- } \\
\text { tion needed to } \\
\text { meet target of } \\
5 \mathrm{mg} / \mathrm{L} \text { for mean }\end{array}$ \\
\hline Mad River & $150-010$ & 5.3 & 0.6 & 3.4 & na \\
\hline Mad River & $150-020$ & 5.8 & 3.3 & 3.7 & na \\
\hline Machochee Creek & $150-030$ & 5.6 & 0.1 & 2.8 & na \\
\hline Mad River & $150-040$ & 11.4 & 0.3 & 3.6 & na \\
\hline Glady Creek & $150-050$ & 11.9 & 0.1 & 2.9 & na \\
\hline Kings Creek & $150-060$ & 10.8 & 100 & 7.6 & 34 \\
\hline Mad River & $160-010$ & 10.3 & 32 & 4.9 & na \\
\hline Muddy Creek & $160-020$ & 6.2 & 0.2 & 3.5 & na \\
\hline Dugan Run & $160-030$ & 10.7 & 99 & 6.1 & 18 \\
\hline Nettle Creek & $160-040$ & 21.3 & 0.6 & 3.3 & na \\
\hline Anderson Creek & $160-050$ & 21.4 & 0.7 & 3.6 & na \\
\hline Mad River & $160-060$ & 17 & 4.4 & 4.5 & na \\
\hline Storms Creek & $160-070$ & 10.8 & 0.1 & 3.1 & na \\
\hline Chapman Creek & $160-080$ & 6.1 & 2.2 & 3.1 & na \\
\hline Buck Creek & $170-010$ & 13.2 & 100 & 8.7 & 42 \\
\hline E. Fk. Buck Creek & $170-020$ & 12.2 & 100 & 8.0 & 38 \\
\hline Buck Creek & $170-030$ & 3.4 & 0 & 2.0 & na \\
\hline Beaver Creek & $170-040$ & 4.0 & 0 & 1.2 & na \\
\hline Sinking Creek & $170-050$ & 2.8 & 0 & 1.0 & na \\
\hline Buck Creek & $170-060$ & 7.9 & 0.1 & 1.8 & na \\
\hline Mad River & $180-010$ & 14.4 & 1.4 & 4.1 & na \\
\hline Moore Run & $180-020$ & 7.2 & 0.1 & 1.4 & na \\
\hline Mad River & $180-030$ & 7.9 & 11 & 4.2 & na \\
\hline Mill Creek & $180-040$ & 9.2 & 0.1 & 1.4 & na \\
\hline Rock Run & $180-050$ & 5.2 & 0.1 & 1.1 & na \\
\hline Donnels Creek & $180-060$ & 3.2 & 0 & 1.1 & na \\
\hline E. Fk. Donnels Crk & $180-070$ & 3.1 & 0 & 1.2 & na \\
\hline Mad River & $180-080$ & 8.2 & 11 & 4.1 & na \\
\hline Jackson Creek & $180-090$ & 2.8 & 0 & 1.0 & na \\
\hline Mud Creek & 190-010 & 7.1 & 0.1 & 1.0 & na \\
\hline Mad River & $190-020$ & 9.0 & 20 & 4.3 & na \\
\hline Mud Run & $190-030$ & 4.7 & 0 & 1.1 & na \\
\hline Mad River & $190-040$ & 9.0 & 17 & 4.1 & na \\
\hline
\end{tabular}



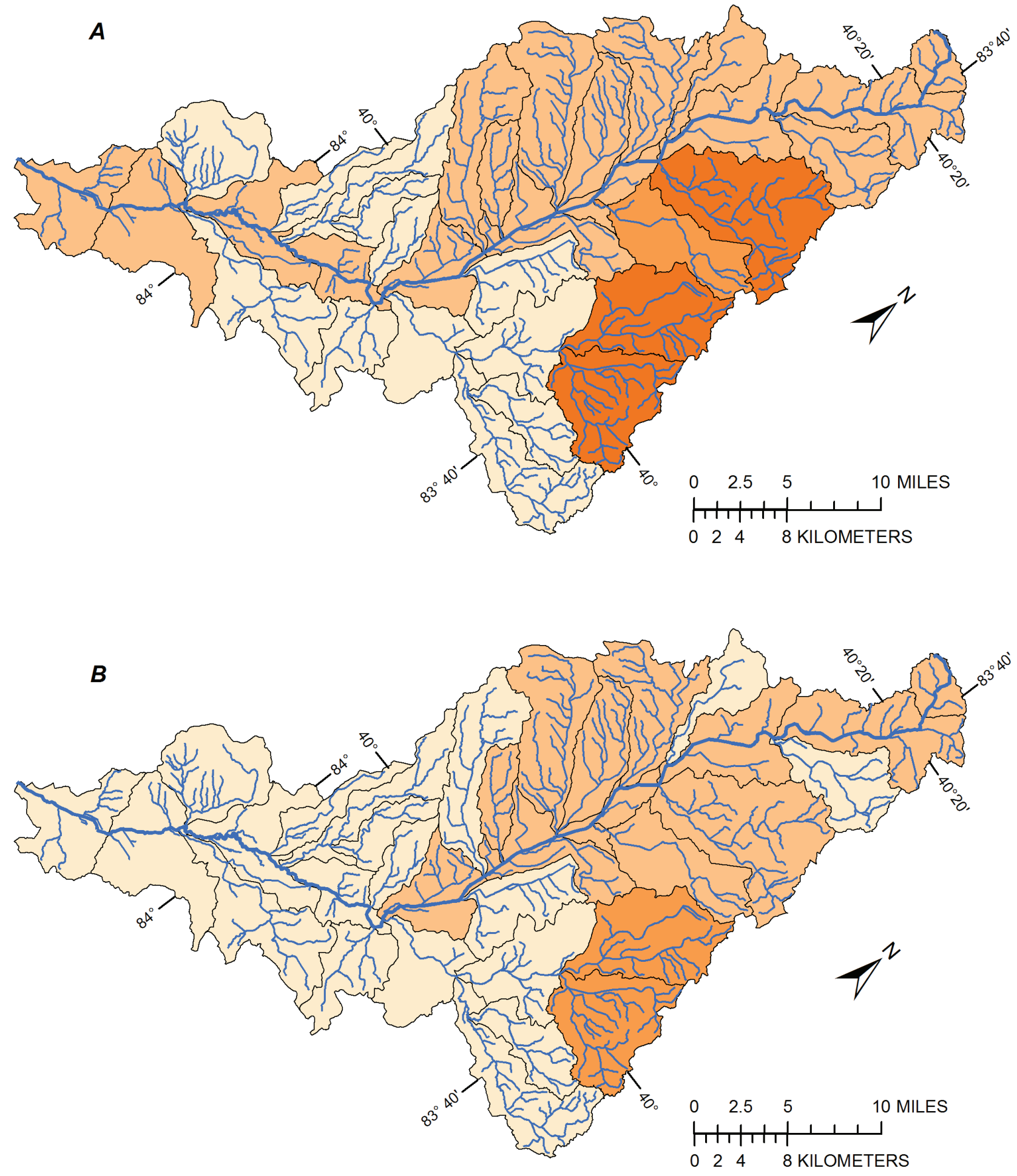

EXPLANATION

Nitrate concentration, in milligrams per liter less than 2 2-5 5-7 greater than 7

Figure 14. Simulated mean concentrations of nitrate from $(A)$ calibrated model and $(B)$ source-reduction model, Mad River Basin, 1999-2003. 
Table 23. Nitrate and fecal coliform loads at outlet of each 14-digit hydrologic unit (includes all contributions upstream from hydrologic unit) simulated from source-reduction model, 1999-2003.

[Recreation season is May 1 through October 15. A negative load difference indicates losses due to chemical transformation, plant uptake, or die-off. HU, Hydrologic unit]

\begin{tabular}{|c|c|c|c|c|c|}
\hline \multirow[b]{2}{*}{ Stream } & \multirow[b]{2}{*}{$\begin{array}{l}\text { Hydrologic } \\
\text { unit Code } \\
\text { (05080001-) }\end{array}$} & \multicolumn{2}{|c|}{$\begin{array}{c}\text { Mean fecal coliform load per } \\
\text { recreation season, } \\
\text { in billion colonies }\end{array}$} & \multicolumn{2}{|c|}{$\begin{array}{l}\text { Mean nitrate load per year, } \\
\text { in } 1,000 \text { pounds }\end{array}$} \\
\hline & & $\begin{array}{l}\text { Load dis- } \\
\text { charged from } \\
\text { HU }\end{array}$ & $\begin{array}{l}\text { Load outflow } \\
\text { - inflow differ- } \\
\text { ence within } \\
\text { HU }\end{array}$ & $\begin{array}{l}\text { Load dis- } \\
\text { charged from } \\
\text { HU }\end{array}$ & $\begin{array}{c}\text { Load outflow } \\
\text { - inflow differ- } \\
\text { ence within } \\
\text { HU }\end{array}$ \\
\hline Mad River & $150-010$ & 14,000 & 14,000 & 40 & 40 \\
\hline Mad River & $150-020$ & 82,000 & 67,000 & 220 & 180 \\
\hline Machochee Creek & $150-030$ & 33,000 & 33,000 & 77 & 77 \\
\hline Mad River & $150-040$ & 220,000 & 69,000 & 470 & 110 \\
\hline Glady Creek & $150-050$ & 42,000 & 42,000 & 54 & 54 \\
\hline Kings Creek & $150-060$ & 100,000 & 100,000 & 440 & 440 \\
\hline Mad River & $160-010$ & 350,000 & $-68,000$ & 1,300 & 44 \\
\hline Muddy Creek & $160-020$ & 35,000 & 35,000 & 110 & 110 \\
\hline Dugan Run & $160-030$ & 58,000 & 58,000 & 220 & 220 \\
\hline Nettle Creek & $160-040$ & 61,000 & 61,000 & 220 & 220 \\
\hline Anderson Creek & $160-050$ & 26,000 & 26,000 & 90 & 90 \\
\hline Mad River & $160-060$ & 450,000 & 12,000 & 1,600 & 41 \\
\hline Storms Creek & $160-070$ & 13,000 & 13,000 & 41 & 41 \\
\hline Chapman Creek & $160-080$ & 57,000 & 57,000 & 120 & 120 \\
\hline Buck Creek & $170-010$ & 160,000 & 160,000 & 410 & 410 \\
\hline East Fork Buck Creek & $170-020$ & 160,000 & 160,000 & 350 & 350 \\
\hline Buck Creek & $170-030$ & 51,000 & $-260,000$ & 290 & -470 \\
\hline Beaver Creek & $170-040$ & 55,000 & 28,000 & 57 & 38 \\
\hline Sinking Creek & $170-050$ & 27,000 & 27,000 & 19 & 19 \\
\hline Buck Creek & $170-060$ & 180,000 & 76,000 & 420 & 72 \\
\hline Mad River & 180-010 & 540,000 & 5,000 & 1,800 & 34 \\
\hline Moore Run & $180-020$ & 29,000 & 29,000 & 33 & 33 \\
\hline Mad River & $180-030$ & 900,000 & 140,000 & 2,300 & 22 \\
\hline Mill Creek & $180-040$ & 20,000 & 20,000 & 39 & 39 \\
\hline Rock Run & $180-050$ & 14,000 & 14,000 & 15 & 15 \\
\hline Donnels Creek & $180-060$ & 36,000 & 22,000 & 37 & 24 \\
\hline East Fork Donnels Creek & $180-070$ & 14,000 & 14,000 & 13 & 13 \\
\hline Mad River & $180-080$ & 890,000 & $-61,000$ & 2,400 & 27 \\
\hline Jackson Creek & $180-090$ & 17,000 & 17,000 & 13 & 13 \\
\hline Mud Creek & 190-010 & 38,000 & 38,000 & 27 & 27 \\
\hline Mad River & 190-020 & 950,000 & $-19,000$ & 2,500 & 58 \\
\hline Mud Run & 190-030 & 41,000 & 41,000 & 32 & 32 \\
\hline Mad River & 190-040 & 810,000 & $-140,000$ & 2,600 & 58 \\
\hline
\end{tabular}


Table 24. Fecal coliform and nitrate concentrations by 14-digit hydrologic unit simulated from source-reduction model, 1999-2003.

[See text for explanation of reduced-source scenario; numbers in bold indicate mean nitrate concentration exceeded Ohio EPA water-quality standard; E. Fk., East Fork; Crk, Creek; col, colonies; mL, milliliter; mg/L, milligrams per liter; na, not applicable]

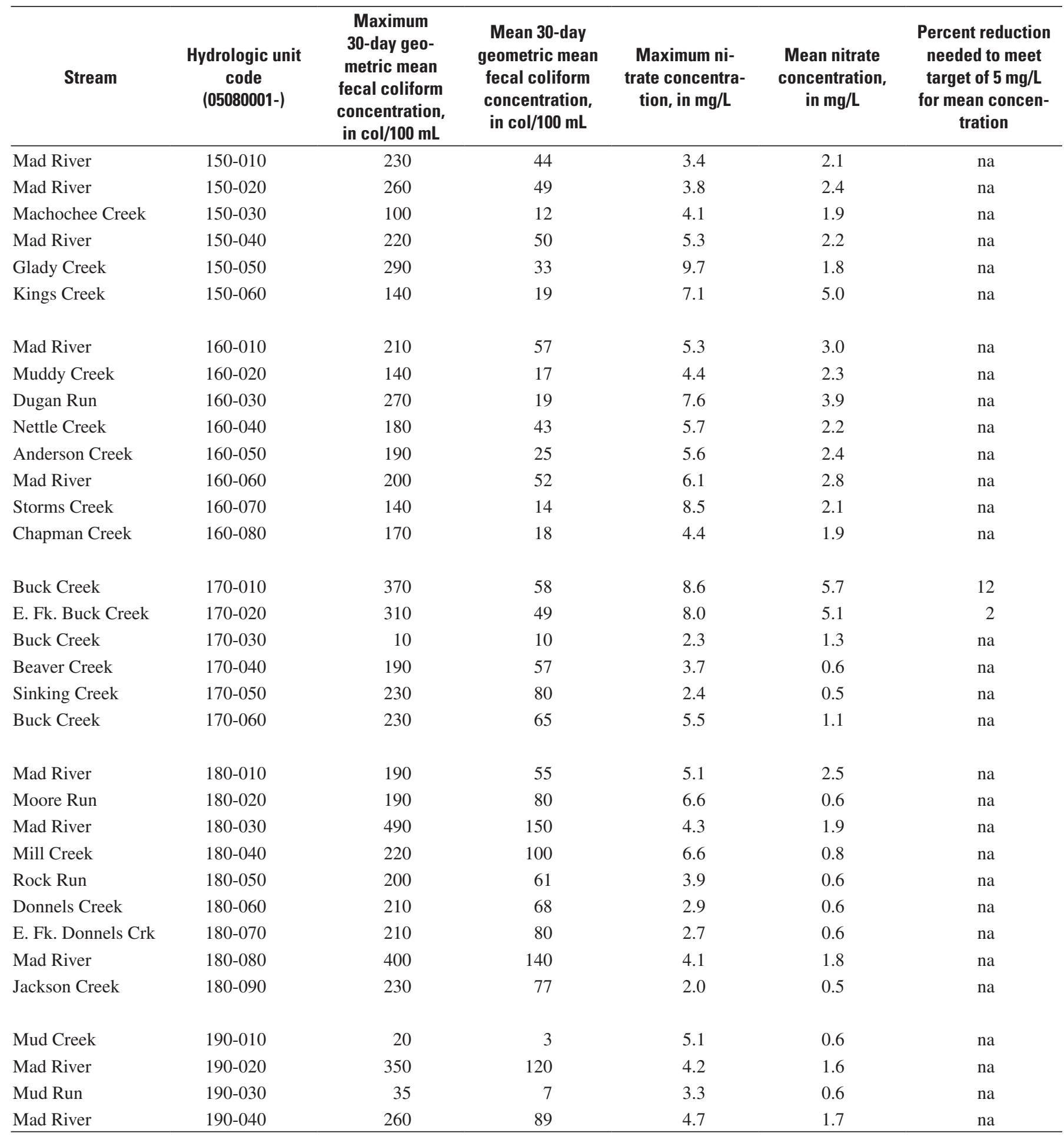


of nitrate reductions within each HU was relatively consistent (table 20; table 23).

Daily mean nitrate concentrations were computed for each HU for 1999-2003 on the basis of the source-reduction scenario. The mean nitrate concentrations ranged from $5.7 \mathrm{mg} / \mathrm{L}$ for Buck Creek above C.J. Brown Reservoir (HU 05080001-170-010) to $0.5 \mathrm{mg} / \mathrm{L}$ for Jackson Creek (HU 05080001-180-090) and Sinking Creek (HU 05080001-170050). The maximum daily mean nitrate concentration simulated was $9.7 \mathrm{mg} / \mathrm{L}$ (August 3, 2001) for Glady Creek (HU 05080001-150-050); however, the mean daily concentration in Glady Creek $(1.8 \mathrm{~m} / \mathrm{L})$ was below the target concentration. Additional load reductions are necessary to decrease mean nitrate concentrations to meet the nitrate target in the subbasins of Buck Creek and East Fork Buck Creek (HUs 05080001-170-010 and -170-020) (fig 14). To meet the nitrate target, further reductions of 12 and 2 percent, respectively, are needed in these subbasins (table 24).

\section{TMDL Requirements}

The calibrated water-quality model will be used by Ohio EPA to establish the TMDL for the Mad River Basin. The model must adequately simulate streamflow conditions during which the highest nitrate concentrations and fecal coliform counts occur. To calculate the TMDL, loads from all point sources, nonpoint sources, and natural background sources are summed. (See "Simulated Loads and Concentrations" section of this report.) The TMDL must include a margin of safety (MOS) that accounts for uncertainties inherent in the model and calibration data. The summed loads, with the incorporated MOS, are then converted to concentrations and are compared to target concentrations for fecal coliform bacteria and nitrate (based on Ohio WQS, where applicable) to determine whether the loads from the various sources in the basin can be sufficiently assimilated to allow all stream segments to meet their designated uses. If simulated concentrations of fecal coliform and nitrate exceed target concentrations, load-reduction scenarios must be considered that, if implemented, would result in meeting target concentrations. A load-reduction scenario that results in meeting target concentrations may then be selected by Ohio EPA and designated as the TMDL for the Mad River Basin.

\section{Seasonal and Streamflow Variability}

Seasonal variability in nitrate concentrations was neither indicated by the model nor evident from the observed data from the Mad River at St. Paris Pike streamflow gage. The absence of variability is likely due to the large ground-water component of streamflow, which delivers a relatively constant load of nitrate to the streams in the Mad River Basin. Seasonal variability in fecal coliform concentrations was not addressed in this study because the model was calibrated for the recreation season only (May $1^{\text {st }}$ through October $\left.15^{\text {th }}\right)$. Further, linear regression of fecal coliform or nitrate concentrations on daily streamflow for each HU produced coefficients of determination $\left(\mathrm{R}^{2}\right)$ values of less than 0.3 for fecal coliform (during recreation season) and 0.4 for nitrate (during entire year), indicating a weak association of fecal coliform and nitrate concentrations with streamflow. However, when fecal coliform counts and nitrate concentrations were grouped as to whether or not the streamflows were at the highest 10-percent flows, the Wilcoxon-rank statistical test showed that the fecal coliform and nitrate concentrations were significantly higher during high streamflows at the Mad River at St. Paris Pike streamflow gage (results not presented herein).

\section{Margin of Safety}

A margin of safety was incorporated implicitly into the model from two model inputs. The failure rate of septic systems was set high ( 90 percent), given the predominant soil conditions in the Mad River Basin that are unfavorable for conventional leach-line septic systems. In addition, the discharge volumes of the five largest WWTP dischargers (with design capacity discharges of $0.5 \mathrm{Mgal} / \mathrm{d}$ or greater) were set at their design capacities, which were 25 to 67 percent greater than their present discharge volumes (table 8).

\section{Target Concentrations}

Target concentrations for the TMDLs were selected by Ohio EPA. The targets for fecal coliform concentrations for the protection of recreational water quality are stated in the Ohio WQS (Ohio Environmental Protection Agency, 2002). For primary contact waters, fecal coliform bacteria cannot exceed $2,000 \mathrm{col} / 100 \mathrm{~mL}$ in more than 10 percent of the samples collected during a 30-day period. Also, the geometric mean of the fecal coliform concentrations cannot exceed 1,000 col/100 mL (from at least five samples collected within a 30-day period) (Ohio Environmental Protection Agency, 2002). On the basis of changes to recreational use designations that were recently recommended by Ohio EPA (2005a), almost all waters in the Mad River Basin are currently considered primary contact waters. The exception is the West Liberty tributary. Although this tributary has a designated recreational use of secondary contact, it was aggregated with other streams in HU 005080001-150-040 in the model that have primary contact use designation. Therefore, the more stringent target specified for primary contact waters was applied to this HU as well as to all other HUs in the basin.

The target concentration for nitrate modeling was more difficult to determine. The Ohio WQS does not list a statewide numeric criterion for nitrate for the protection of aquatic life. Therefore, Ohio EPA established, for purposes of this study, a target mean nitrate concentration of $5 \mathrm{mg} / \mathrm{L}$ in the Mad River Basin that corresponds to a public-water-supply "action alert" that is equal to 50 percent of the Maximum Contaminant Level for drinking water (Ohio Environmental Protection Agency, 2005b). 


\section{Summary and Conclusions}

The U.S. Geological Survey (USGS), in cooperation with the Ohio Environmental Protection Agency (Ohio EPA), developed a Hydrological Simulation Program-FORTRAN (HSPF) model to aid in total maximum daily load (TMDL) determinations for fecal coliform and nitrate in the Mad River Basin. The HSPF model simulated fecal coliform and nitrate loads at the outlet of each 14-digit Hydrologic Unit within the Mad River Basin.

The HSPF model included inputs from 32 WWTPs (5 of which had design capacities of $0.5 \mathrm{Mgal} / \mathrm{d}$ or greater), CSOs within the City of Springfield, failing septic systems, and cattle with direct access to streams. The inputs from the CSOs, failing septic systems, and cattle with direct access to streams were computed for each subbasin and treated as point sources from each subbasin to the main stream flowing through the subbasin. Atmospheric deposition and contributions from interflow and ground water were treated as nonpoint sources in the model. Parameter values for monthly maximum storage capacities for runoff, monthly accumulation rates for runoff, interflow concentrations, and ground-water concentrations to simulate these nonpoint sources were adjusted for each meteorologic zone that was defined in the model.

The calibrated model demonstrated fecal coliform counts (based on the maximum 30-day geometric average) in numerous HUs were greater than the chronic water-quality standard of 1,000 col/100 mL during the study period, 1999-2003.

These exceedences were observed in HUs downstream of the Springfield CSOs and at outlets immediately downstream from wastewater-treatment facilities that reported the discharge of excessive fecal coliform concentrations during selected months within the study period. The model also demonstrated that daily mean nitrate concentrations in some HUs exceeded the target concentration of $5 \mathrm{mg} / \mathrm{L}$. Although this concentration is not a water-quality standard, the Ohio EPA considers it to be a concentration above which is a reason for concern (Dale White, Ohio Environmental Protection Agency, written comm., 2005). HUs with mean nitrate concentrations greater than $5 \mathrm{mg} / \mathrm{L}$ were in predominately agricultural areas.

The calibrated model was revised to create scenarios that simulated reductions in the loads of fecal coliform and nitrate and provided a means to assess the effects of source reductions on instream fecal coliform and nitrate concentrations. The source-reduction scenarios used in the revised models were determined by the Ohio EPA. For the fecal coliform model, failing septic systems were eliminated, direct access of cattle to streams was eliminated, CSO loads were reduced by 95 percent, and monthly fecal coliform counts reported above $1,000 \mathrm{col} / 100 \mathrm{~mL}$ were reduced to $1,000 \mathrm{col} / 100 \mathrm{~mL}$ at all wastewater-treatment facilities. For the nitrate analysis, nonpoint sources were reduced throughout the Mad River Basin by 30 percent, failing septic systems were eliminated, and direct access of cattle to streams was eliminated. These source-reduction models produced major decreases in the fecal coliform and nitrate loads to the Mad River Basin. A comparison of the fecal coliform and nitrate loads exiting the outlet of the Mad River Basin showed a 73-percent reduction of fecal coliform and a 52-percent reduction of nitrate. Some HUs with mean nitrate concentrations above $5 \mathrm{mg} / \mathrm{L}$ were still indicated with the source-reduction model, although the number of HUs and the concentrations were greatly decreased. Ohio EPA may use this calibrated model to run further load-reduction scenarios before a TMDL for nitrate will be established. There were no HUs with maximum 30-day geometric means above $1,000 \mathrm{col} / 100 \mathrm{~mL}$ observed with the source-reduction scenario for fecal coliform.

\section{Acknowledgments}

The authors thank Dale White, James Connon, Mary Mahr, and Sandy Liebfritz of the Ohio EPA for their guidance and support of this project. Michael Haubner, Ohio State University Extension-Clark County, is acknowledged for providing information on local agricultural practices. Kate Flynn and Phillip Zarriello, USGS, provided guidance in calibrating the HSPF model. Paul Hummel and Jack Kittle of Aquaterra, Inc., provided instruction on the BASINS version of the HSPF model. Julie McGill of Camp Dresser \& McKee provided information on the CSOs within the City of Springfield. Michael Ekberg, Sarah Hippensteel, and Cristina Smith, Miami Conservancy District; Steven Johnson, City of Springfield; Lorre Culp, Logan County Soil and Water Conservation District; and Jennifer Ganson, Ohio State University Extension-Champaign County, provided data needed for model simulation and calibration.

\section{References Cited}

American Society of Agricultural Engineers, 1998, ASAE Standards-Standards, engineering practices, and data (45th ed.): St. Joseph, Mich. [variously paginated].

Bicknell, B.R., Imhoff, J.C., Kittle, J.L., Jr., Donigian, A.S., Jr., and Johanson, R.C., 1997, Hydrological Simulation Program-FORTRAN, User's manual for Version 11: Athens, Ga., U.S. Environmental Protection Agency, EPA/600/R97/080, $775 \mathrm{p}$.

Burton, A.G., Jr., Lavoie, D.R., and Rowland, C.D., 2001, Assessment of storm water effects in the Lower Mad River, Dayton, Ohio: Dayton, Ohio, Wright State University Institute for Environmental Quality, $18 \mathrm{p}$.

Camp Dresser \& McKee, 1997, Fecal coliform impact on Buck Creek and Mill Run during rainfall events: Submitted to Ohio Environmental Protection Agency October 21, 1997 [variously paginated]. 
Camp Dresser \& McKee, 1998, City of Springfield, Ohio CSS operational plan: Submitted to Ohio Environmental Protection Agency July 30, 1998 [variously paginated].

Camp Dresser \& McKee, 1999, City of Springfield, Ohio CSS/CSO characterization report: Submitted to Ohio Environmental Protection Agency January 29, 1999 [variously paginated].

Cohn, T.A., Caulder, D.L., Gilroy, E.J., Zynjuk, L.D., and Summers, R.M., 1992, The validity of a simple statistical model for estimating fluvial constituent loads-An empirical study involving nutrient loads entering Chesapeake Bay: Water Resources Research, v. 28, no. 9, p. 2353-2363.

Cross, W.P., and Feulner, A.J., 1964, Anomalous stream-flowground-water regime in the Mad River Basin, near Springfield, Ohio: U.S. Geological Survey Professional Paper, 475-D, p. D198-D201.

Cross, W.P., and Hedges, R.E., 1959, Flow duration of Ohio streams: Ohio Department of Natural Resources, Division of Water Bulletin 31, Report no. 3, p. 52.

Dayton Audubon Society, 2005, C.J. Brown Reservoir: Accessed March 24, 2005, at http://www.dayton.net/ Audubon/cjbrwn.htm

Debrewer, L.M., Rowe, G.L., Reutter, D.C., Moore, R.C., Hambrook, J.A., and Baker, N.T., 2000, Environmental setting and effects on water quality in the Great and Little Miami River Basins, Ohio and Indiana: U.S. Geological Survey Water-Resources Investigations Report 99-4201, $98 \mathrm{p}$.

Donigian, A.S., 2002, Watershed model calibration and validation-The HSPF experience, in Water Environment Federation National TMDL Science and Policy Meeting, November 13-16, 2002, Phoenix, Ariz.-Proceedings: 30 p. [CD-ROM]

Donigian, A.S., Imhoff, J.C., and Kittle, J.L., Jr., 2000, HSPFParm: An Interactive database of HSPF model parameters, version 1.2b1: Washington, D.C., U.S. Environmental Protection Agency Office of Science and Technology. [CDROM]

Dumouchelle, D.H., 2001, Evaluation of ground-water/surface-water relations, Chapman Creek, west-central Ohio, by means of multiple methods: U.S. Geological Survey WaterResources Investigations Report 01-4202, 13 p.

Feulner, A.J., 1960, Ground-water resources of Champaign County, Ohio: U.S. Geological Survey unnumbered OpenFile Report, 110 p., 2 pl.

Forsyth, J.L., 1956, The glacial geology of Logan and Shelby Counties: The Ohio State University, unpublished Ph.D. dissertation, $208 \mathrm{p}$.
Fuller, M.L., and Clapp, F.G., 1912, The underground water of southwestern Ohio: U.S. Geological Survey Water-Supply Paper 259, 228 p.

Harker, D.H., and Bernhagen, R.J., 1943, Water supply in Clark County: Ohio Water Supply Board, 45 p.

Harrington, S.D., 1999, Occurrence and distribution of fish species in the Great and Little Miami River Basins, Ohio and Indiana, pre-1900 to 1998: U.S. Geological Survey Water-Resources Investigations Report 99-4198, 15 p.

Harstine, L.J., 1991, Hydrologic atlas for Ohio-Average annual precipitation, temperature, streamflow, and water loss for 50-year period, 1931-1980: Ohio Department of Natural Resources, Division of Water, Water Inventory Report 28, 13 p.

Hill, F.C., 1878, Report on the geology of Champaign County: Ohio Geological Survey, v. 3, part 1, p. 491-495.

Hummel, P., Kittle, J., Jr., and Gray, M., 2001, WDMUtil (version 2.0), a tool for managing watershed modeling timeseries data-User's manual: Decatur, Ga., AQUA TERRA Consultants, contract 68-C-98-010, work assignment 2-05, accessed April 24, 2005, at http://www.epa.gov/ost/basins/ bsnsdocs.html\#wdmu

Hussein, Maged, and Schwartz, Franklin, 2003, Modeling of flow and contaminant transport in coupled stream-aquifer systems: Journal of Contaminant Hydrology, v. 65, p. 41-64.

Janosy, S.D., 2003, Trace elements and synthetic organic compounds in streambed sediment and fish tissue in the Great and Little Miami River Basins, Ohio and Indiana, 1990-98: U.S. Geological Survey Water-Resources Investigations Report 02-4305, 29 p.

Jones, Wayne, Schiefer, Mike, and Sainey, E.B., 1996, Identification of the hydrologic system and nonpoint source impacts in the Mad River watershed: Ohio Department of Natural Resources, Division of Water, Water Resources Section, Non-point Source Pollution Report 2, 306 p.

Kittle, J.L., Lumb, A.M., Hummel, P.R., Duda, P.B., and Gray, M.H., 1998, A tool for the generation and analysis of model simulation scenarios for watersheds (GenScn): U.S. Geological Survey Water-Resources Investigations Report 98-4134, $152 \mathrm{p}$.

Koltun, G.F., 1995, Determination of base-flow characteristics at selected streamflow-gaging stations on the Mad River, Ohio: U.S. Geological Survey Water-Resources Investigations Report 95-4037, 12 p.

Kristiansen, R, 1981, Sand-filter trenches for purification of septic tank effluent-II, Fate of nitrogen: Journal of Environmental Quality: v. 10, p. 358-361. 
Kuligowski, R.J., 1997, An overview of National Weather Service quantitative precipitation estimates: National Weather Service TDL Office note 97-4, 27 p.

Leverett, Frank, 1897, The water resources of Indiana and Ohio: U.S. Geological Survey 18th Annual Report, part 4, p. 419-559.

Leverett, Frank, 1902, Glacial formations and drainage features of the Erie and Ohio basins: U.S. Geological Survey Monograph 41, $802 \mathrm{p}$.

Lumb, A.M., McCammon, R.B., and Kittle, J.L., 1994, Users manual for an expert system (HSPEXP) for calibration of the Hydrological Simulation Program-Fortran: U.S. Geological Survey Water-Resources Investigations Report 94-4168, 102 p.

Mad River Steering Committee, 2003a, Water quality monitoring program underway: Mad About You (a publication of the Upper Mad River Watershed Protection Project), v. 2, no. 2 , p. 2.

Mad River Steering Committee, 2003b, At a glance-Upper Mad River Watershed: Mad About You (a publication of the Upper Mad River Watershed Protection Project), v. 2, no. 3, $4 \mathrm{p}$.

Mancl, Karen, and Slater, Brian, 2002, Suitability of Ohio soils for treating wastewater: Ohio State University Extension Bulletin 896, accessed May 15, 2005, at http://ohioline. osu.edu/b896/

Martin, J.L., and McCutcheon, S.C., 1999, Hydrodynamics and transport for water quality modeling: Boca Raton, Fla., Lewis Publishers, $794 \mathrm{p}$.

Miami Conservancy District, 2000, Observer precipitation: Water resources data, accessed March 24, 2005, at http:// www.miamiconservancy.org/Water_Resource_Monitoring/ WaterResourceApplication/ObserverPrecip/BasinAverage.

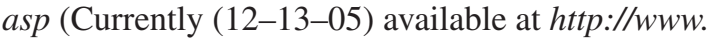
miamiconservancy.org/Water\%5FData/OBPrecip/)

Miami Conservancy District, 2002, State of the Upper Great Miami Subwatershed: Accessed February 15, 2005, http:// www.miamiconservancy.org/Water_Resource_Monitoring/ Water_Study_Reports/(Currently (12-15-05) available at http://www.miamiconservancy.org/resources/Library/ visitors/advsearch.asp)

Miami Conservancy District, 2003, 2002 water data report: Accessed February 15, 2005, at http://www. miamiconservancy.org/Water_Resource_Monitoring/Water Study_Reports/(Currently (12-15-05) available at http:// www.miamiconservancy.org/resources/Library/visitors/ advsearch.asp)
Miami Conservancy District, 2004, Assessment of groundwater quality in the Mad River Watershed in southwestern Ohio: Accessed February 15, 2005, at http://www. miamiconservancy.org/Water_Resource_Monitoring/ Water_Study_Reports/(Currently (12-15-05) available at http://www.miamiconservancy.org/resources/Library/ visitors/advsearch.asp)

Miami Conservancy District, 2005a, Huffman Dam: Accessed March 24, 2005, at http://www. miamiconservancy.org/Flood_Protection_\&_Water_ Management/Flood_Protection_System/Dams/Huffman. $h t m$ (Currently (12-13-05) available at $h t t p: / / w w w$. miamiconservancy.org/flood/dams_huffman.asp)

Miami Conservancy District, 2005b, Water resource monitoring: Accessed March 9, 2005, at http://www. miamiconservancy.org/Water_Resource_Monitoring/ Default.htm (Currently (12-13-05) available at http://www. miamiconservancy.org/water/data.asp)

Miami Conservancy District, 2005c, Who we are: Accessed March 9, 2005, at http://www.miamiconservancy.org/Who_ We_Are/Default.htm (Currently (12-13-05) available at http://www.miamiconservancy.org/about/index.asp)

Mississippi River/Gulf of Mexico Watershed Nutrient Task Force, 2001, Action plan for reducing, mitigating, and controlling hypoxia in the northern Gulf of Mexico: Accessed March 17, 2006, at http://www.epa.gov/OWOW/msbasin/ taskforcelactionplan.htm

National Agricultural Statistics Service, 2004a, 2002 Census of agriculture: Accessed December 12, 2004, at http:// www.nass.usda.gov/Census_of_Agriculture

National Agricultural Statistics Service, 2004b, Ohio statistics: Accessed November 29, 2004, at http://www.nass. usda.gov/Statistics_by_State/Ohio/index.asp

National Atmospheric Deposition Program, 2005, NADP/ NTN site list: Accessed January 14, 2005, at http://nadp. sws.uiuc.edu/nadpdatal

Norris, S.E., Cross, W.P., and Goldthwait, R.P, 1948, The water resources of Montgomery County, Ohio: Ohio Water Supply Board Bulletin 12, 83 p.

Norris, S.E., Cross, W.P., and Goldthwait, R.P, 1956, The water resources of Greene County, Ohio: Ohio Department of Natural Resources, Division of Water Bulletin 19, 52 p.

Norris, S.E., Cross, W.P., Goldthwait, R.P, and Sanderson, E.E., 1952, The water resources of Clark County, Ohio: Ohio Department of Natural Resources, Division of Water Bulletin 22, 82 p.

Norris, S.E., and Eagon, H.B., 1971, Recharge characteristics of a watercourse aquifer system at Springfield, Ohio: Ground Water, v. 9, no. 1, p. 30-41. 
Norris, S.E., and Spicer, H.C., 1958, Geological and geophysical study of the pre-glacial Teays Valley in west-central Ohio: U.S. Geological Survey Water-Supply Paper 1460-E, p. 199-231.

Ohio Department of Agriculture, 2000, Fertilizer use on corn and soybean acreage in Ohio: Accessed March 2, 2005, at http://www.nass.usda.gov/oh/bullo0/table74.htm

Ohio Environmental Protection Agency, 1986, Biological and water quality study of the Mad River and six tributaries-Logan, Champaign, Clark, Greene, and Montgomery Counties, Ohio: Columbus, Ohio, Division of Water Quality Planning and Assessment [variously paginated].

Ohio Environmental Protection Agency, 1994, Biological, sediment, and water quality study of the Lower Mad River and Hebble Creek: Ohio Environmental Protection Agency Technical Report EAS/1994-6-9, 48 p.

Ohio Environmental Protection Agency, 1998, Clean Water Act-Section 303(d) List, State of Ohio, FFY 1999-2000, Table 5: Ohio Environmental Protection Agency, Division of Surface Water, accessed on October 26, 2004, at http:// www.epa.state.oh.us/dsw/tmdl/303tab16.pdf

Ohio Environmental Protection Agency, 2002, Water body use designation index: Ohio Water Quality Standards, Ohio Administrative Code chap. 3745-1, accessed December 15, 2005, at http://www.epa.state.oh.us/dsw/rules/3745-1.html

Ohio Environmental Protection Agency, 2004, Ohio 2004 integrated water quality monitoring and assessment report: Ohio Environmental Protection Agency, Division of Surface Water, 66 p.

Ohio Environmental Protection Agency, 2005a, Biological and water quality study of the Mad River and selected tributaries, 2003: Ohio EPA Technical Report EAS/2005-5-5, 216 p.

Ohio Environmental Protection Agency, 2005b, Ohio Revised Code 3745-81-23 - Inorganic chemical monitoring requirements (section B-3), accessed on March 21, 2006, at http:// www.epa.state.oh.us/ddagw/oac.html\#374581

Ohio State University Extension, 1992, Ohio livestock manure and wastewater management guide: Bulletin 604, accessed May 5, 2005, at http://ohioline.osu.edu/b604/b604_15.html

Ohio State University Extension, 1995, Best management practices-A manure nutrient management program: Accessed December 11, 2004, at http://ohioline.osu.edu/ agf-fact/0207.html

Ohio State University Extension, 2001, Relay cropping wheat and soybeans: Accessed December 14, 2004, at http:// ohioline.osu.edu/agf-fact/0106.html
Ohio State University Extension Data Center, 2004, County profiles: Accessed December 12, 2004, at http://www. osuedc.org/profiles/

Orton, Edward, 1874, Geology of Greene County, in Report of the Geological Survey of Ohio_-Volume 2, Geology and paleontology; part 1, Geology: Columbus, Ohio, Nevins \& Myers, State Printers, p. 659-696.

Pennino, J.D., 1984, Ground water quality in the aquifer of the Upper Mad River Valley, 1940 to 1983: Ground Water Monitoring Review, v. 4, no. 3, p. 27-38.

Purdue Research Foundation, 2004, Hydrologic soil groups: Accessed May 3, 2005, at http://www.ecn.purdue.edu/ runoff/documentation/hsg.html

Quinn, M.J., and Goldthwait, R.P., 1979, Glacial geology of Champaign County, Ohio: Ohio Department of Natural Resources, Division of Geological Survey Report of Investigations 111, 17 p., 1 map with text.

Rankin, E.T., Yoder, C.O., and Mishne, D., eds., 1997, 1996 Ohio water resources inventory-Executive summary: Columbus, Ohio, Ohio Environmental Protection Agency Technical Bulletin MAS/1996-10-3, 75 p.

Reutter, D.C., 2003, Nitrogen and phosphorus in streams of the Great Miami River Basin, Ohio, 1998-2000: U.S. Geological Survey Water-Resources Investigations Report 02-4297, $67 \mathrm{p}$.

Richard, B.H., Kulibert, R.J., Wolfe, P.J., and Hudson, B., 1979, Delineation of the ancestral drainage paths of the Mad River, near Dayton, Ohio: Dayton, Ohio, Wright State University Department of Geology Technical Report Series, no. $14,71 \mathrm{p}$.

Rowe, G.L., Jr., Reutter, D.C., Runkle, D.L., Hambrook, J.A., Janosy, S.D., and Hwang, L.H., 2004, Water quality in the Great and Little Miami River Basins, Ohio and Indiana, 1999-2001: U.S. Geological Survey Circular 1229, 40 p.

Schmidt, J.J., 1982, Ground water resources of Clark County, Ohio: Ohio Department of Natural Resources, Division of Water, 1 map with text.

Schmidt, J.J., 1985, Ground water resources of Champaign County, Ohio: Ohio Department of Natural Resources, Division of Water, 1 map with text.

Schmidt, J.J., 1991, Ground water resources of Greene County, Ohio: Ohio Department of Natural Resources, Division of Water, 1 map with text.

Seaber, P.R., Kapinos, F.P., and Knapp, G.L., 1987, Hydrologic unit maps: U.S. Geological Survey Water-Supply Paper 2294, 63 p. 
Sheets, R.R., and Yost, W.P., 1994, Ground water contribution from the Silurian/Devonian carbonate aquifer to the Mad River Valley, southwestern Ohio: Ohio Journal of Science, v. 94 , no. 5 , p. 138-146.

Shindel, H.L., Mangus, J.P., and Trimble, L.E., 2000, Water resources data, Ohio, water year 1999-Volume 2, St. Lawrence River Basin and statewide project data: U.S. Geological Survey Water-Data Report OH-99-2, p. 332-338.

Shindel, H.L., Mangus, J.P., and Trimble, L.E., 2001, Water resources data, Ohio, water year 2000-Volume 2, St. Lawrence River Basin and statewide project data: U.S. Geological Survey Water-Data Report OH-00-2, p. 169-178.

Shindel, H.L., Mangus, J.P., and Trimble, L.E., 2002, Water resources data, Ohio, water year 2001-Volume 2, St. Lawrence River Basin and statewide project data: U.S. Geological Survey Water-Data Report OH-01-2, p. 226-232.

Shindel, H.L., Mangus, J.P., and Frum, S.R., 2003, Water resources data, Ohio, water year 2002-Volume 2, St. Lawrence River Basin and statewide project data: U.S. Geological Survey Water-Data Report OH-02-2, p. 267-276.

Shindel, H.L., Mangus, J.P., and Frum, S.R., 2004, Water resources data, Ohio, water year 2003-Volume 2, St. Lawrence River Basin and statewide project data: U.S. Geological Survey Water-Data Report OH-03-2, p. 147-154.

Shindel, H.L., Mangus, J.P., and Frum, S.R., 2005, Water resources data, Ohio, water year 2004-Volume 2, St. Lawrence River Basin and statewide project data: U.S. Geological Survey Water-Data Report OH-04-2, 312 p.

Smindak, K.M., 1992, Aquifer properties and infiltration conditions at a proposed well field along the Mad River near Medway, Ohio: Dayton, Ohio, Wright State University, Master's thesis, $100 \mathrm{p}$.

Soller, D.R., 1993, Maps showing the thickness and character of Quaternary sediments in the glaciated United States east of the Rocky Mountains-Northeastern states, the Great Lakes, and parts of southern Ontario and the Atlantic offshore area (east of $80^{\circ} 31^{\prime}$ 'west longitude): U.S. Geological Survey Miscellaneous Investigations Series Map I-1970-A, scale $1: 1,000,000$.

Soller, D.R., 1998, Maps showing the thickness and character of Quaternary sediments in the glaciated United States east of the Rocky Mountains-Northern Great Lake states and central Mississippi Valley states and southern Ontario ( $80^{\circ} 31^{\prime}$ to $93^{\circ}$ west longitude): U.S. Geological Survey Miscellaneous Investigations Series Map I-1970-B, scale $1: 1,000,000$.
Speiker, A.M., and Durrell, R.H., 1961, A guide to the geohydrology of the Mill Creek and Mad River Valleys OhioField trip 6 in Geological Society of America Guidebook for field trips, Cincinnati meeting, 1961, p. 215-251.

Stoeckel, D.M, and Covert, S.A., 2002, Water quality of the Mahoning River and selected tributaries in Youngstown, Ohio: U.S. Geological Survey Water-Resources Investigations Report 02-4122, 45 p.

U.S. Army Corps of Engineers, 2005, C.J. Brown Dam and Reservoir: Louisville District, accessed March 24, 2005, at http://www.lrl.usace.army.mil/cjbl/

U.S. Department of Agriculture, 1991a, State Soil Geographic (STATSGO) data base for Ohio [machine-readable files]: Ft. Worth, Tex., National Resources Conservation Service, National Soil Survey Center. (Currently (12-15-05) available online at http://www.ncgc.nrcs.usda.gov/products/ datasets/statsgo/index.html)

U.S. Department of Agriculture, 1991b, 14-digit hydrologic unit areas for Ohio [machine-readable files]: Columbus, Ohio, Natural Resources Conservation Service. (Currently (12-15-05) available online at http://www.oh.nrcs.usda. gov/technical/14-digit/download.html)

U.S. Department of Agriculture, 2005, National soil survey handbook, title 430-VI; Soil properties and qualities (Part 618): National Resources Conservation Service, accessed December 15, 2005, at http://soils.usda.gov/technical/ handbook/

U.S. Environmental Protection Agency, 2000a, National water quality inventory-1998 report to Congress: U.S. Environmental Protection Agency Report EPA-841-F-00-006, accessed December 15, 2005, at http://www.epa.gov/305b/ 98report।

U.S. Environmental Protection Agency, 2000b, EPA Bacterial Indicator Tool user's guide: Washington D.C., U.S. Environmental Protection Agency Report EPA-823-B-01-003, $17 \mathrm{p}$.

U.S. Environmental Protection Agency, 2003, National Pollutant Discharge Elimination System (NPDES): Accessed January 23, 2005, at http://cfpub.epa.gov/npdes

U.S. Environmental Protection Agency, 2004a, Clean Air Status and Trends Network (CASTNET): Accessed January 15, 2005, at http://www.epa.gov/castnet

U.S. Environmental Protection Agency, 2004b, Report to Congress-Impact and control of CSOs and SSOs: Washington, D.C., U.S. Environmental Protection Agency Report EPA 833-R-04-001 [variously paginated], accessed June 24, 2005, at http://www.epa.gov/npdes/pubs/csossoRTC2004_ chapter04.pdf 
U.S. Geological Survey, 1992, National land cover dataset 1992 (NLCD 1992): Accessed December 8, 2005, at http:// landcover.usgs.gov/natllandcover.asp

U.S. Geological Survey, 2000, Great and Little Miami River Basins ground-water quality data, 2000 water year: Accessed August 24, 2003, at URL http://oh.water.usgs. gov/maim/WYOO_GWQW_AgLUS.pdf

U.S. Geological Survey, 2003, NLCD land cover class definitions: Accessed September 6, 2005, at http://landcover.usgs. gov/classes.asp\#develop

U.S. Geological Survey, 2005a, National Elevation Dataset (NED): Accessed December 23, 2005, at http://seamless. usgs.gov/website/seamless/products/larc.asp

U.S. Geological Survey, 2005b, National Hydrography Dataset (NHD): Accessed December 23, 2005, at http://nhd.usgs. gov/data.html

U.S. Geological Survey, 2005c, NWISWeb data for Ohio: Accessed November 9, 2005, at http://waterdata.usgs. gov/oh/nwis

Yost, W.P., 1995, Data on ground-water levels and groundwater/surface-water relations in the Great Miami River and Little Miami River Valleys, southwestern Ohio: U.S. Geological Survey Open-File Report 95-357, 57 p.

Zarriello, P.J., and Ries K.G., 2000, A precipitation-runoff model for analysis of the effects of water withdrawals on streamflow, Ipswich River Basin, Massachusetts: U.S. Geological Survey Water-Resources Investigation Report 00-4029, $30 \mathrm{p}$. 


\section{Appendixes}

\section{Explanation of the PERLAND codes used in Appendixes 2 through 4}

The term "PERLAND" is used in the following tables to describe the permeable land segments used in the models. The PERLAND consists of a three-digit code. The first digit of the PERLAND code represents the model-segmentation number, and the last two digits represent the land-use classification. The following numbers are used for land-use classification:

01 Water

02 Low-intensity residential

03 High-intensity residential

04 Commercial/Industrial

05 Urban or built-up land

06 Forest

07 Pasture

08 Agricultural land 
Appendix 1. Percentage of each 14-digit hydrologic unit with a given land-cover classification.

[Land-cover data obtained from U.S. Geological Survey, 1992. Some categories were reclassified for the model, as indicated in table 3. Model subbasins are shown on figure 7. HU, hydrologic unit]

\begin{tabular}{|c|c|c|c|c|c|c|c|c|c|}
\hline \multirow[b]{2}{*}{$\begin{array}{l}\text { 14-digit HU, } \\
\text { (05080001-) }\end{array}$} & \multirow[b]{2}{*}{$\begin{array}{c}\text { Model } \\
\text { subbasin(s) }\end{array}$} & \multicolumn{6}{|c|}{ Model land-cover classification } & \multirow[b]{2}{*}{$\begin{array}{l}\text { Agricultural } \\
\text { land }\end{array}$} & \multirow[b]{2}{*}{$\begin{array}{c}\text { Urban or } \\
\text { built-up } \\
\text { land }\end{array}$} \\
\hline & & Water & $\begin{array}{c}\text { Low- } \\
\text { intensity } \\
\text { residential }\end{array}$ & $\begin{array}{c}\text { High- } \\
\text { intensity } \\
\text { residential }\end{array}$ & $\begin{array}{c}\text { Commercial/ } \\
\text { industrial }\end{array}$ & Forest & Pasture & & \\
\hline $150-020$ & 31 & 0.05 & 0.98 & 0.05 & 0.06 & 33.77 & 19.20 & 45.30 & 0.59 \\
\hline $150-030$ & 27 & 0.08 & 0.02 & 0.01 & 0.00 & 25.24 & 20.13 & 54.38 & 0.15 \\
\hline $150-060$ & 3 & 0.07 & 0.19 & 0.01 & 0.09 & 10.47 & 22.58 & 66.59 & 0.00 \\
\hline $160-010$ & $8,32,42$ & 3.31 & 0.32 & 0.10 & 0.39 & 9.57 & 11.96 & 74.30 & 0.05 \\
\hline $160-020$ & 4 & 0.08 & 0.00 & 0.00 & 0.00 & 9.67 & 9.49 & 80.76 & 0.00 \\
\hline $160-030$ & 5,51 & 0.52 & 7.99 & 1.46 & 2.41 & 8.17 & 15.06 & 57.49 & 6.89 \\
\hline $160-040$ & 7,41 & 0.17 & 1.26 & 0.20 & 0.11 & 19.64 & 18.38 & 60.04 & 0.20 \\
\hline $160-050$ & 6 & 0.07 & 0.13 & 0.03 & 0.10 & 7.10 & 11.77 & 80.81 & 0.00 \\
\hline $170-020$ & 38 & 0.18 & 0.27 & 0.03 & 0.15 & 15.49 & 21.78 & 62.11 & 0.00 \\
\hline $170-030$ & 13,37 & 13.03 & 1.76 & 0.07 & 0.51 & 8.98 & 26.38 & 48.55 & 0.72 \\
\hline $170-040$ & 14,36 & 0.49 & 1.40 & 0.20 & 0.82 & 10.04 & 21.60 & 64.19 & 1.25 \\
\hline $170-050$ & 15 & 1.27 & 0.43 & 0.08 & 0.40 & 8.06 & 26.34 & 63.42 & 0.00 \\
\hline $170-060$ & $28,35,47,48$ & 0.31 & 35.06 & 8.44 & 16.78 & 11.09 & 3.26 & 9.73 & 15.35 \\
\hline $180-010$ & 17,33 & 1.25 & 9.54 & 0.75 & 5.21 & 22.45 & 17.31 & 37.99 & 5.49 \\
\hline $180-020$ & 12 & 0.16 & 8.17 & 0.53 & 3.46 & 17.72 & 20.39 & 47.12 & 2.46 \\
\hline $180-030$ & $29,34,49$ & 2.67 & 5.79 & 0.67 & 3.37 & 16.94 & 23.64 & 45.80 & 1.12 \\
\hline $180-040$ & 19,52 & 0.08 & 15.44 & 2.34 & 6.37 & 10.01 & 15.87 & 47.21 & 2.68 \\
\hline $180-050$ & 18 & 0.11 & 6.39 & 0.93 & 1.62 & 8.75 & 21.84 & 57.80 & 2.55 \\
\hline $180-060$ & 20 & 0.06 & 1.63 & 0.11 & 0.16 & 8.22 & 15.80 & 73.76 & 0.26 \\
\hline
\end{tabular}


Appendix 2. Values of selected parameters used in calibrated model to simulate streamflow.

Table 2-1. Monthly lower zone evapotranspiration (MON-LZETPARM) [PERLAND, permeable land segment]

\begin{tabular}{|c|c|c|c|c|c|c|c|c|c|c|c|c|}
\hline PERLAND & Jan & Feb & Mar & Apr & May & Jun & Jul & Aug & Sep & Oct & Nov & Dec \\
\hline $101-105$ & 0.2 & 0.2 & 0.2 & 0.2 & 0.2 & 0.2 & 0.2 & 0.2 & 0.2 & 0.2 & 0.2 & 0.2 \\
\hline 106 & 0.2 & 0.2 & 0.3 & 0.3 & 0.5 & 0.7 & 0.7 & 0.7 & 0.5 & 0.3 & 0.2 & 0.2 \\
\hline 107 & 0.2 & 0.2 & 0.3 & 0.3 & 0.4 & 0.5 & 0.5 & 0.5 & 0.4 & 0.3 & 0.2 & 0.2 \\
\hline 108 & 0.2 & 0.2 & 0.2 & 0.2 & 0.3 & 0.5 & 0.7 & 0.7 & 0.6 & 0.4 & 0.2 & 0.2 \\
\hline $201-205$ & 0.2 & 0.2 & 0.2 & 0.2 & 0.2 & 0.2 & 0.2 & 0.2 & 0.2 & 0.2 & 0.2 & 0.2 \\
\hline 206 & 0.2 & 0.2 & 0.3 & 0.3 & 0.5 & 0.7 & 0.7 & 0.7 & 0.5 & 0.3 & 0.2 & 0.2 \\
\hline 207 & 0.2 & 0.2 & 0.3 & 0.3 & 0.4 & 0.5 & 0.5 & 0.5 & 0.4 & 0.3 & 0.2 & 0.2 \\
\hline 208 & 0.2 & 0.2 & 0.2 & 0.2 & 0.3 & 0.5 & 0.7 & 0.7 & 0.6 & 0.4 & 0.2 & 0.2 \\
\hline $301-305$ & 0.2 & 0.2 & 0.2 & 0.2 & 0.2 & 0.2 & 0.2 & 0.2 & 0.2 & 0.2 & 0.2 & 0.2 \\
\hline 306 & 0.2 & 0.2 & 0.3 & 0.3 & 0.5 & 0.7 & 0.7 & 0.7 & 0.5 & 0.3 & 0.2 & 0.2 \\
\hline 307 & 0.2 & 0.2 & 0.3 & 0.3 & 0.4 & 0.5 & 0.5 & 0.5 & 0.4 & 0.3 & 0.2 & 0.2 \\
\hline 308 & 0.2 & 0.2 & 0.2 & 0.2 & 0.3 & 0.5 & 0.7 & 0.7 & 0.6 & 0.4 & 0.2 & 0.2 \\
\hline $401-405$ & 0.4 & 0.4 & 0.4 & 0.4 & 0.4 & 0.4 & 0.4 & 0.4 & 0.4 & 0.4 & 0.4 & 0.4 \\
\hline 406 & 0.4 & 0.4 & 0.6 & 0.6 & 1 & 1.4 & 1.4 & 1.4 & 1 & 0.6 & 0.4 & 0.4 \\
\hline 407 & 0.4 & 0.4 & 0.6 & 0.6 & 0.8 & 1 & 1 & 1 & 0.8 & 0.6 & 0.4 & 0.4 \\
\hline 408 & 0.4 & 0.4 & 0.4 & 0.4 & 0.6 & 1 & 1.4 & 1.4 & 1.2 & 0.8 & 0.4 & 0.4 \\
\hline $501-505$ & 0.2 & 0.2 & 0.2 & 0.2 & 0.2 & 0.2 & 0.2 & 0.2 & 0.2 & 0.2 & 0.2 & 0.2 \\
\hline 506 & 0.2 & 0.2 & 0.3 & 0.3 & 0.5 & 0.7 & 0.7 & 0.7 & 0.5 & 0.3 & 0.2 & 0.2 \\
\hline 507 & 0.2 & 0.2 & 0.3 & 0.3 & 0.4 & 0.5 & 0.5 & 0.5 & 0.4 & 0.3 & 0.2 & 0.2 \\
\hline 508 & 0.2 & 0.2 & 0.2 & 0.2 & 0.3 & 0.5 & 0.7 & 0.7 & 0.6 & 0.4 & 0.2 & 0.2 \\
\hline $601-605$ & 0.2 & 0.2 & 0.2 & 0.2 & 0.2 & 0.2 & 0.2 & 0.2 & 0.2 & 0.2 & 0.2 & 0.2 \\
\hline 606 & 0.2 & 0.2 & 0.3 & 0.3 & 0.5 & 0.7 & 0.7 & 0.7 & 0.5 & 0.3 & 0.2 & 0.2 \\
\hline 607 & 0.2 & 0.2 & 0.3 & 0.3 & 0.4 & 0.5 & 0.5 & 0.5 & 0.4 & 0.3 & 0.2 & 0.2 \\
\hline 608 & 0.2 & 0.2 & 0.2 & 0.2 & 0.3 & 0.5 & 0.7 & 0.7 & 0.6 & 0.4 & 0.2 & 0.2 \\
\hline 701-704 & 0.2 & 0.2 & 0.2 & 0.2 & 0.2 & 0.2 & 0.2 & 0.2 & 0.2 & 0.2 & 0.2 & 0.2 \\
\hline 706 & 0.2 & 0.2 & 0.3 & 0.3 & 0.5 & 0.7 & 0.7 & 0.7 & 0.5 & 0.3 & 0.2 & 0.2 \\
\hline 707 & 0.2 & 0.2 & 0.3 & 0.3 & 0.4 & 0.5 & 0.5 & 0.5 & 0.4 & 0.3 & 0.2 & 0.2 \\
\hline 708 & 0.2 & 0.2 & 0.2 & 0.2 & 0.3 & 0.5 & 0.7 & 0.7 & 0.6 & 0.4 & 0.2 & 0.2 \\
\hline $801-804$ & 0.2 & 0.2 & 0.2 & 0.2 & 0.2 & 0.2 & 0.2 & 0.2 & 0.2 & 0.2 & 0.2 & 0.2 \\
\hline 806 & 0.2 & 0.2 & 0.3 & 0.3 & 0.5 & 0.7 & 0.7 & 0.7 & 0.5 & 0.3 & 0.2 & 0.2 \\
\hline 807 & 0.2 & 0.2 & 0.3 & 0.3 & 0.4 & 0.5 & 0.5 & 0.5 & 0.4 & 0.3 & 0.2 & 0.2 \\
\hline 808 & 0.2 & 0.2 & 0.2 & 0.2 & 0.3 & 0.5 & 0.7 & 0.7 & 0.6 & 0.4 & 0.2 & 0.2 \\
\hline $901-903$ & 0.2 & 0.2 & 0.2 & 0.2 & 0.2 & 0.2 & 0.2 & 0.2 & 0.2 & 0.2 & 0.2 & 0.2 \\
\hline 906 & 0.2 & 0.2 & 0.3 & 0.3 & 0.5 & 0.7 & 0.7 & 0.7 & 0.5 & 0.3 & 0.2 & 0.2 \\
\hline 907 & 0.2 & 0.2 & 0.3 & 0.3 & 0.4 & 0.5 & 0.5 & 0.5 & 0.4 & 0.3 & 0.2 & 0.2 \\
\hline 908 & 0.2 & 0.2 & 0.2 & 0.2 & 0.3 & 0.5 & 0.7 & 0.7 & 0.6 & 0.4 & 0.2 & 0.2 \\
\hline
\end{tabular}


Appendix 2. Values of selected parameters used in calibrated model to simulate streamflow. —Continued

Table 2-2. Monthly interception storage capacity (MON-INTERCEP), in inches

\begin{tabular}{|c|c|c|c|c|c|c|c|c|c|c|c|c|}
\hline PERLAND & Jan & Feb & Mar & Apr & May & Jun & Jul & Aug & Sep & Oct & Nov & Dec \\
\hline 101 & 0.02 & 0.02 & 0.02 & 0.02 & 0.02 & 0.02 & 0.02 & 0.02 & 0.02 & 0.02 & 0.02 & 0.02 \\
\hline 102 & 0.092 & 0.092 & 0.092 & 0.093 & 0.095 & 0.096 & 0.096 & 0.096 & 0.096 & 0.094 & 0.092 & 0.092 \\
\hline 104 & 0.092 & 0.092 & 0.092 & 0.093 & 0.093 & 0.094 & 0.094 & 0.094 & 0.094 & 0.094 & 0.092 & 0.092 \\
\hline 105 & 0.092 & 0.092 & 0.092 & 0.093 & 0.095 & 0.096 & 0.096 & 0.096 & 0.096 & 0.094 & 0.092 & 0.092 \\
\hline 106 & 0.06 & 0.06 & 0.06 & 0.08 & 0.12 & 0.16 & 0.16 & 0.16 & 0.16 & 0.16 & 0.07 & 0.06 \\
\hline 108 & 0.02 & 0.02 & 0.02 & 0.04 & 0.08 & 0.1 & 0.143 & 0.143 & 0.143 & 0.08 & 0.02 & 0.02 \\
\hline 201 & 0.02 & 0.02 & 0.02 & 0.02 & 0.02 & 0.02 & 0.02 & 0.02 & 0.02 & 0.02 & 0.02 & 0.02 \\
\hline 202 & 0.092 & 0.092 & 0.092 & 0.093 & 0.095 & 0.096 & 0.096 & 0.096 & 0.096 & 0.094 & 0.092 & 0.092 \\
\hline 203 & 0.092 & 0.092 & 0.092 & 0.093 & 0.094 & 0.095 & 0.094 & 0.094 & 0.094 & 0.094 & 0.092 & 0.092 \\
\hline 204 & 0.092 & 0.092 & 0.092 & 0.093 & 0.093 & 0.094 & 0.094 & 0.094 & 0.094 & 0.094 & 0.092 & 0.092 \\
\hline 208 & 0.02 & 0.02 & 0.02 & 0.04 & 0.08 & 0.1 & 0.143 & 0.143 & 0.143 & 0.08 & 0.02 & 0.02 \\
\hline 301 & 0.02 & 0.02 & 0.02 & 0.02 & 0.02 & 0.02 & 0.02 & 0.02 & 0.02 & 0.02 & 0.02 & 0.02 \\
\hline 302 & 0.092 & 0.092 & 0.092 & 0.093 & 0.095 & 0.096 & 0.096 & 0.096 & 0.096 & 0.094 & 0.092 & 0.092 \\
\hline 303 & 0.092 & 0.092 & 0.092 & 0.093 & 0.094 & 0.095 & 0.094 & 0.094 & 0.094 & 0.094 & 0.092 & 0.092 \\
\hline 304 & 0.092 & 0.092 & 0.092 & 0.093 & 0.093 & 0.094 & 0.094 & 0.094 & 0.094 & 0.094 & 0.092 & 0.092 \\
\hline 305 & 0.092 & 0.092 & 0.092 & 0.093 & 0.095 & 0.096 & 0.096 & 0.096 & 0.096 & 0.094 & 0.092 & 0.092 \\
\hline 306 & 0.06 & 0.06 & 0.06 & 0.08 & 0.12 & 0.16 & 0.16 & 0.16 & 0.16 & 0.1 & 0.07 & 0.06 \\
\hline 307 & 0.06 & 0.06 & 0.06 & 0.068 & 0.078 & 0.088 & 0.098 & 0.098 & 0.098 & 0.078 & 0.06 & 0.06 \\
\hline 308 & 0.02 & 0.02 & 0.02 & 0.04 & 0.08 & 0.1 & 0.143 & 0.143 & 0.143 & 0.08 & 0.02 & 0.02 \\
\hline
\end{tabular}


Appendix 2. Values of selected parameters used in calibrated model to simulate streamflow. —Continued

Table 2-2. Monthly interception storage capacity (MON-INTERCEP), in inches.-Continued

\begin{tabular}{|c|c|c|c|c|c|c|c|c|c|c|c|c|}
\hline PERLAND & Jan & Feb & Mar & Apr & May & Jun & Jul & Aug & Sep & Oct & Nov & Dec \\
\hline 401 & 0.02 & 0.02 & 0.02 & 0.02 & 0.02 & 0.02 & 0.02 & 0.02 & 0.02 & 0.02 & 0.02 & 0.02 \\
\hline 402 & 0.092 & 0.092 & 0.092 & 0.093 & 0.095 & 0.096 & 0.096 & 0.096 & 0.096 & 0.094 & 0.092 & 0.092 \\
\hline 404 & 0.092 & 0.092 & 0.092 & 0.093 & 0.093 & 0.094 & 0.094 & 0.094 & 0.094 & 0.094 & 0.092 & 0.092 \\
\hline 405 & 0.092 & 0.092 & 0.092 & 0.093 & 0.095 & 0.096 & 0.096 & 0.096 & 0.096 & 0.094 & 0.092 & 0.092 \\
\hline 406 & 0.06 & 0.06 & 0.06 & 0.08 & 0.12 & 0.16 & 0.16 & 0.16 & 0.16 & 0.1 & 0.07 & 0.06 \\
\hline 408 & 0.02 & 0.02 & 0.02 & 0.04 & 0.08 & 0.1 & 0.143 & 0.143 & 0.143 & 0.08 & 0.02 & 0.02 \\
\hline 501 & 0.02 & 0.02 & 0.02 & 0.02 & 0.02 & 0.02 & 0.02 & 0.02 & 0.02 & 0.02 & 0.02 & 0.02 \\
\hline 502 & 0.092 & 0.092 & 0.092 & 0.093 & 0.095 & 0.096 & 0.096 & 0.096 & 0.096 & 0.094 & 0.092 & 0.092 \\
\hline 503 & 0.092 & 0.092 & 0.092 & 0.093 & 0.094 & 0.095 & 0.094 & 0.094 & 0.094 & 0.094 & 0.092 & 0.092 \\
\hline 504 & 0.092 & 0.092 & 0.092 & 0.093 & 0.093 & 0.094 & 0.094 & 0.094 & 0.094 & 0.094 & 0.092 & 0.092 \\
\hline 508 & 0.02 & 0.02 & 0.02 & 0.04 & 0.08 & 0.1 & 0.143 & 0.143 & 0.143 & 0.08 & 0.02 & 0.02 \\
\hline 601 & 0.02 & 0.02 & 0.02 & 0.02 & 0.02 & 0.02 & 0.02 & 0.02 & 0.02 & 0.02 & 0.02 & 0.02 \\
\hline 602 & 0.092 & 0.092 & 0.092 & 0.093 & 0.095 & 0.096 & 0.096 & 0.096 & 0.096 & 0.094 & 0.092 & 0.092 \\
\hline 603 & 0.092 & 0.092 & 0.092 & 0.093 & 0.094 & 0.095 & 0.094 & 0.094 & 0.094 & 0.094 & 0.092 & 0.092 \\
\hline 604 & 0.092 & 0.092 & 0.092 & 0.093 & 0.093 & 0.094 & 0.094 & 0.094 & 0.094 & 0.094 & 0.092 & 0.092 \\
\hline 605 & 0.092 & 0.092 & 0.092 & 0.093 & 0.095 & 0.096 & 0.096 & 0.096 & 0.096 & 0.094 & 0.092 & 0.092 \\
\hline 606 & 0.06 & 0.06 & 0.06 & 0.08 & 0.12 & 0.16 & 0.16 & 0.16 & 0.16 & 0.1 & 0.07 & 0.06 \\
\hline 607 & 0.06 & 0.06 & 0.06 & 0.068 & 0.078 & 0.088 & 0.098 & 0.098 & 0.098 & 0.078 & 0.06 & 0.06 \\
\hline 608 & 0.02 & 0.02 & 0.02 & 0.04 & 0.08 & 0.1 & 0.143 & 0.143 & 0.143 & 0.08 & 0.02 & 0.02 \\
\hline
\end{tabular}




\section{Simulation of Fecal Coliform and Nitrate in the Mad River Basin, Ohio}

Appendix 2. Values of selected parameters used in calibrated model to simulate streamflow. —Continued

Table 2-2. Monthly interception storage capacity (MON-INTERCEP), in inches.-Continued

\begin{tabular}{|c|c|c|c|c|c|c|c|c|c|c|c|c|}
\hline PERLAND & Jan & Feb & Mar & Apr & May & Jun & Jul & Aug & Sep & Oct & Nov & Dec \\
\hline 701 & 0.02 & 0.02 & 0.02 & 0.02 & 0.02 & 0.02 & 0.02 & 0.02 & 0.02 & 0.02 & 0.02 & 0.02 \\
\hline 702 & 0.092 & 0.092 & 0.092 & 0.093 & 0.095 & 0.096 & 0.096 & 0.096 & 0.096 & 0.094 & 0.092 & 0.092 \\
\hline 704 & 0.092 & 0.092 & 0.092 & 0.093 & 0.093 & 0.094 & 0.094 & 0.094 & 0.094 & 0.094 & 0.092 & 0.092 \\
\hline 706 & 0.06 & 0.06 & 0.06 & 0.08 & 0.12 & 0.16 & 0.16 & 0.16 & 0.16 & 0.1 & 0.07 & 0.06 \\
\hline 707 & 0.06 & 0.06 & 0.06 & 0.068 & 0.078 & 0.088 & 0.098 & 0.098 & 0.098 & 0.078 & 0.06 & 0.06 \\
\hline 801 & 0.02 & 0.02 & 0.02 & 0.02 & 0.02 & 0.02 & 0.02 & 0.02 & 0.02 & 0.02 & 0.02 & 0.02 \\
\hline 802 & 0.092 & 0.092 & 0.092 & 0.093 & 0.095 & 0.096 & 0.096 & 0.096 & 0.096 & 0.094 & 0.092 & 0.092 \\
\hline 803 & 0.092 & 0.092 & 0.092 & 0.093 & 0.094 & 0.095 & 0.094 & 0.094 & 0.094 & 0.094 & 0.092 & 0.092 \\
\hline 804 & 0.092 & 0.092 & 0.092 & 0.093 & 0.093 & 0.094 & 0.094 & 0.094 & 0.094 & 0.094 & 0.092 & 0.092 \\
\hline 806 & 0.06 & 0.06 & 0.06 & 0.08 & 0.12 & 0.16 & 0.16 & 0.16 & 0.16 & 0.1 & 0.07 & 0.06 \\
\hline 902 & 0.092 & 0.092 & 0.092 & 0.093 & 0.095 & 0.096 & 0.096 & 0.096 & 0.096 & 0.094 & 0.092 & 0.092 \\
\hline 903 & 0.092 & 0.092 & 0.092 & 0.093 & 0.094 & 0.095 & 0.094 & 0.094 & 0.094 & 0.094 & 0.092 & 0.092 \\
\hline 906 & 0.06 & 0.06 & 0.06 & 0.08 & 0.12 & 0.16 & 0.16 & 0.16 & 0.16 & 0.1 & 0.07 & 0.06 \\
\hline 907 & 0.06 & 0.06 & 0.06 & 0.068 & 0.078 & 0.088 & 0.098 & 0.098 & 0.098 & 0.078 & 0.06 & 0.06 \\
\hline 908 & 0.02 & 0.02 & 0.02 & 0.04 & 0.08 & 0.1 & 0.143 & 0.143 & 0.143 & 0.08 & 0.02 & 0.02 \\
\hline
\end{tabular}


Appendix 2. Values of selected parameters used in calibrated model to simulate streamflow. —Continued

Table 2-3. Additional parameter values used to simulate streamflow.

[INFILT, infiltration capacity of the soil (inches per hour); INTFW, interflow coefficient; KVARY, ground-water recession flow (per inches); LSUR, length of the overland flow plane (feet); LZETP, lower zone evapotranspiration parameter (inches); LZSN, lower zone nominal storage (inches); UZSN, upper zone nominal storage (inches)]

\begin{tabular}{|c|c|c|c|c|c|c|c|c|}
\hline PERLAND & AGWRC & INFILT & INTFW & KVARY & LSUR & LZETP & LZSN & UZSN \\
\hline 101 & 0.999 & 0.006 & 3 & 4 & 350 & 0.1 & 3.6 & 0.281 \\
\hline 102 & 0.999 & 0.024 & 1.5 & 4 & 350 & 0.3 & 3.9 & 0.844 \\
\hline 103 & 0.999 & 0.024 & 2 & 4 & 350 & 0.25 & 3.9 & 0.703 \\
\hline 104 & 0.999 & 0.015 & 2 & 4 & 350 & 0.2 & 3.9 & 0.563 \\
\hline 105 & 0.999 & 0.018 & 2 & 4 & 350 & 0.3 & 3.6 & 0.844 \\
\hline 106 & 0.999 & 0.06 & 1.5 & 4 & 350 & 0.7 & 3.9 & 1.969 \\
\hline 107 & 0.999 & 0.06 & 2 & 4 & 350 & 0.5 & 3.6 & 1.406 \\
\hline 108 & 0.999 & 0.024 & 2.2 & 4 & 350 & 0.6 & 3.6 & 1.688 \\
\hline 201 & 0.999 & 0.01 & 3 & 2 & 350 & 0.1 & 3 & 0.281 \\
\hline 202 & 0.999 & 0.04 & 1.5 & 2 & 350 & 0.3 & 3.25 & 0.844 \\
\hline 203 & 0.999 & 0.04 & 2 & 2 & 350 & 0.25 & 3.25 & 0.703 \\
\hline 204 & 0.999 & 0.025 & 2 & 2 & 350 & 0.2 & 3.25 & 0.563 \\
\hline 205 & 0.999 & 0.03 & 2 & 2 & 350 & 0.3 & 3 & 0.844 \\
\hline 206 & 0.999 & 0.1 & 1.5 & 2 & 350 & 0.7 & 3.25 & 1.969 \\
\hline 207 & 0.999 & 0.1 & 2 & 2 & 350 & 0.5 & 3 & 1.406 \\
\hline 208 & 0.999 & 0.04 & 2.2 & 2 & 350 & 0.6 & 3 & 1.688 \\
\hline 301 & 0.999 & 0.01 & 3 & 2 & 350 & 0.1 & 3 & 0.281 \\
\hline 302 & 0.999 & 0.04 & 1.5 & 2 & 350 & 0.3 & 3.25 & 0.844 \\
\hline 303 & 0.999 & 0.04 & 2 & 2 & 350 & 0.25 & 3.25 & 0.703 \\
\hline 304 & 0.999 & 0.025 & 2 & 2 & 350 & 0.2 & 3.25 & 0.563 \\
\hline 305 & 0.999 & 0.03 & 2 & 2 & 350 & 0.3 & 3 & 0.844 \\
\hline 306 & 0.999 & 0.1 & 1.5 & 2 & 350 & 0.7 & 3.25 & 1.969 \\
\hline 307 & 0.999 & 0.1 & 2 & 2 & 350 & 0.5 & 3 & 1.8 \\
\hline 308 & 0.999 & 0.04 & 2.2 & 2 & 350 & 0.6 & 3 & 1.8 \\
\hline 401 & 0.999 & 0.004 & 6 & 5 & 350 & 0.1 & 5.6 & 0.281 \\
\hline 402 & 0.999 & 0.002 & 5 & 5 & 350 & 0.3 & 5.9 & 0.844 \\
\hline 403 & 0.999 & 0.008 & 5.5 & 5 & 350 & 0.25 & 5.9 & 0.703 \\
\hline 404 & 0.999 & 0.008 & 5.5 & 5 & 350 & 0.2 & 5.9 & 0.563 \\
\hline 405 & 0.999 & 0.005 & 3 & 5 & 350 & 0.3 & 5.6 & 0.844 \\
\hline 406 & 0.999 & 0.007 & 2.5 & 5 & 350 & 0.7 & 3.9 & 1.969 \\
\hline 407 & 0.999 & 0.022 & 6.8 & 5 & 350 & 0.5 & 5.6 & 1.8 \\
\hline 408 & 0.999 & 0.022 & 6.9 & 5 & 350 & 0.6 & 5.6 & 1.8 \\
\hline
\end{tabular}


Appendix 2. Values of selected parameters used in calibrated model to simulate streamflow. —Continued

\begin{tabular}{|c|c|c|c|c|c|c|c|c|}
\hline PERLAND & AGWRC & INFILT & INTFW & KVARY & LSUR & LZETP & LZSN & UZSN \\
\hline 501 & 0.999 & 0.008 & 3 & 2 & 350 & 0.1 & 3 & 0.2813 \\
\hline 502 & 0.999 & 0.04 & 1.5 & 2 & 350 & 0.3 & 3.25 & 0.8438 \\
\hline 503 & 0.999 & 0.04 & 2 & 2 & 350 & 0.25 & 3.25 & 0.7031 \\
\hline 504 & 0.999 & 0.025 & 2 & 2 & 350 & 0.2 & 3.25 & 0.5625 \\
\hline 505 & 0.999 & 0.03 & 2 & 2 & 350 & 0.3 & 3 & 0.8438 \\
\hline 506 & 0.999 & 0.1 & 1.5 & 2 & 350 & 0.7 & 3.25 & 1.9688 \\
\hline 507 & 0.999 & 0.1 & 2 & 2 & 350 & 0.5 & 3 & 1.4063 \\
\hline 508 & 0.999 & 0.04 & 2.2 & 2 & 350 & 0.6 & 3 & 1.6875 \\
\hline 601 & 0.999 & 0.006 & 3 & 2 & 350 & 0.1 & 3.6 & 0.281 \\
\hline 602 & 0.999 & 0.024 & 1.5 & 2 & 350 & 0.3 & 3.9 & 0.844 \\
\hline 603 & 0.999 & 0.024 & 2 & 2 & 350 & 0.25 & 3.9 & 0.703 \\
\hline 604 & 0.999 & 0.015 & 2 & 2 & 350 & 0.2 & 3.9 & 0.563 \\
\hline 605 & 0.999 & 0.018 & 2 & 2 & 350 & 0.3 & 3.6 & 0.844 \\
\hline 606 & 0.999 & 0.06 & 1.5 & 2 & 350 & 0.7 & 3.9 & 1.969 \\
\hline 607 & 0.999 & 0.06 & 2 & 2 & 350 & 0.5 & 3.6 & 1.406 \\
\hline 608 & 0.999 & 0.024 & 2.2 & 2 & 350 & 0.6 & 3.6 & 1.688 \\
\hline 701 & 0.999 & 0.01 & 3 & 2 & 350 & 0.1 & 3 & 0.2813 \\
\hline 702 & 0.999 & 0.04 & 1.5 & 2 & 350 & 0.3 & 3.25 & 0.8438 \\
\hline 703 & 0.999 & 0.04 & 2 & 2 & 350 & 0.25 & 3.25 & 0.7031 \\
\hline 704 & 0.999 & 0.025 & 2 & 2 & 350 & 0.2 & 3.25 & 0.5625 \\
\hline 706 & 0.999 & 0.1 & 1.5 & 2 & 350 & 0.7 & 3.25 & 1.9688 \\
\hline 707 & 0.999 & 0.1 & 2 & 2 & 350 & 0.5 & 3 & 1.4063 \\
\hline 708 & 0.999 & 0.04 & 2.2 & 2 & 350 & 0.6 & 3 & 1.6875 \\
\hline 801 & 0.999 & 0.01 & 3 & 2 & 350 & 0.1 & 3 & 0.2813 \\
\hline 802 & 0.999 & 0.04 & 1.5 & 2 & 350 & 0.3 & 3.25 & 0.8438 \\
\hline 803 & 0.999 & 0.04 & 2 & 2 & 350 & 0.25 & 3.25 & 0.7031 \\
\hline 804 & 0.999 & 0.025 & 2 & 4 & 350 & 0.2 & 3.25 & 0.5625 \\
\hline 806 & 0.999 & 0.1 & 1.5 & 2 & 350 & 0.7 & 3.25 & 1.9688 \\
\hline 807 & 0.999 & 0.1 & 2 & 2 & 350 & 0.5 & 3 & 1.4063 \\
\hline 808 & 0.999 & 0.04 & 2.2 & 2 & 350 & 0.6 & 3 & 1.6875 \\
\hline 901 & 0.999 & 0.006 & 3 & 4 & 350 & 0.1 & 3.6 & 0.281 \\
\hline 902 & 0.999 & 0.024 & 1.5 & 4 & 350 & 0.3 & 3.9 & 0.844 \\
\hline 903 & 0.999 & 0.024 & 2 & 4 & 350 & 0.25 & 3.9 & 0.703 \\
\hline 906 & 0.999 & 0.06 & 1.5 & 4 & 350 & 0.7 & 3.9 & 1.969 \\
\hline 907 & 0.999 & 0.06 & 2 & 4 & 350 & 0.5 & 3.6 & 1.406 \\
\hline 908 & 0.999 & 0.024 & 2.2 & 4 & 350 & 0.6 & 3.6 & 1.688 \\
\hline
\end{tabular}




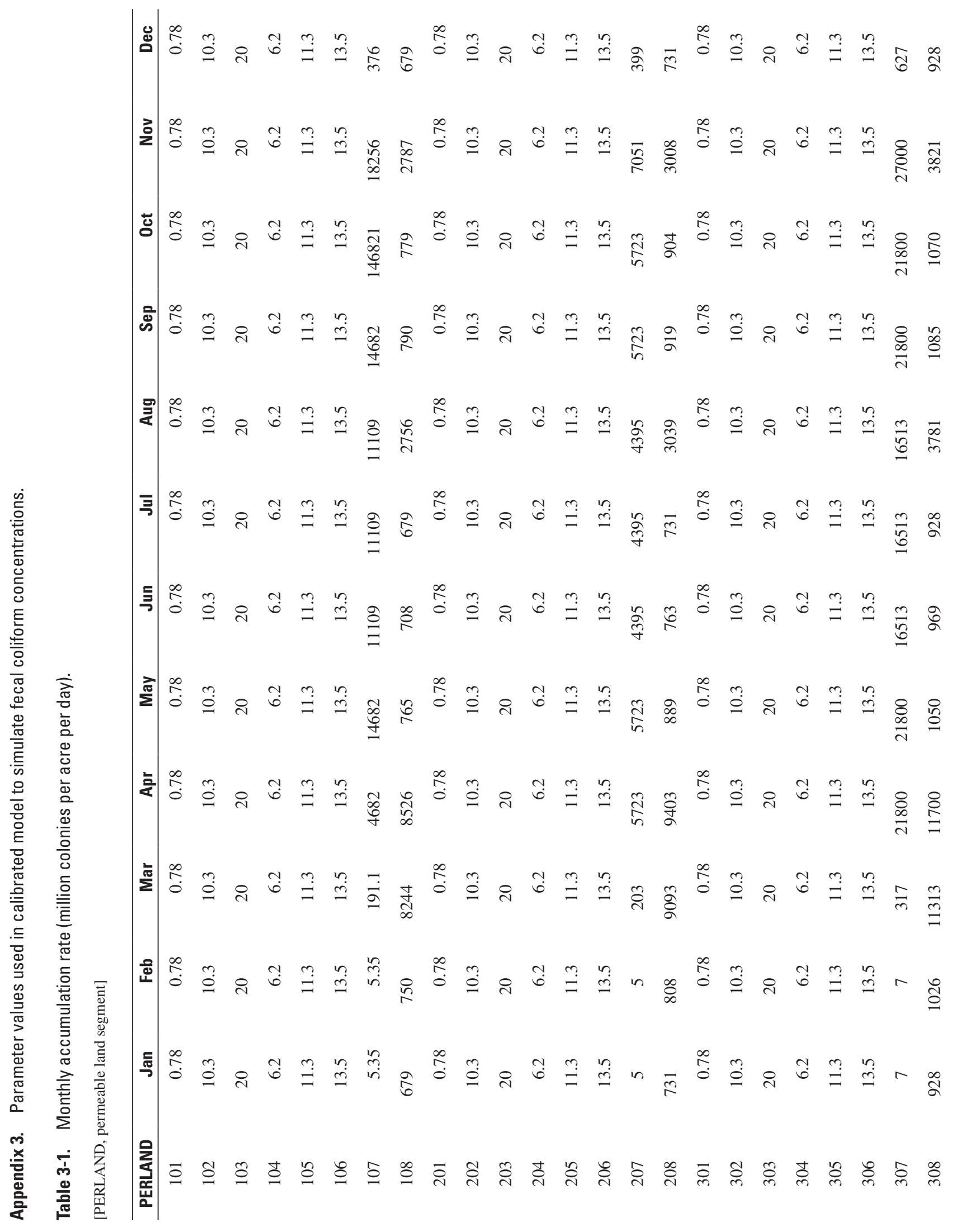




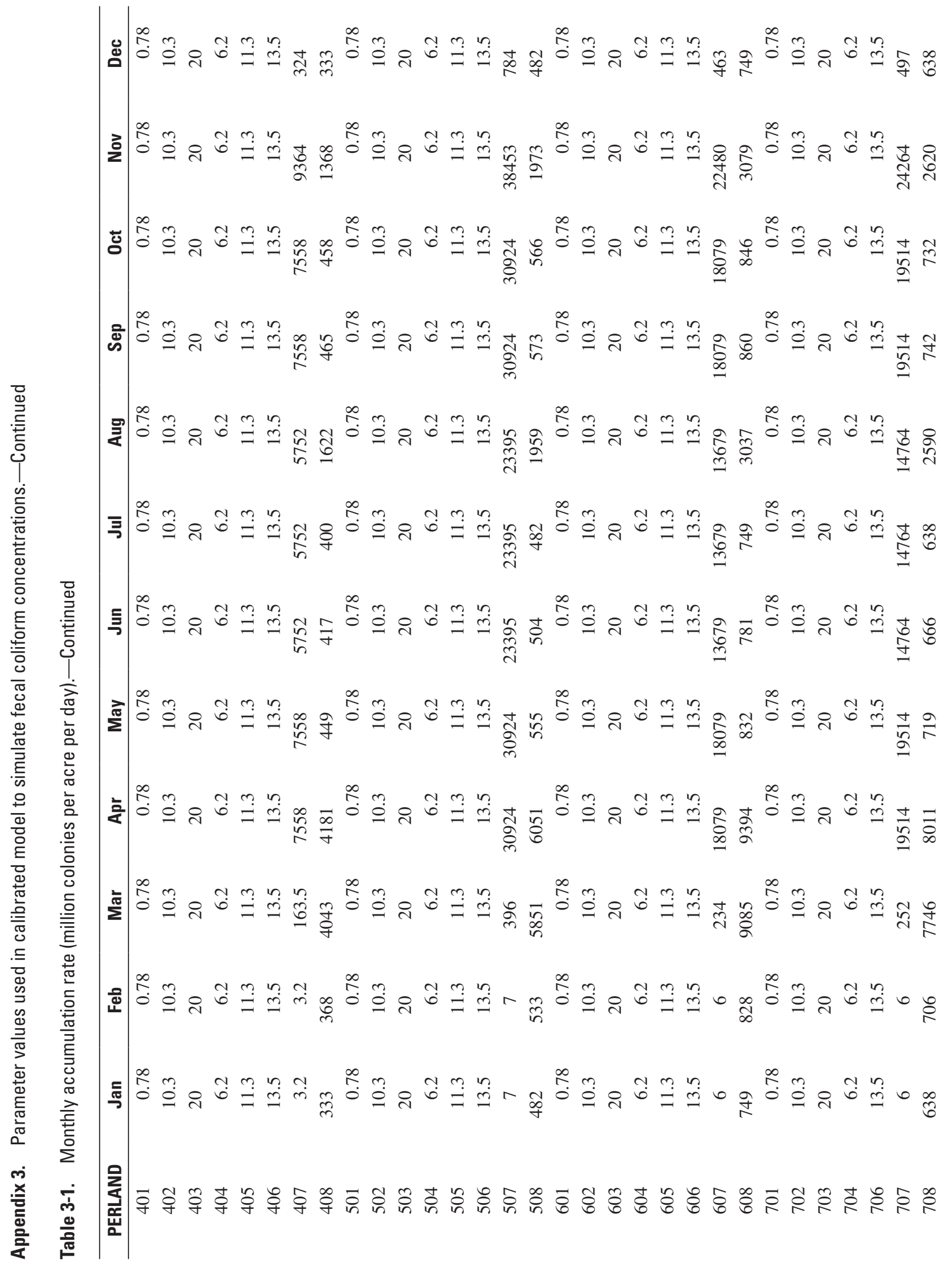




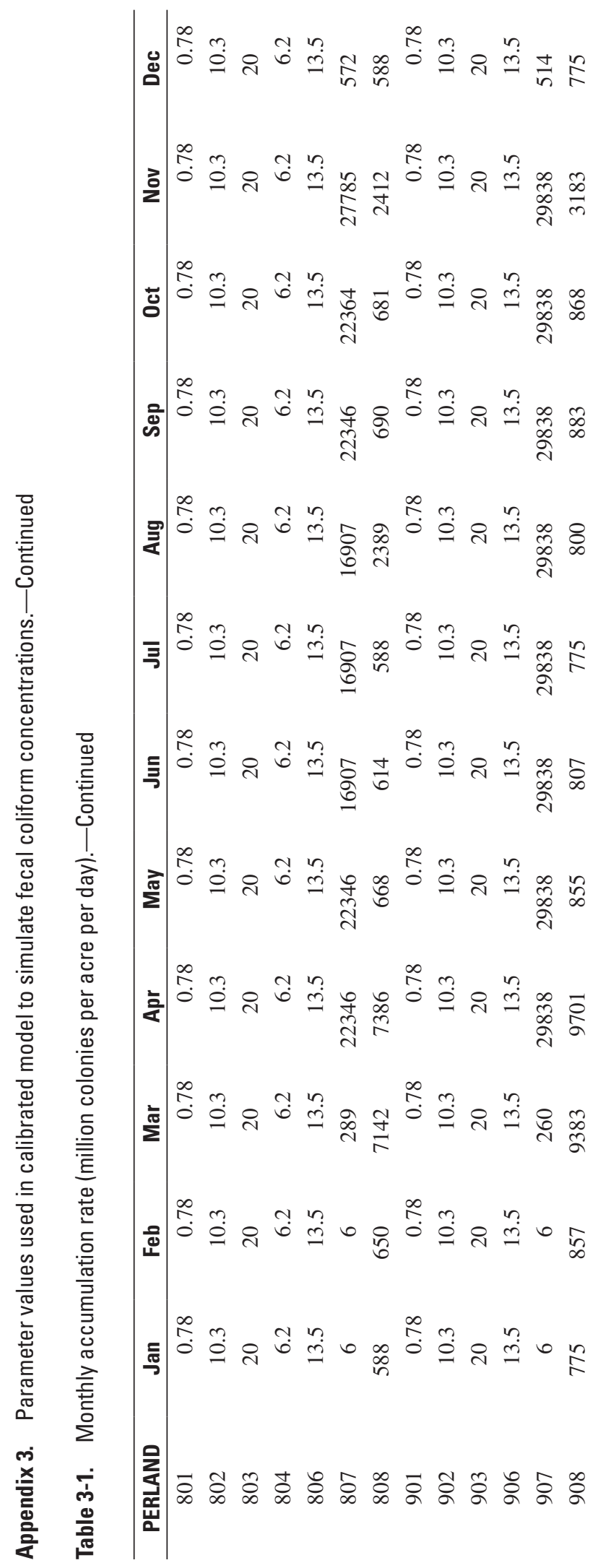




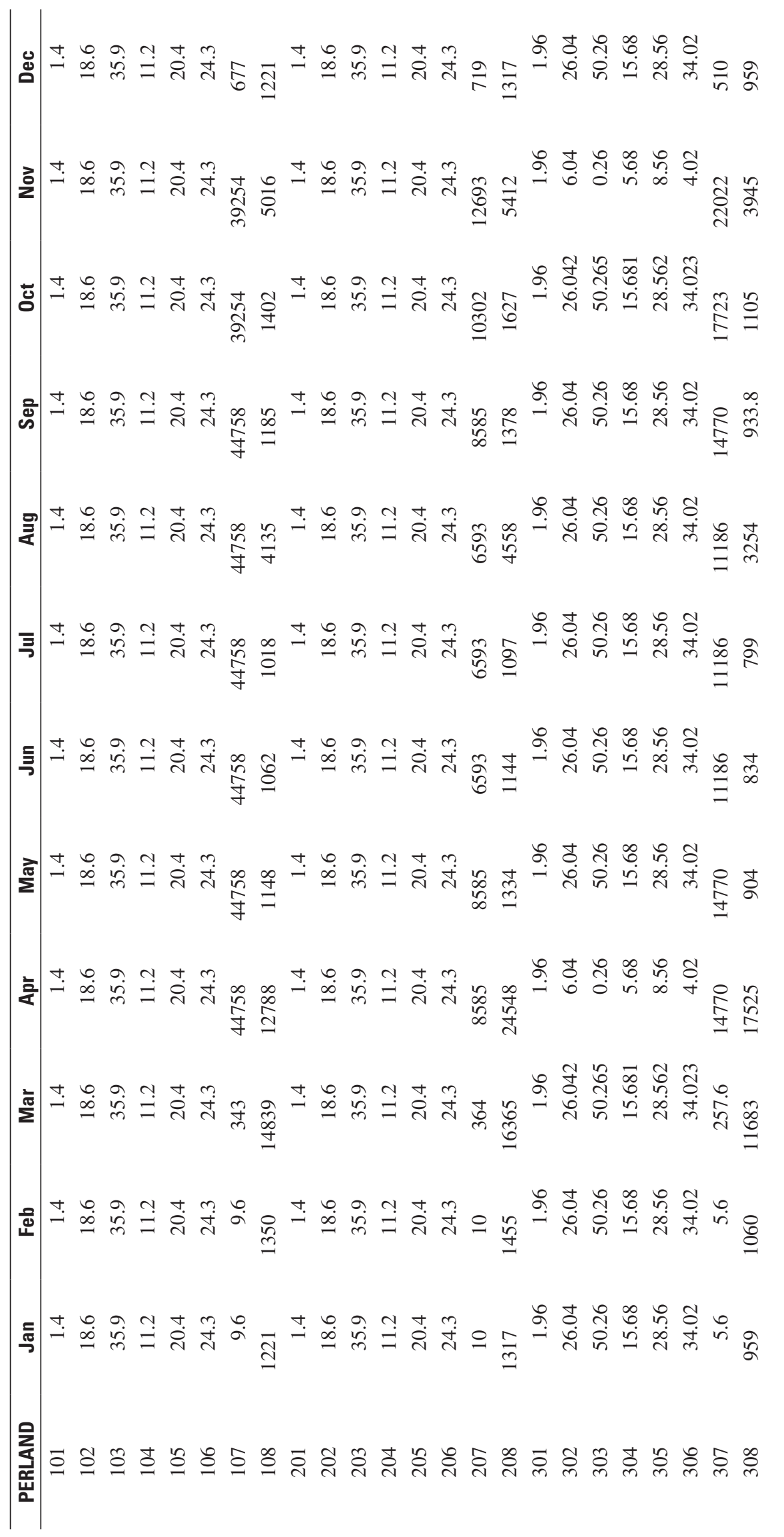




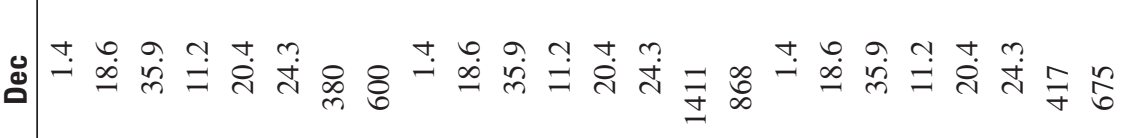

z)

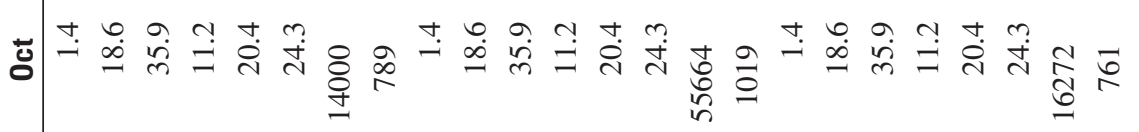

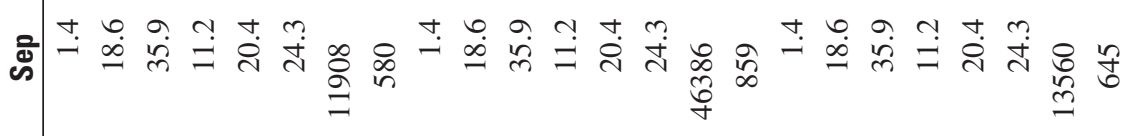

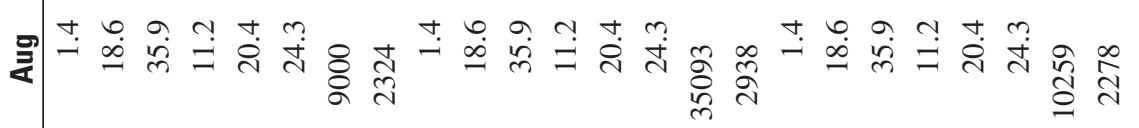

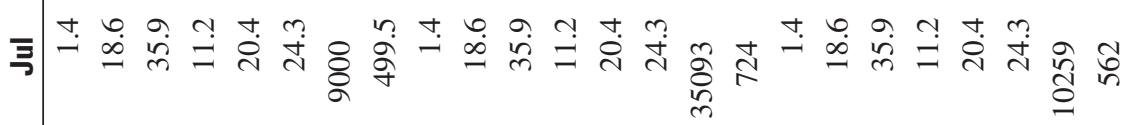

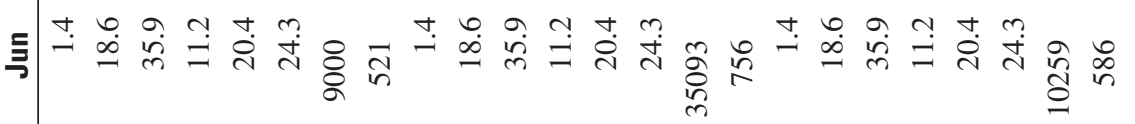

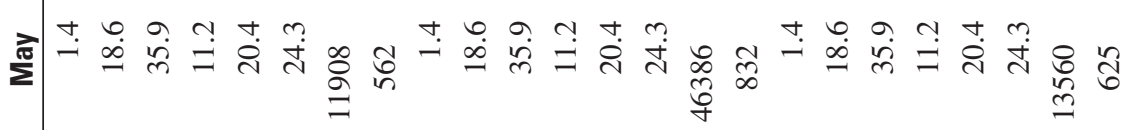

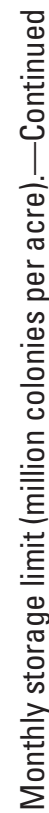

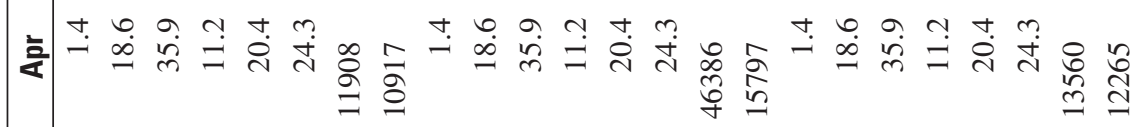

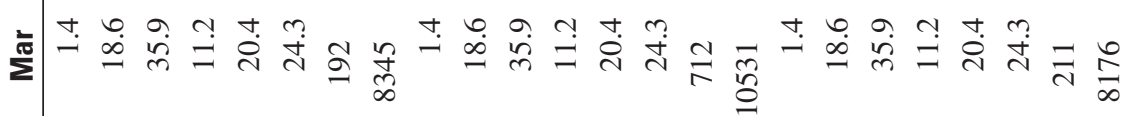

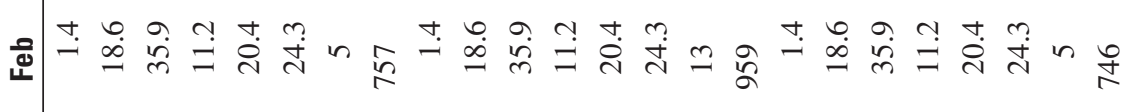

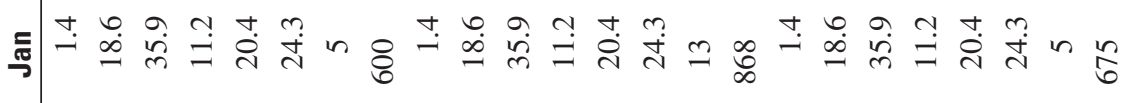

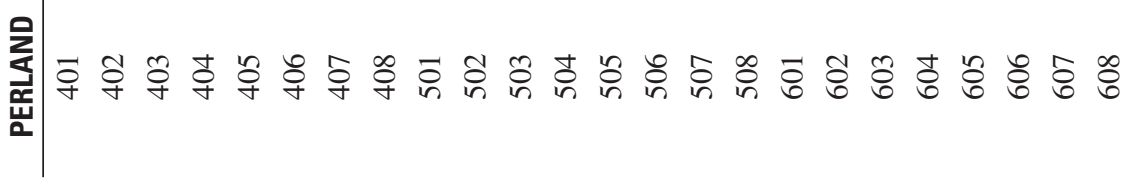




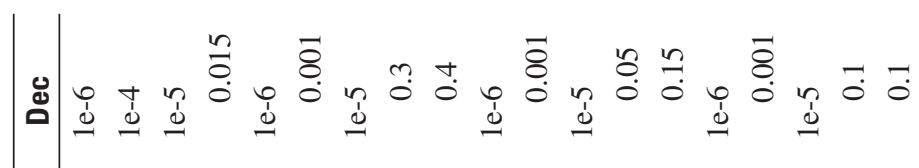

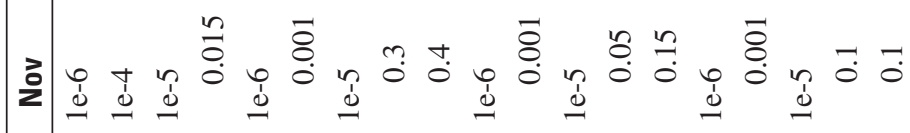

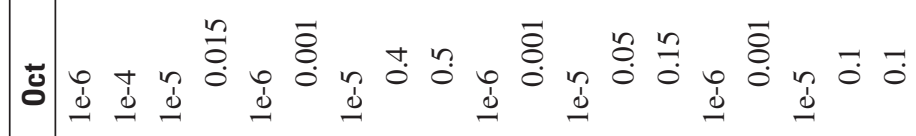

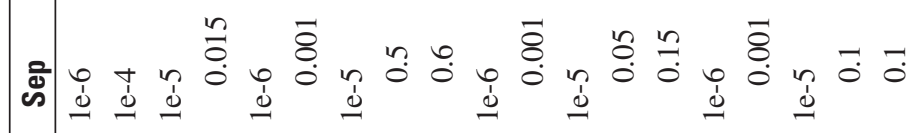

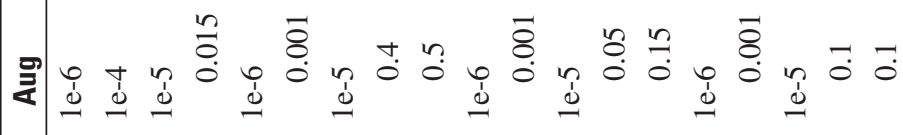

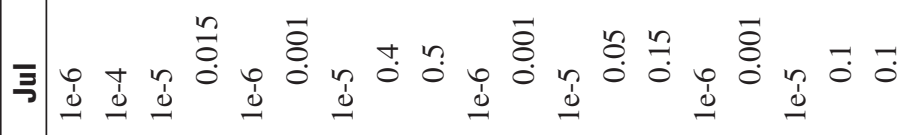

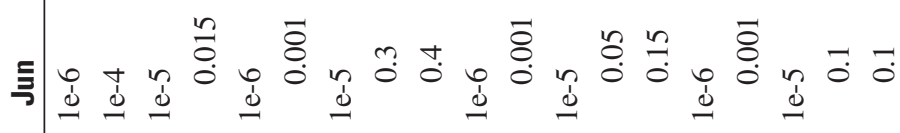

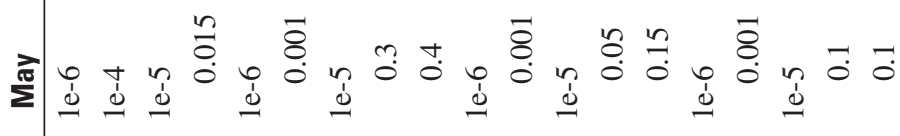

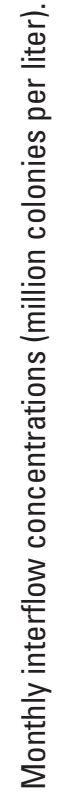

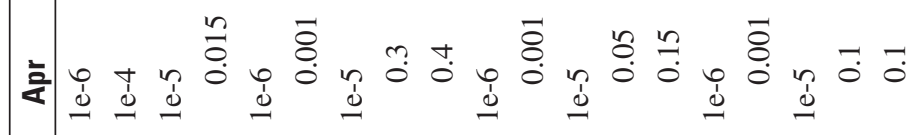

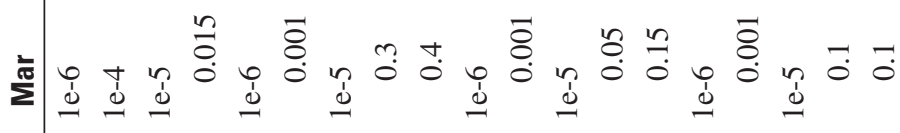

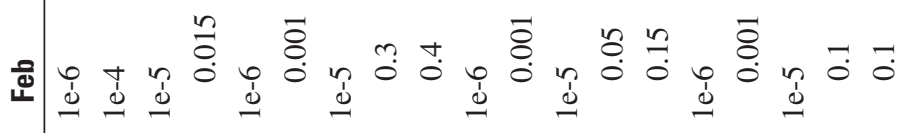

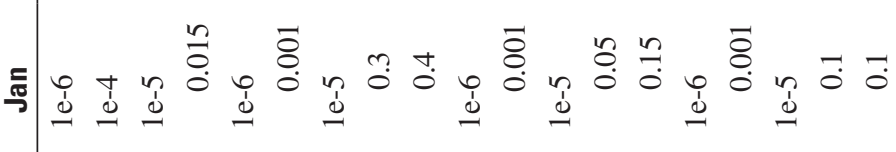

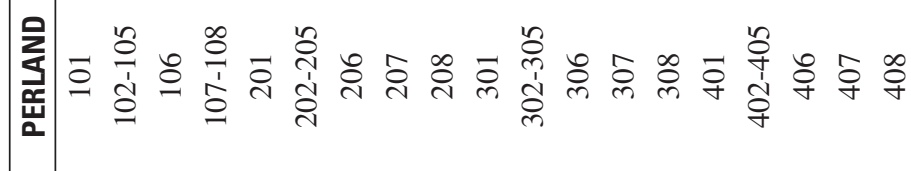




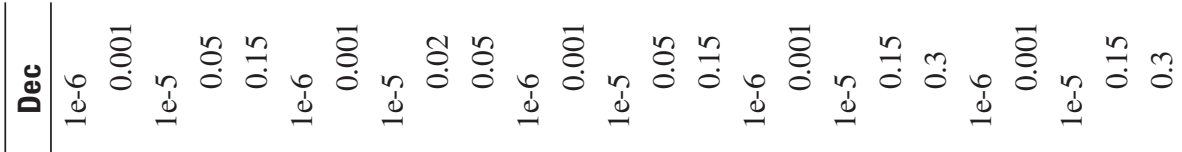

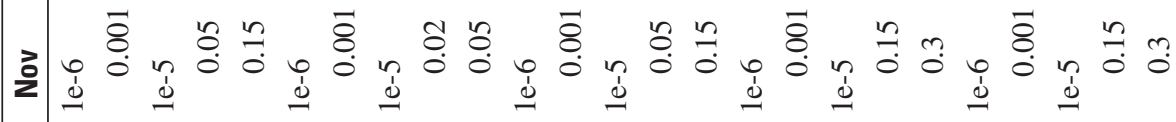

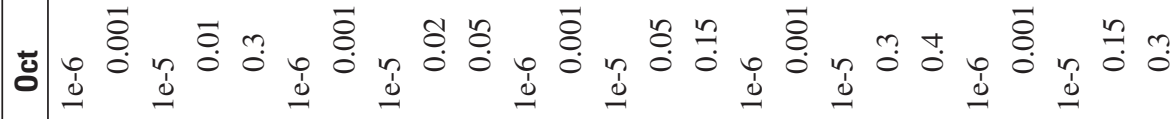

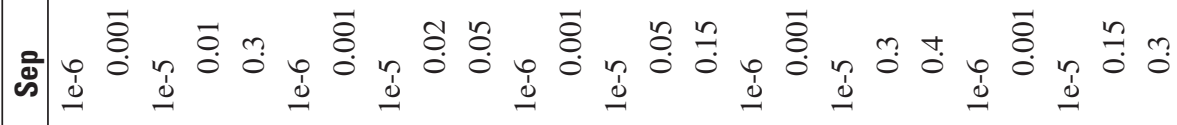

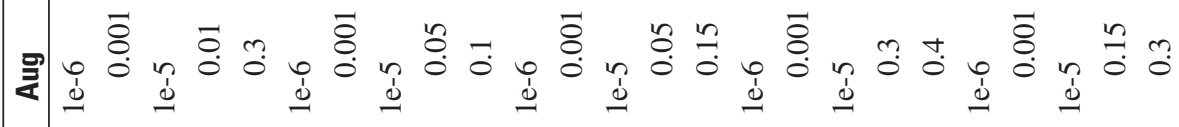

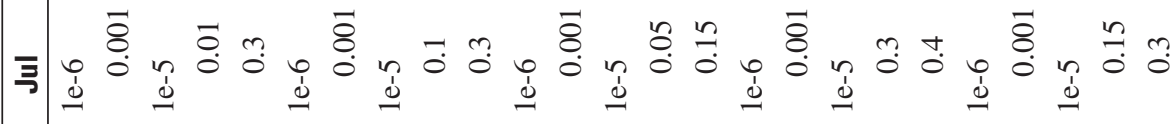

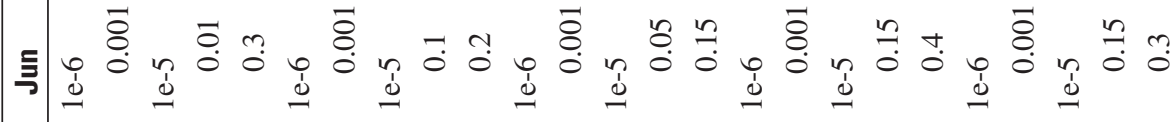

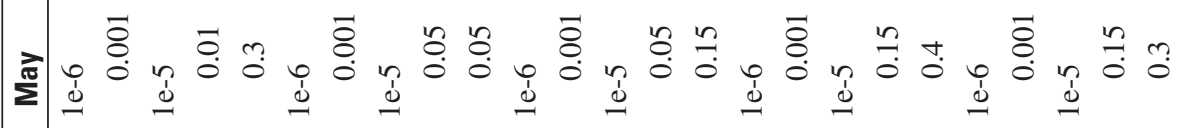

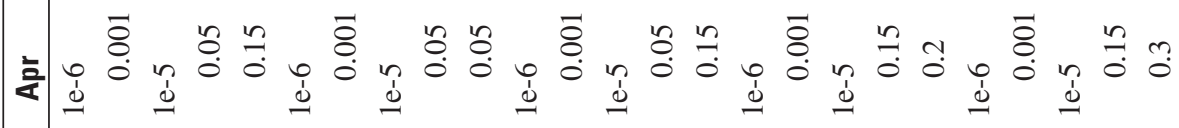

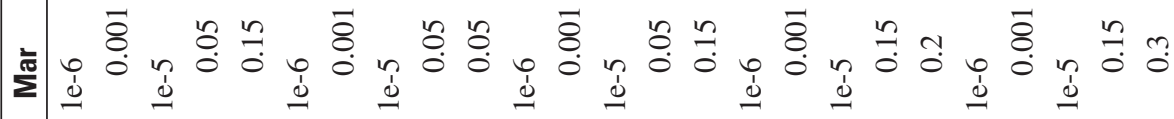

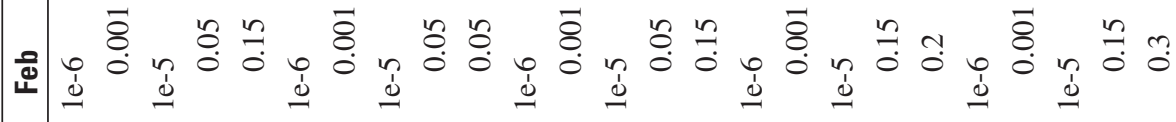

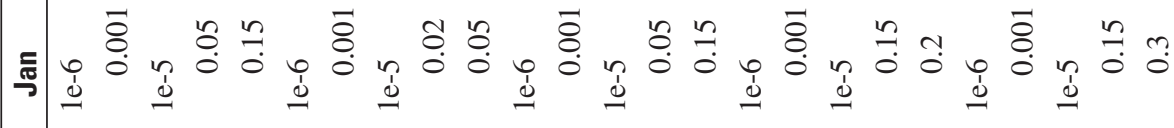

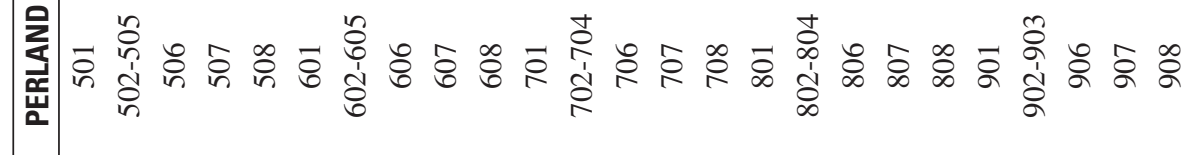


Appendix 3. Parameter values used in calibrated model to simulate fecal coliform concentrations. - Continued

Table 3-4. First order decay rate (per day).

[FSTDEC, first order decay rate]

\begin{tabular}{|c|c|c|c|c|c|c|c|}
\hline Subbasin & FSTDEC & Subbasin & FSTDEC & Subbasin & FSTDEC & Subbasin & FSTDEC \\
\hline 1 & 0.3 & 14 & 1.2 & 27 & 0.4 & 40 & 0.4 \\
\hline 2 & 0.4 & 15 & 0.7 & 28 & 1.2 & 41 & 0.3 \\
\hline 3 & 2.0 & 16 & 0.8 & 29 & 1.2 & 42 & 0.3 \\
\hline 4 & 0.3 & 17 & 1.2 & 30 & 1.2 & 43 & 1.2 \\
\hline 5 & 0.2 & 18 & 0.6 & 31 & 0.2 & 44 & 1.2 \\
\hline 6 & 0.3 & 19 & 1.2 & 32 & 0.4 & 45 & 0.7 \\
\hline 7 & 0.4 & 20 & 0.8 & 33 & 0.4 & 46 & 1.2 \\
\hline 8 & 0.4 & 21 & 0.8 & 34 & 1.2 & 47 & 1.2 \\
\hline 9 & 0.3 & 22 & 0.8 & 35 & 1.2 & 48 & 1.2 \\
\hline 10 & 0.25 & 23 & 1.2 & 36 & 0.8 & 49 & 1.2 \\
\hline 11 & 0.3 & 24 & 0.7 & 37 & 0.3 & 50 & 0.8 \\
\hline 12 & 0.2 & 25 & 1.2 & 38 & 0.4 & 51 & 0.2 \\
\hline 13 & 10000 & 26 & 0.2 & 39 & 0.4 & 52 & 1.2 \\
\hline
\end{tabular}


84 Simulation of Fecal Coliform and Nitrate in the Mad River Basin, Ohio

Appendix 3. Parameter values used in calibrated model to simulate fecal coliform concentrations.-Continued

Table 3-5. Susceptibility of fecal coliform to washoff (per inch).

[PERLAND, permeable land segment]

\begin{tabular}{|c|c|c|c|}
\hline PERLAND & & PERLAND & \\
\hline 101 & 11.5 & 601 & 11.5 \\
\hline $102-104$ & 2.6 & $602-604$ & 2.6 \\
\hline 105 & 2.3 & 605 & 2.3 \\
\hline 106 & 2.6 & 606 & 2.6 \\
\hline $107-108$ & 2.6 & $607-608$ & 2.6 \\
\hline 201 & 11.5 & 701 & 11.5 \\
\hline $202-204$ & 2.6 & $702-704$ & 2.6 \\
\hline 205 & 2.3 & 705 & 2.3 \\
\hline 206 & 2.6 & 706 & 2.6 \\
\hline $207-208$ & 2.6 & $707-708$ & 2.6 \\
\hline 301 & 11.5 & 801 & 11.5 \\
\hline $302-304$ & 2.6 & $802-804$ & 2.6 \\
\hline 305 & 2.3 & 805 & 2.3 \\
\hline 306 & 2.6 & 806 & 2.6 \\
\hline $307-308$ & 2.6 & $807-808$ & 2.6 \\
\hline 401 & 11.5 & 901 & 11.5 \\
\hline $402-404$ & 2.6 & $902-904$ & 2.6 \\
\hline 405 & 2.3 & 905 & 2.3 \\
\hline 406 & 2.6 & 906 & 2.6 \\
\hline $407-408$ & 2.6 & $907-908$ & 2.6 \\
\hline 501 & 11.5 & & \\
\hline $502-504$ & 2.6 & & \\
\hline 505 & 2.3 & & \\
\hline 506 & 2.6 & & \\
\hline $507-508$ & 2.6 & & \\
\hline
\end{tabular}




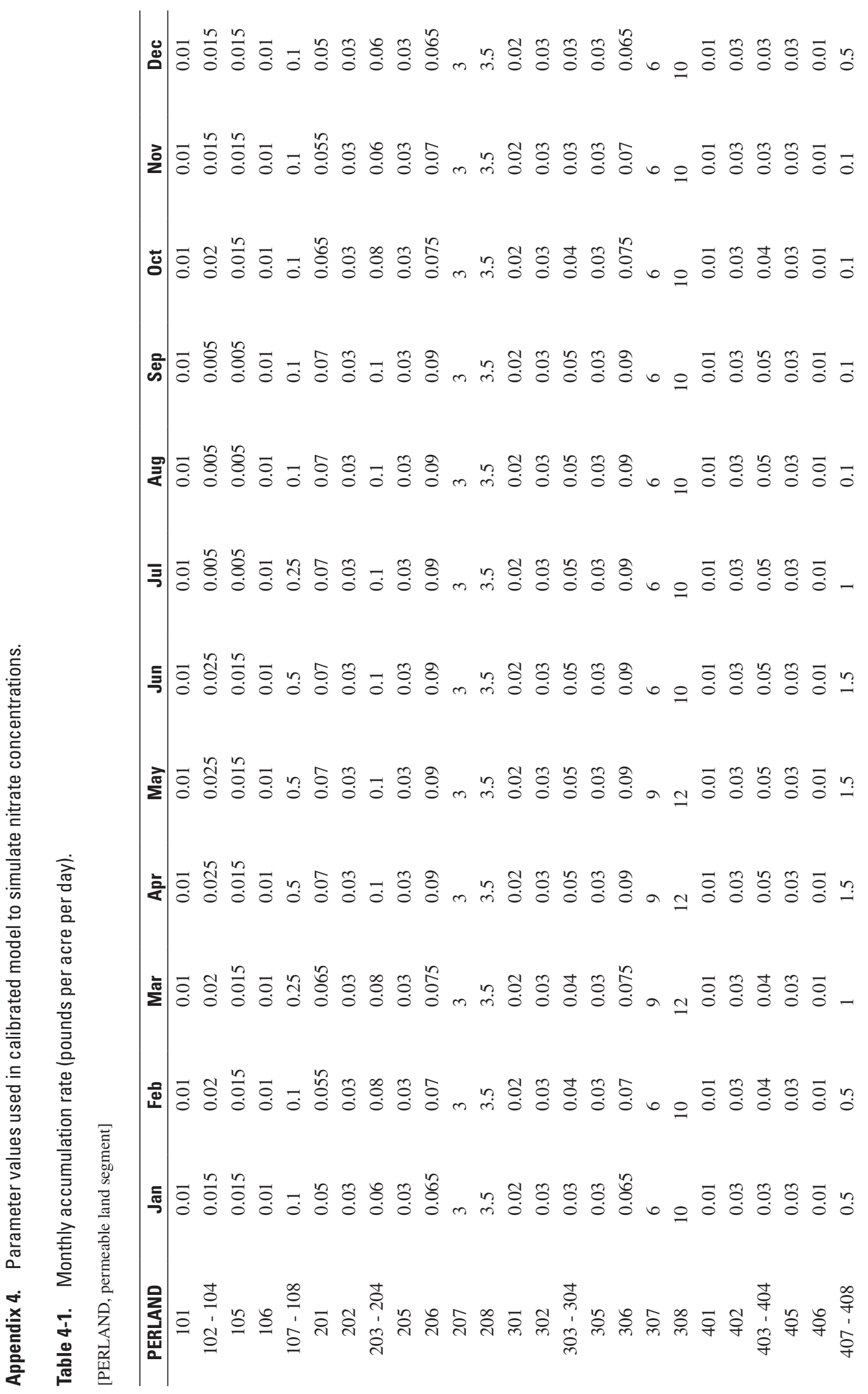




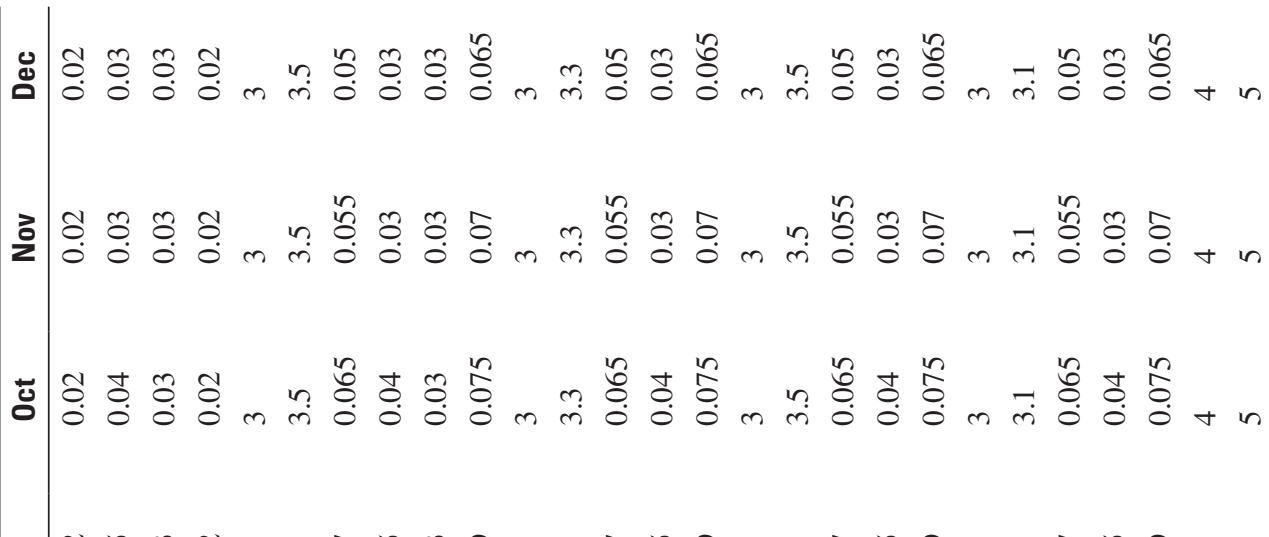

๗

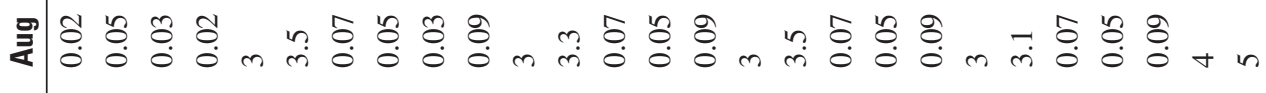

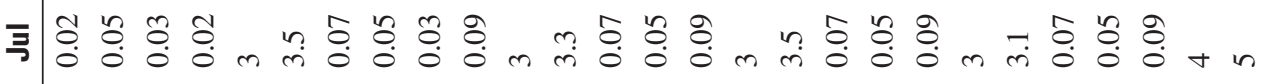

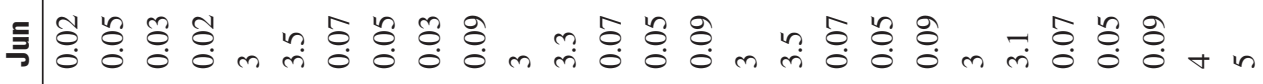

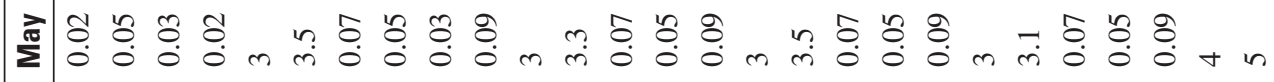

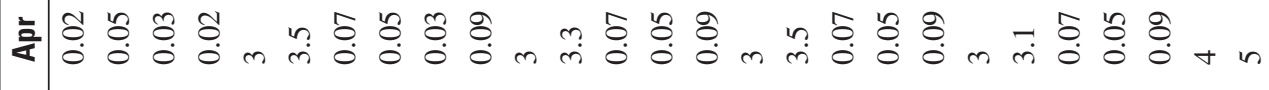

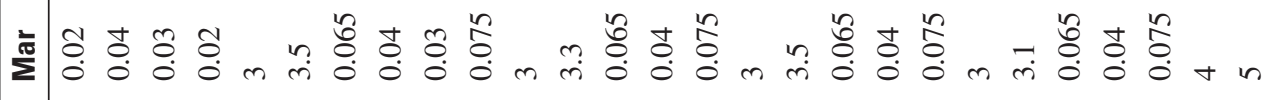

ॠ

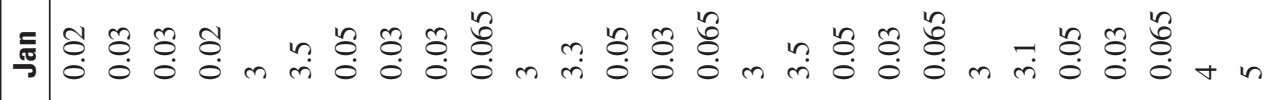

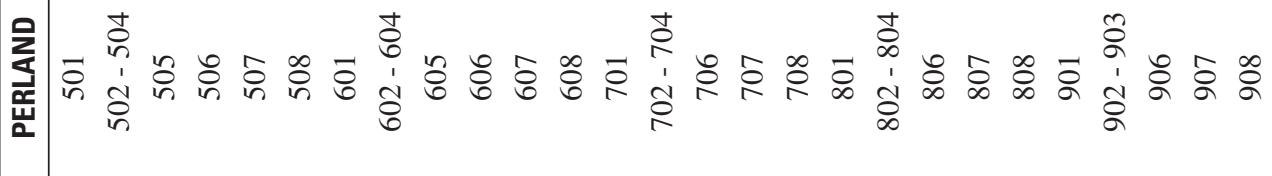




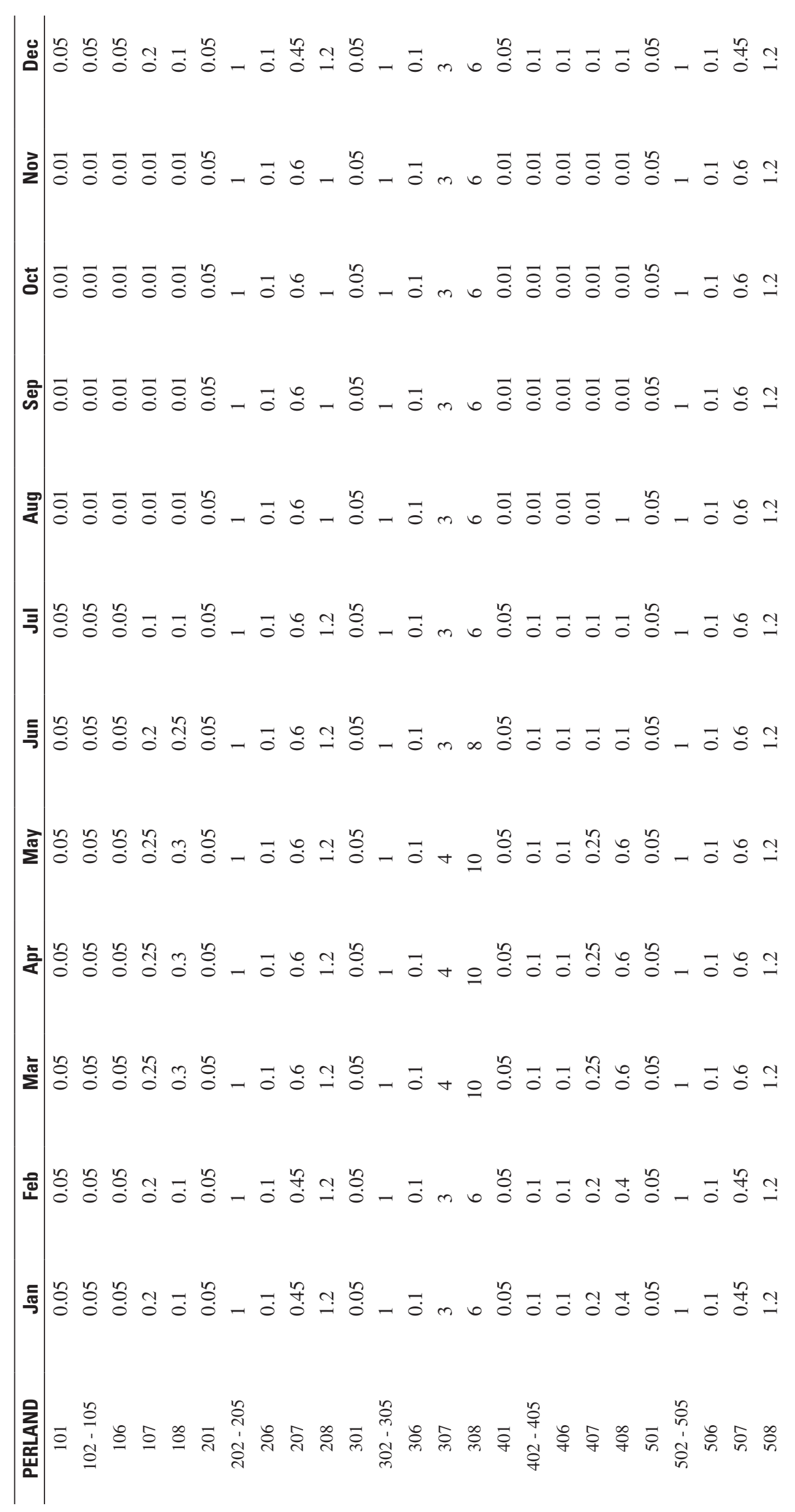


88 Simulation of Fecal Coliform and Nitrate in the Mad River Basin, Ohio

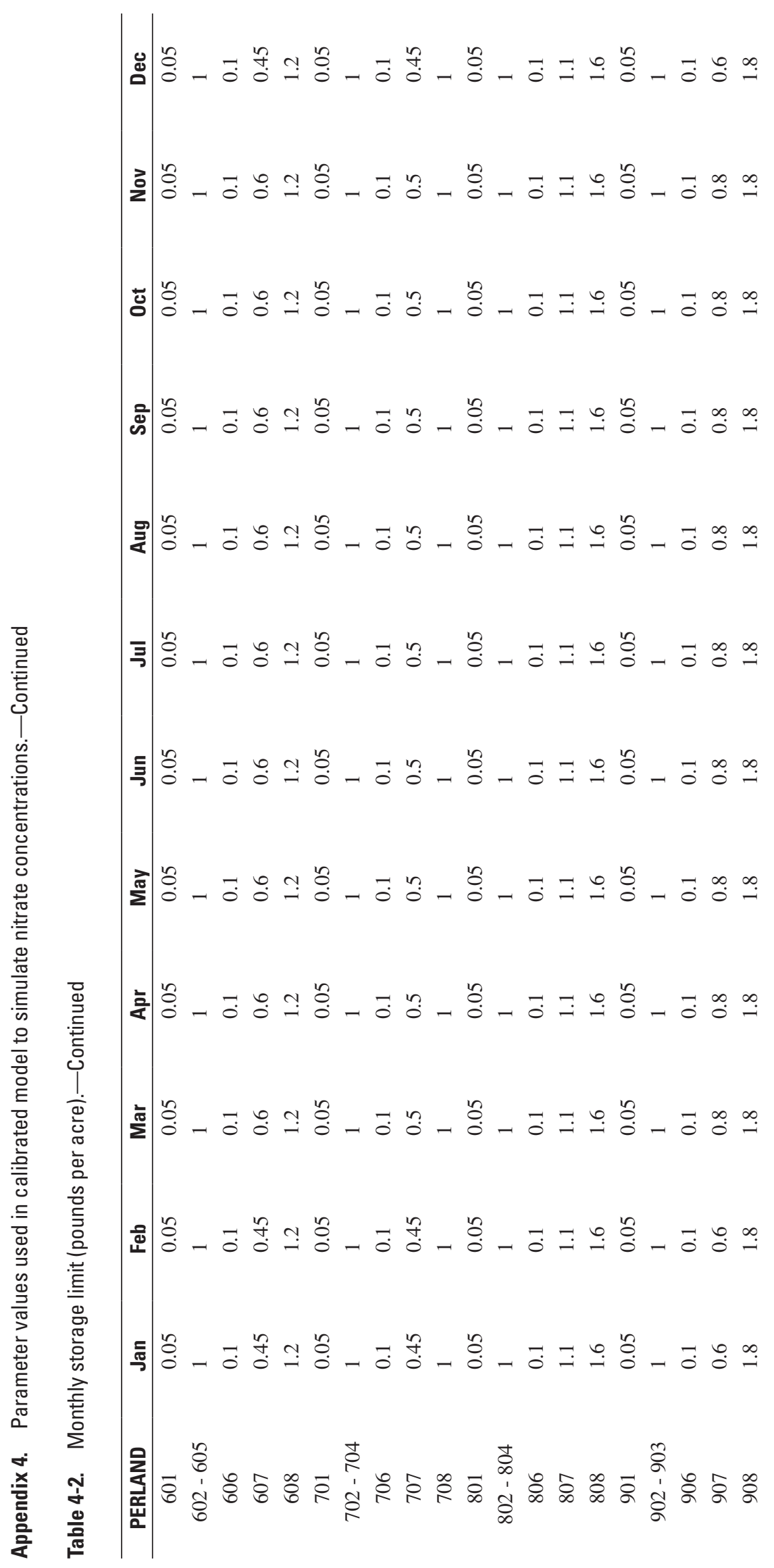


Appendixes

89

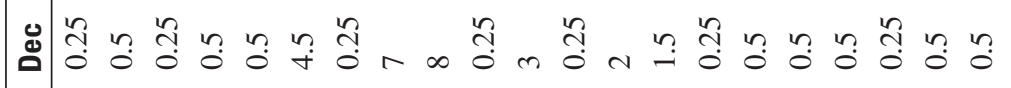

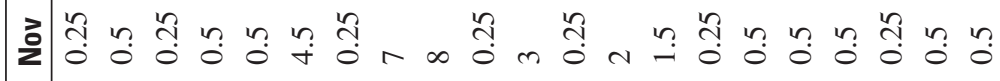

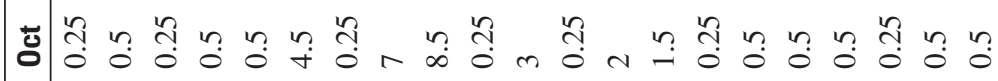

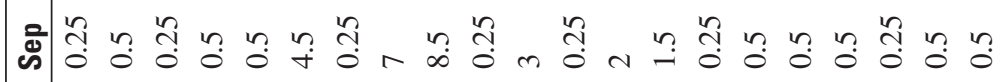

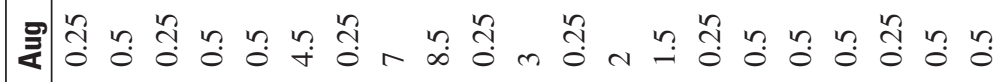

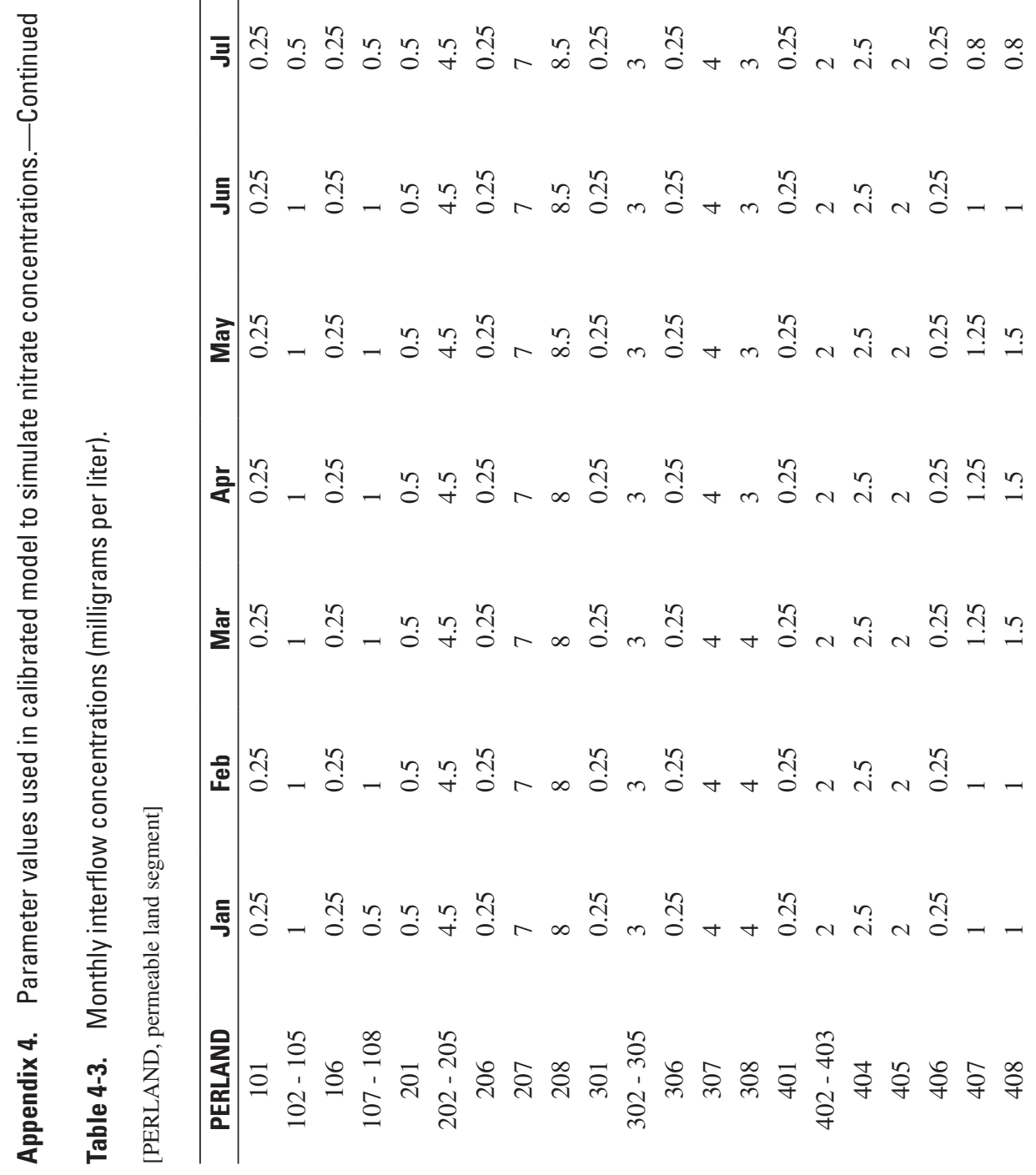




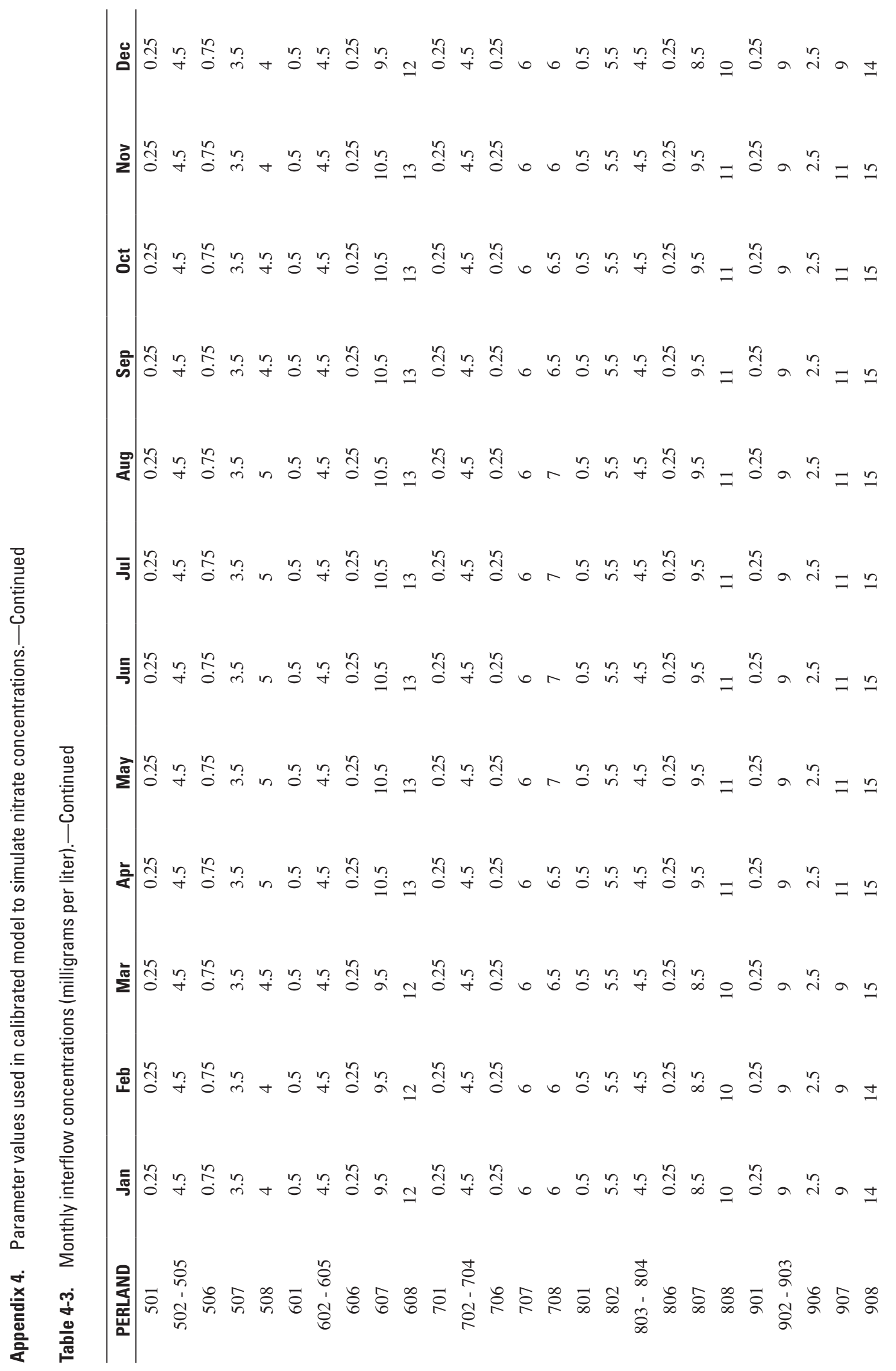




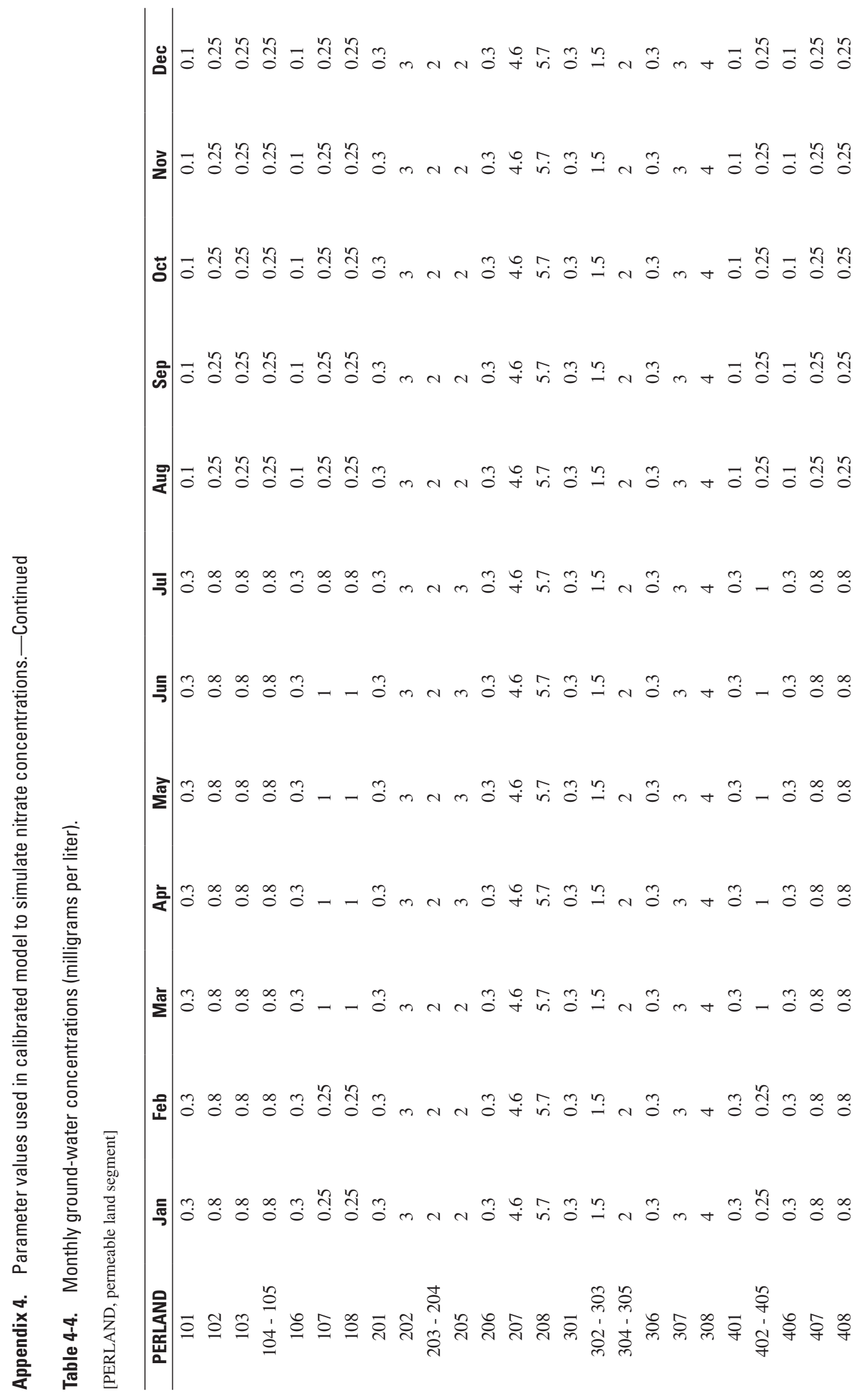


92

Simulation of Fecal Coliform and Nitrate in the Mad River Basin, Ohio

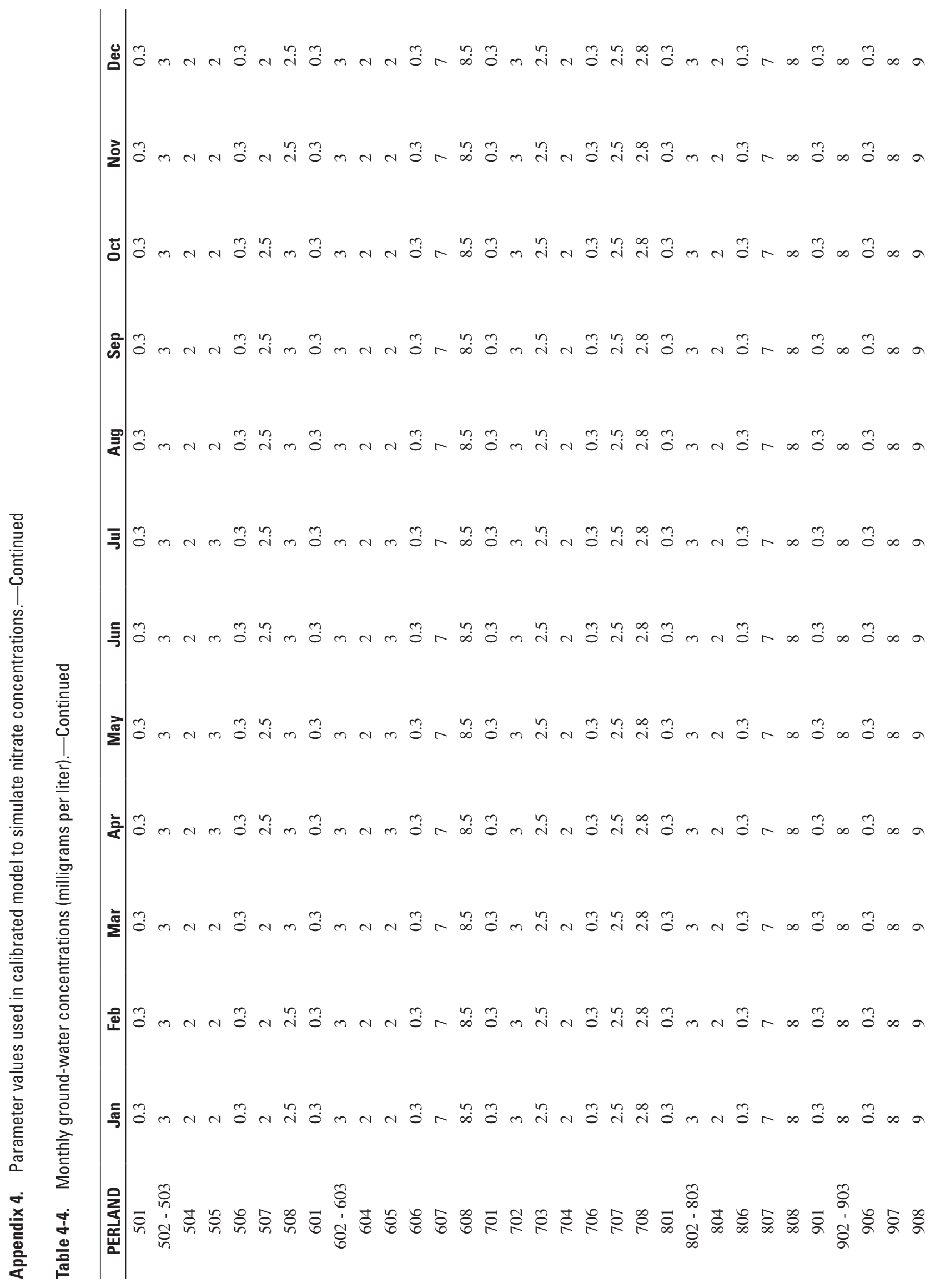


Appendix 4. Parameter values used in calibrated model to simulate nitrate concentrations.-Continued

Table 4-5. Susceptibility of nitrate to washoff (per inch).

[PERLAND, permeable land segment]

\begin{tabular}{|c|c|c|c|}
\hline PERLAND & & PERLAND & \\
\hline 101 & 11.5 & 601 & 11.5 \\
\hline $102-104$ & 2.6 & $602-604$ & 2.6 \\
\hline 105 & 2.3 & 605 & 2.3 \\
\hline 106 & 2.6 & 606 & 2.6 \\
\hline $107-108$ & 2.6 & $607-608$ & 2.6 \\
\hline 201 & 11.5 & 701 & 11.5 \\
\hline $202-204$ & 2.6 & $702-704$ & 2.6 \\
\hline 205 & 2.3 & 705 & 2.3 \\
\hline 206 & 2.6 & 706 & 2.6 \\
\hline $207-208$ & 2.6 & $707-708$ & 2.6 \\
\hline 301 & 11.5 & 801 & 11.5 \\
\hline $302-304$ & 2.6 & $802-804$ & 2.6 \\
\hline 305 & 2.3 & 805 & 2.3 \\
\hline 306 & 2.6 & 806 & 2.6 \\
\hline $307-308$ & 2.6 & $807-808$ & 2.6 \\
\hline 401 & 11.5 & 901 & 11.5 \\
\hline $402-404$ & 2.6 & $902-904$ & 2.6 \\
\hline 405 & 2.3 & 905 & 2.3 \\
\hline 406 & 2.6 & 906 & 2.6 \\
\hline $407-408$ & 2.6 & $907-908$ & 2.6 \\
\hline 501 & 11.5 & & \\
\hline $502-504$ & 2.6 & & \\
\hline 505 & 2.3 & & \\
\hline 506 & 2.6 & & \\
\hline $507-508$ & 2.6 & & \\
\hline
\end{tabular}




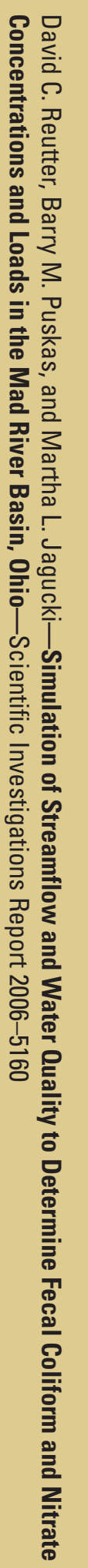

6 Printed on recycled paper 